\title{
UNREGULABLE DEFENSES AND THE PERILS OF SHAREHOLDER CHOICE
}

\author{
JENNIFER ARLEN $^{\dagger} \&$ ERIC TALLEY $^{\dagger+}$
}

\begin{abstract}
A significant debate rages within corporate law scholarship as to whether shareholders or managers should be granted authority over the tender offer process once $a$ bid is imminent. Both sides generally agree that the issue depends on whether shareholders are capable of exercising informed choice over takeover bids. Supporters of managerial veto power contend that the arguments favoring professional management of publicly held firms carry over into the tender offer context. Proponents of shareholder choice, on the other hand, argue that shareholders can act on their own behalf in the special circumstances surrounding contests for corporate control.

This Article challenges the premise that the case for shareholder choice turns principally on whether shareholders are capable of making informed choices. It argues that adopting a strong shareholder choice regime may be value reducing even if shareholders can effectively manage the firm post-bid. In particular, a shareholder choice rule would give managers an incentive to search for alternative defenses not practicably regulable by any legal regime-ones that may impose greater costs on the firm than existing defenses. We demonstrate (a) that a number of such unregulable, value-reducing defenses exist, (b) that managerial threats to use them are credible under plausible conditions, and (c) that their use would be difficult or impossible for courts to regulate. Furthermore, we find empirical support for these hypotheses. Consequently, we conclude that an immutable, one-sizefits-all shareholder choice rule is unlikely to improve shareholders' welfare.
\end{abstract}

† Norma Z. Paige Professor of Law, New York University Law School. Contact at Jennifer.Arlen@nyu.edu.

${ }^{t t}$ Professor of Law, University of Southern California Law School, and Senior Economist, RAND Corporation Institute for Civil Justice. Contact at etalley@law.usc. edu.

We would like to thank the following for their helpful comments and discussions: William Allen, Elizabeth Arlen, Bernard Black, Phil Bond, Andrew Brownstein, William Carney, Stephen Choi, John Coates, Isaac Core, Robert Daines, Paul Davies, Jill Fisch, Jesse Fried, Stephen Fraidin, Ronald Gilson, Gillian Lester, Joseph Hall, Henry Hansmann, Marcel Kahan, Ehud Kamar, David Katz, Reinier Kraakman, Gillian Lester, Randy Picker, Dan Prentice, Robert Reville, Ed Rock, Helen Scott, Robert Sitkoff, James Spindler, Ethan Stone, George Triantis, Elaine Ziff, and the participants at the University of Pennsylvania Law Review Symposium on Corporate Control Transactions and at seminars at the University of Chicago Law School, Georgetown Law Center, Kirkland \& Ellis LLP, New York University Stern School of Business, and the Washington University School of Law. We also would like to thank our research assistants Jeremy Dorin, Mary Quach, Nishal Ramphal, and Matthew Wargin, as well as Elizabeth Evans, the New York University reference librarian. The conclusions of this paper do not necessarily represent the views of the RAND Corporation or any of the lawyers whom we consulted in our research. All errors are our own. 
INTRODUCTION

I. THE DOMAIN OF SHAREHOLDER CHOICE.......................................588

A. Advantages of Managerial Control of Publicly Held Firms..................588

B. The Case for Shareholder Control over Tender Offers .......................590

C. Taxonomy of Defensive Measures..................................................593

1. Pre- Versus Post-Bid Defenses................................................594

2. Pure Versus Embedded Defenses .........................................596

D. The Importance of the Unexamined Fourth Quadrant ......................599

1. Unregulable Defenses .........................................................599

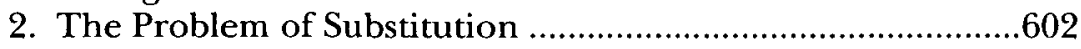

II. AVAILABILITY OF PRE-BID EMBEDDED DEFENSES..............................65

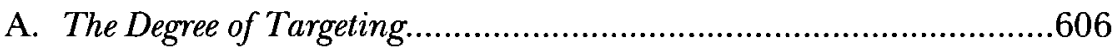

B. Retaining Managerial Control over Tender Offers............................608

1. Targeted Defenses Supported by Shareholder Approval .......608

2. Targeted Defenses Not Requiring Shareholder Approval .....612

C. Impediments to All Changes of Control.............................................614

1. Change of Control Provisions in Third-Party Agreements.....614

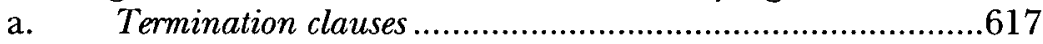

b. Penalty provisions ..........................................................619

2. Change of Control Provisions Under Shareholder Choice....623

D. Pre-Bid Measures Granting Managers Private Benefits .....................626

III. THE INCENTIVE TO EMPLOY EMBEDDED DEFENSES .........................628

A. The Costs and Benefits to Managers of Blanket Defenses....................629

B. Managers' Incentives Under Managerial Choice ...............................630

C. Managers' Incentives Under Shareholder Choice ...............................631

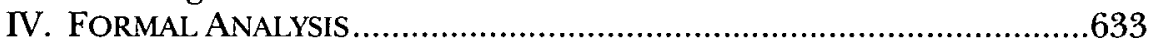

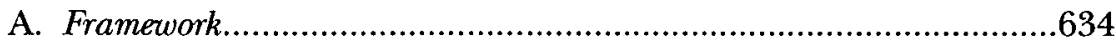

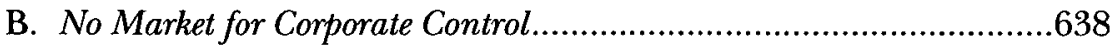

C. Market for Corporate Control .....................................................641

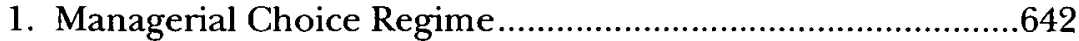

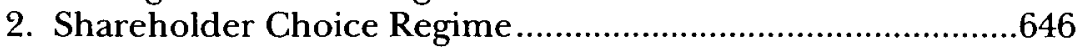

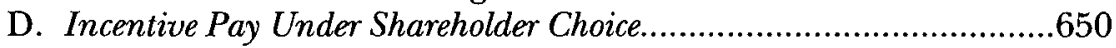

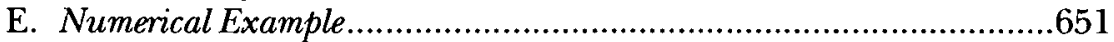

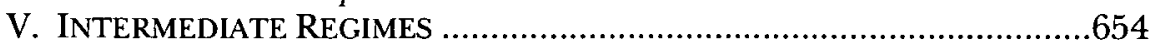

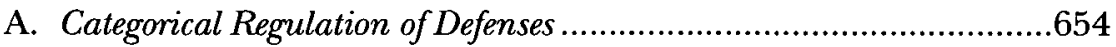

B. Strategic Uncertainty Regarding Managerial Authority .....................657

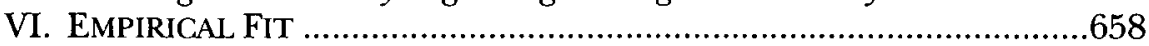

A. Shareholder Attitudes Toward Managerial Choice............................658

B. Evidence on Defenses and Executive Compensation ............................661

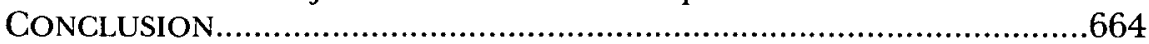




\section{INTRODUCTION}

In the years since the takeover wave of the 1980s, managers of public corporations have developed increasingly successful strategies for deterring or defeating unwanted tender offers. Although courts initially viewed defensive strategies (such as poison pills, staggered boards, and dual class stock capitalization) with suspicion, over time they have embraced a significantly more deferential approach to antitakeover defenses. Indeed, under current law, managers of Delaware corporations' face few impediments when erecting defenses that deter unwanted acquisitions, ${ }^{2}$ provided that they are not selling control of the firm. ${ }^{3}$ All the while, shareholders generally have not attempted to counter this jurisprudential trend by imposing ex ante limitations on managers' control over tender offers. ${ }^{4}$

Nevertheless, many corporate law scholars view the extant regime with a mixture of skepticism and alarm, arguing that it has exacerbated the agency cost problems endemic to publicly owned firms. Directors and officers, ${ }^{5}$ they claim, systematically collaborate to employ antitakeover defenses that deter hostile acquisitions (which portend managerial turnover), while simultaneously encouraging friendly bids (which confer substantial private benefits on incumbents). ${ }^{6}$

${ }^{1}$ Companies incorporated in Delaware accounted for nearly three-fifths of the Fortune 500 publicly listed companies in 2002. See Del. Div. of Corps., Why Choose Delaware As Your Corporate Home?, Homepage, at http://www.state.de.us/corp/default. shtml (last updated Nov. 3, 2003) (reporting that "more than $50 \%$ of all U.S. publicly traded companies and 58\% of the Fortune 500" have chosen Delaware as their legal home).

${ }^{2}$ These categorical strategies often are dubbed "just say no" defenses. See Paramount Communications, Inc. v. Time, Inc., 571 A.2d 1140, 1151 (Del. 1990) ("The adoption of structural safety devices alone does not trigger Revlon."); see also Unitrin, Inc. v. Am. Gen. Corp., 651 A.2d 1361, 1390 (Del. 1995) (concluding that, if defensive measures, "individually and collectively . . . were proportionate to the threat" received from the hostile acquirer, then the board's adoption of the measures "is entitled to review under the traditional business judgment rule").

${ }^{3}$ By contrast, managers generally are prohibited from playing favorites among bidders once a control change of the company has become inevitable. See, e.g., Paramount Communications, Inc. v. QVC Network Inc., 637 A.2d 34, 45 (Del. 1994) (" $[\mathrm{T}]$ he directors must decide which alternative is most likely to offer the best value reasonably available to the stockholders."); Revlon, Inc. v. MacAndrews \& Forbes Holdings, Inc., 506 A.2d 173, 184 (Del. 1986) ("[W] hen bidders make relatively similar offers, or dissolution of the company becomes inevitable, the directors cannot fulfill their ... duties by playing favorites with the contending factions.").

${ }^{4}$ See infra Part VI.A (discussing the empirical data on shareholders' attitudes toward managerial choice).

${ }^{5}$ In what follows, we shall refer to directors and officers collectively as "managers."

${ }^{6}$ See Lucian Arye Bebchuk, John C. Coates IV \& Guhan Subramanian, The Powerful 
Managerial freedom to adopt defenses thereby hurts nonmanagerial shareholders, both by removing the disciplinary effect of potential hostile offers and by enabling managers to appropriate private gains from acquisitions that rightfully belong to all shareholders.

Accordingly, skeptics of managerial discretion argue that shareholders should have ultimate authority to choose among tender offers, on the grounds that, all things considered, shareholders' judgment in such contexts is ultimately more reliable than that of professional (but irremediably conflicted) managers. ${ }^{8}$ Although the universe of "shareholder choice" proposals is relatively varied, all share at least a few common, prescriptive features: most notably, they propose that shareholders should have authority over managers' defensive actions when shareholders have sufficient incentives and capacity to choose between the managers' preferred action and the hostile bid. The most aggressive shareholder choice proposals assume that, post-bid, shareholders have sufficient incentives and capacity to evaluate any business decision affecting takeovers, and thus conclude that shareholders should be granted authority to overturn managers' takeover defenses when either a bid has already emerged or when the firm adopts a policy whose sole purpose is to grant managers control over hostile tender offers. ${ }^{9}$

At the same time, most serious shareholder choice proponents stop short of extending their argument to all decisions that are currently undertaken by managers. Rather, they accept the foundational precept (reflected in the "business judgment rule") that publicly held firms maximize value when managers control ordinary business decisions since shareholders have little incentive or ability to obtain the information necessary to make such routine, day-to-day decisions. ${ }^{10}$

Antitakeover Force of Staggered Boards: Theory, Evidence and Policy, 54 STAN. L. REv. 887, 928 (2002) (finding empirical support for the strength of poison pills used in combination with "effective staggered boards" as an antitakeover defense).

${ }^{7}$ See infra Part I.B (discussing the views of leading proponents of shareholder choice).

${ }^{8}$ See infra Part I.B (presenting the view of some scholars that, in the informationrich context of a takeover bid, shareholders are better decision makers than managers who are defending the status quo).

${ }^{9}$ E.g., Lucian Arye Bebchuk, The Case Against Board Veto in Corporate Takeovers, 69 U. CHI. L. REV. 973, 1027-28 (2002) (arguing that shareholders should be permitted to vote on whether to pursue a tender offer, even in the face of an alternative plan by the board that keeps the firm free-standing).

${ }^{10}$ E.g., id. at 996 (asserting that letting shareholders of a publicly traded company make ordinary business decisions is "not a viable option"). Indeed, even when an ordinary decision entails a conflict of interest, scholars generally prefer to vest 
Consequently, much of the debate over shareholder choice is thought to turn on whether, all things considered, shareholders can be expected to exercise informed choice within the specific nexus of activity related to tender offers. Underlying this fundamentally empirical question, however, is a deeper logical proposition: that the demonstrated decision-making capacity of shareholders is both a necessary and sufficient condition to establish the superiority of shareholder choice relative to the status quo of managerial control. ${ }^{11}$

This Article refutes that proposition. In particular, we show that even when shareholders can effectively assess and react to hostile bids, shareholder choice may not be the optimal legal policy. Indeed, allowing informed shareholders to exercise control over tender offers may, ironically, make shareholders worse off than they would be under the status quo, where self-interested managers effectively choose among takeover options.

Our argument hinges on recognizing that a shareholder choice regime may significantly affect how managers govern the firm ex ante. While shareholder choice limits the defenses available to managers, it does not reduce managers' desire to deter hostile bids. If anything, an effective shareholder choice regime enhances managerial incentives to deter acquisitions by suppressing hostile offers. ${ }^{12}$ Consequently, under shareholder choice, managers have an incentive to search for effective defenses that are not plausibly susceptible to legal regulation of any stripe. ${ }^{13}$ In the extreme, managers may be willing to

decision-making authority in outside directors. See, e.g., FRANK H. EASTERBROOK \& DANIEl R. Fischel, THE ECONOMIC STRUCTURE OF CORPORATE LAW 104 (1991) ("Disinterested directors . . . are proxies for investors and can be cheap substitutes for liability rules in assuring contractual performance."). By contrast, in the case of tender offers, many corporate law scholars advocate shareholder authority even when the firm has a majority of outside directors. See infra Part I.B (discussing leading shareholder choice proposals, none of which predicate the proposed scope of shareholder authority on the composition of the board).

"See infra Parts I.A-B (discussing the debate over shareholder choice).

${ }^{12}$ In this Article, we focus on the strongest shareholder choice regimes that grant shareholders ultimate authority to determine the fate of all pure and post-bid defenses. See, e.g., Bebchuk, supra note 9 , at 976 (arguing that "once a mechanism that ensures an undistorted choice by shareholders is in place, the board should not be able to veto an acquisition beyond the period necessary for preparing alternatives for shareholder consideration"). For a discussion of intermediate regimes, see infra Part V.

${ }^{13}$ For a discussion of other arguments favoring managerial choice beyond those offered here, see, for example, Marcel Kahan \& Edward Rock, Corporate Constitutionalism: Antitakeover Charter Provisions as Precommitment, 152 U. PA. L. REV. 463, 484-88 (2003) (arguing that shareholders may benefit from granting boards control over tender offers because boards are better able to implement a selling strategy); Lynn A. Stout, The Shareholder as Ulysses: Some Empirical Evidence on Why Investors in Public 
employ value-reducing defenses that they would not utilize under a regime where they had substantially more control over which tender offers are allowed to go forward.

Under even the broadest shareholder choice proposal, managers would have available to them a wide range of unregulated and unregulable defenses. ${ }^{14}$ Existing shareholder choice proposals do not regulate all possible defenses. They generally limit the domain of shareholder choice to managerial actions that are targeted at, or occur during, hostile tender offers; they do not seek to regulate all ordinary business transactions that might deter tender offers, given shareholders' accepted inability to regulate such transactions. Thus, a substantial zone of business action would likely remain unregulated, even by the strongest shareholder choice regime.

Managers precluded by shareholder choice from pursuing currently popular defenses can utilize this unregulated zone to deter acquisitions, "embedding" defenses within a host of seemingly ordinary, and otherwise legitimate, pre-bid business transactions. ${ }^{15}$ Because these arrangements largely mimic transactions that are frequently value enhancing, they would almost certainly be beyond the purview of a shareholder choice regime, enabling managers to escape effective oversight of such defenses even when they reduce firm value.

A notable example of such an embedded defense is the inclusion of a "change of control" provision in an everyday business contract (such as a lease, joint venture, license, employment agreement or debt instrument) that imposes costs on the firm in the event of a change of control. ${ }^{16}$ Many companies use these provisions at present to enhance

Corporations Tolerate Board Governance, 152 U. PA. L. REv. 667, 686-87 (2003) (suggesting that giving ultimate control over the corporation's assets to the board may promote team production). See also Roberta Romano, The Political Economy of Takeover Statutes, 73 VA. L. REV. 111, 171-76 (1987) (finding that certain antitakeover provisions may benefit small shareholders).

${ }^{14}$ See infra Parts I.D \& II.C.2 (explaining why these defenses would be so difficult to regulate).

${ }^{15}$ In arguing that managers may adopt pre-bid embedded defenses, we do not claim that managers currently employ these measures regularly for defensive purposes. To the contrary, we contend that managers currently employ embedded measures primarily for legitimate reasons and entrench themselves using lower cost pure defenses, such as poison pills. Infra Part II. Thus, we view the potential substitution into embedded defenses as a cost of shareholder choice because managers have no need to resort to value-reducing embedded defenses under current law that enables them to deter hostile bids through more targeted means. If courts adopted proposals to give shareholders a greater voice over defensive measures, however, managers would have a strong incentive to adjust their own behavior toward such embedded defenses.

${ }^{16}$ See infra Part II (discussing the availability of pre-bid embedded defenses). 
firm value by reducing the costs of contracting with a third party, albeit at the cost of deterring some acquisitions. Under shareholder choice, however, managers could employ similar measures to deter acquisitions in situations where firm value is reduced. Such provisions are likely not regulable because shareholders and courts cannot reliably distinguish change of control provisions that are value enhancing when implemented from those that are value reducing when implemented. ${ }^{17}$

Accordingly, even when shareholders can directly regulate tender offers themselves, shareholder choice may reduce shareholders' welfare if it encourages managers to employ unregulable substitute defenses that reduce firm value, not only by deterring takeovers (friendly or hostile), but also by inefficiently altering the operating profile of the firm outside of the takeover context. ${ }^{18}$

There are a number of reasons to believe that embedded defenses (such as those described above) pose a sufficient threat to warrant caution before adopting any shareholder choice regime. First, as proponents of shareholder choice agree, courts and shareholders are

${ }^{17}$ See infra Part II.C.2 (discussing courts' inability to regulate such defenses).

${ }^{18}$ While others have noted the possibility of defense substitution, they have not examined either the breadth of available substitutes or whether managers can credibly threaten to adopt these substitutes even if doing so could decrease the probability of friendly deals. E.g., Jennifer Arlen, Designing Mechanisms to Govern Takeover Defenses: Private Contracting, Legal Intervention, and Unforeseen Contingencies, 69 U. CHI. L. REV. 917, 920, 928 (2002) (arguing that shareholder choice may not be optimal because shareholders may legitimately be reluctant to limit board power to impose existing defensive measures for fear that the board may respond with more destructive measures); see infra note 65 (discussing other articles addressing the possibility of defense substitution).

By contrast, the European debate over takeover law has been dominated by concern that extensive regulation of pure and post-bid defenses will simply induce managers to employ pre-bid defenses (otherwise known as preventive measures) as substitutes. See, e.g., John C. Coates IV, Ownership, Takeovers and EU Law: How Contestable Should EU Corporations Be? in COMPANY AND TAKEOVER LAW IN EUROPE (Eddy Wymeersch \& Guido Ferrarini eds., Oxford Univ. Press forthcoming 2003) (manuscript at $6-8,12$, on file with authors) (observing that the European Commission's proposed "break through" rule governing takeovers could have the adverse effect of inducing managers to substitute into alternative, value-reducing defenses); Paul Davies \& Klaus Hopt, Control Transactions, in THE ANATOMY OF CORPORATE LAW: A COMPARATIVE AND FUNCTIONAL APPROACH (forthcoming 2004) (on file with authors) (observing that managers can undermine existing European Union proposals to regulate post-bid defenses by implementing defenses before an offer materializes and noting that requiring pre-bid, shareholder approval of such defenses would be "too great an interference with the operation of centralized management"). Unlike this Article, these studies do not fully analyze the welfare implications of defense substitution resulting from shareholder choice. 
poorly positioned to regulate day-to-day managerial decisions made outside of the context of a tender offer, particularly those that potentially have legitimate business justifications. ${ }^{19}$ Thus, managers inevitably have available to them defenses that are unregulable.

Second, adoption of a shareholder choice regime would give managers a strong incentive to employ (indeed, even to invent) unregulable embedded defenses, even at the expense of firm value. ${ }^{20}$ Indeed, the strongest shareholder choice regimes may provide the greatest incentives for managers to adopt value-reducing substitute defenses. For example, should courts seek to regulate all defenses targeted at hostile deals, managers could instead employ pre-bid embedded "blanket" defenses, which circumvent hostile and friendly deals alike. Blanket defenses are particularly difficult to regulate because they are the most likely to serve nondefensive legitimate business purposes for some firms. ${ }^{21}$ These defenses also impose the greatest cost on the firm, since they deter all forms of acquisition.

Managers subject to such a strong shareholder choice regime might be willing to adopt blanket defenses, even when they would not do so under a managerial choice regime, because the shareholder choice rule itself reduces the costs that managers bear in deterring

${ }^{19}$ See infra Part I.D.1, II.C.2 (discussing the inability of courts and shareholders to regulate pre-bid embedded defenses); see, e.g., Beard v. Elster, 160 A.2d 731, 738-39 (Del. 1960) ("We are precluded from substituting our uninformed opinion for that of experienced business managers of a corporation who have no personal interest in the outcome, and whose sole interest is the furtherance of the corporate enterprise."); EASTERBROOK \& FISCHEL, supra note 10 , at 94 (identifying as rationales for the business judgment rule the notions that "judges lack competence in making business decisions," that a "fear of personal liability" will reduce managerial risk taking and deter talented people from serving as directors, and that "liability rules have only limited usefulness as a governance mechanism in the publicly-held corporation").

${ }^{20}$ Indeed, the history of mergers and acquisitions case law is largely defined by managers inventing and employing substitute defenses in response to efforts to regulate previously employed defenses. For example, the poison pill arose in response to efforts to regulate selective self-tenders. WILLIAM KLEIN, ET. AL, BUSINESS ASSOCIATIONS: CASES AND MATERIALS ON AGENCY, PARTNERSHIPS AND CORPORATIONS 784-85 (5th ed. 2003). As described by the court in Revlon, Inc. v. MacAndrews Eo Forbes Holdings, Inc., 506 A.2d 173 (Del. 1986), the managers of Revlon also employed an alternative substitute defense, in the form of debt-containing covenants designed to impede an acquisition, which were redeemable at the discretion of Revlon's board. Id. at 177 (describing these notes). Similarly, the managers of Time, Inc. responded to impediments to selective sales imposed by the Delaware court's opinion in Revlon, 506 A.2d at 184, through the defensive use of an acquisition by Time of Warner. Paramount Communications, Inc. v. Time, Inc., 571 A.2d 1140, 1149 (1990).

${ }^{21}$ See infra Part II.C.2 (discussing the difficulty courts would face in regulating blanket penalty change of control provisions). 
ostensibly friendly deals. ${ }^{22}$ Under a strong shareholder choice regime, bidders would concentrate on gaining shareholders' favor by maximizing share price at the expense of managers' private gains from the deal. Thus, managers would perceive most (if not all) acquisitions to be hostile, offering managers little in the way of private benefits. Consequently, the cost of deterring any truly friendly deals would be minimal, while the benefit of deterring hostile bids would be significant. Thus, rather than enhancing shareholder welfare, a strong shareholder choice regime might prove counterproductive by inducing managers to adopt measures that reduce the expected number of acquisitions (both friendly and hostile).

Third, shareholder choice proponents cannot rely on market forces (e.g., the market for managers) or the threat of a proxy contest to dissuade managers from employing such substitute defenses. The argument for shareholder choice itself is premised on the presumption that neither market forces nor the threat of proxy contests adequately deters managers from employing existing defenses to reduce firm value. There is no reason to expect that market forces and proxies would offer any greater impediment to managers' use of prebid embedded defenses. Indeed, such defenses would be even more difficult for markets and shareholder proxy contests to expose because managers adopting embedded measures have a more credible claim to be acting to maximize firm value.

Accordingly, even if shareholders had the incentive and the capacity to regulate tender offers, we conclude that shareholder choice may not increase shareholder welfare relative to the status quo ante. Although a strong shareholder choice regime may increase shareholder welfare for those takeovers that do occur, ${ }^{23}$ it would simultaneously give managers an incentive to retrench using substitute defenses that both (a) destroy value directly and (b) reduce the expected number of bids that ever reach shareholders. We are skeptical, therefore, that an immutable, one-size-fits-all rule is appropriate in such heterogeneous contexts. Rather, courts may wish to give increased deference to the choices shareholders themselves have made to grant

${ }^{22}$ Cf. Ronald J. Gilson, The Case Against Shark Repellent Amendments: Structural Limitations on the Enabling Concept, 34 STAN. L. REV. 775, 887-90 (1982) (arguing that the risk of substitution from post-bid defenses to pre-bid defenses is not particularly significant because managers will eschew blanket pre-bid defenses as these are too costly to managers).

${ }^{23}$ The effect of shareholder choice on shareholder welfare for those takeovers that do occur depends on the effect of shareholder choice on managers' compensation. Infra Parts II.D, IV.D and text accompanying notes 134-35. 
managers power over takeovers, whenever such choices appear to be clear. $^{24}$

In addition to the principal contribution described above, our analysis may shed light on a number of empirical quandaries within corporate scholarship. In particular, our analysis may provide an alternative explanation for shareholders' apparent acceptance of managerial choice. For example, recent studies have found that shareholders purchasing shares in initial public offerings (IPOs) do not appear to impose a penalty on firms that include antitakeover protections in their initial charters; indeed, firms regularly go public with such defenses. ${ }^{25}$ While some have interpreted these findings as evidence of either irrationality or inertia among capital market participants, ${ }^{26}$ our analysis suggests another interpretation: antitakeover protections do not induce a capital market discount because they reduce the risk of managers employing higher-cost substitute defenses. Additionally, our findings may help shed light on studies that find incentive compensation for executives to be negatively related to takeover impediments. $^{27}$

Before commencing with our argument, a few initial observations are warranted. First, although our analysis assumes that shareholder choice cannot extend to routine business decisions, our conclusions do not depend on the particular domain of shareholder choice. Our analysis holds for any shareholder choice rule, so long as there exists a zone of business actions in which managers can embed defensive actions that courts and shareholders cannot effectively regulate. ${ }^{28}$

${ }^{24}$ Thus, we are more cautious than others about whether courts can confidently invalidate antitakeover provisions to which shareholders consented (either at the IPO stage or through a shareholder vote). See, e.g., Gilson, supra note 22, at 822 (suggesting that courts invalidate certain pre-bid pure defenses notwithstanding shareholder approval). For a different argument favoring respect of shareholders' ex ante decisions to grant managers authority over takeovers, see Kahan \& Rock, supra note 13, at 484-89.

${ }_{25}$ See Robert Daines \& Michael Klausner, Do IPO Charters Maximize Firm Value? Antitakeover Protection in IPOs, 17 J.L. ECON. \& ORG. 83, 85-86 (2001) (finding that antitakeover provisions are common at the IPO stage and that about half the IPO firms studied adopted the strongest antitakeover protections).

${ }^{26}$ See, e.g., Michael Klausner, Institutional Shareholders, Private Equity, and Antitakeover Protection at the IPO Stage, 152 U. PA. L. REV. 20 (2003) (discussing explanations for why IPO firms include antitakeover protections).

${ }_{27}^{27}$ See infra Part VI.B (providing empirical evidence); see also Keith D. Harvey \& Ronald E. Shrieves, Executive Compensation Structure and Corporate Governance Choices, 24 J. FIN. RES. 495, 505 (2001) (finding that the relative absence of outside directors is negatively related to high-powered incentive compensation).

${ }^{28}$ Substitution presents a problem for many legal regimes. In the case of the mildest regimes, substitution may render the regime irrelevant if managers can easily 
Second, our argument is also robust to the possible responses that shareholders might employ to deal with value-reducing substitute defenses. In particular, our formal analysis incorporates the possibility that shareholders might attempt to deter managers from using substitute defenses by using incentive compensation schemes that tie managers' welfare more closely to the value of the firm. We show that such shareholder responses would not fully cure the problems presented by shareholder choice. Given the gains to managers of deterring hostile deals, shareholders may be unable, or unwilling, to make sufficient incentive payments to induce the efficient decisions. $^{29}$ Further, even when it is possible to offer managers appropriate incentive compensation to deter such defenses, we show that the amounts awarded may need to be so large that shareholders would be better off under a regime that simply granted managers the power to deter hostile bids. ${ }^{30}$

Finally, although our analysis focuses on a comparison of a strong shareholder choice regime with a strong managerial choice rule, we also examine more intermediate shareholder choice regimes. We find that intermediate regimes that adopt a categorical approach to defense regulation are similarly subject to problems of managerial substitution. By contrast, the problems of managerial substitution may be muted by a "fuzzy" regime that grants managers some latitude to favor friendly bidders over hostile ones, while raising the specter of court regulation without precisely delineating a zone in which courts will intervene. ${ }^{31}$

employ substitute defenses targeted at hostile deals. Efforts to expand the regulatory domain can lead to substitution into increasingly value-reducing measures. See, e.g., Stephen J. Choi \& Eric L. Talley, Playing Favorites with Shareholders, 75 S. CAL. L. REV. 271, 311-13 (2002) (noting a similar substitution effect in attempts to prohibit "favoritism" toward block shareholders).

${ }^{29}$ Indeed, most arguments for shareholder choice are predicated on the idea that executive incentive compensation does not adequately solve agency cost problems. See infra Part I.B (presenting arguments for shareholder choice). But see Marcel Kahan \& Edward B. Rock, How I Learned to Stop Worying and Love the Pill: Adaptive Responses to Takeover Law, 69 U. CHI. L. REV. 871, 896-97 (2002) (arguing that managerial choice is less costly than many assert because shareholders have employed adaptive mechanisms, such as executive incentive compensation, to mute the agency costs associated with managerial choice).

${ }^{30}$ See infra Part IV.D (showing that shareholders cannot erase the negative effects of shareholder choice through offering managers incentive contracts).

${ }^{31}$ Infra Part V.B (discussing the potential benefits of a "fuzzy" intermediate regime). This Article does not determine the optimal scope of a shareholder choice rule. Rather, its central contribution is to introduce an additional consideration that must be taken into account in the design of one. 
The remainder of this Article proceeds as follows. Part I examines the existing debate over shareholder choice and determines its limits and proper domain. In so doing, it identifies a previously unexamined zone of unregulable pre-bid embedded defenses. Part II establishes the existence of a wide variety of existing pre-bid embedded defenses that managers could employ to deter bids, free from effective court oversight. Part III examines whether managers would respond to shareholder choice by adopting value-reducing pre-bid embedded defenses they would not otherwise adopt. Part IV presents a more formal analysis of shareholder choice. Part V discusses the benefits of employing an intermediate regime. Finally, Part VI provides empirical support consistent with our findings.

\section{The Domain of Shareholder ChOICE}

This Part examines the debate over shareholder choice proposals. While the various incarnations of shareholder choice proposals are far from homogeneous, they share a few guiding principles that limit the domain of shareholder authority over takeover decisions. Thus, even the most expansive shareholder choice proposals do not seek to regulate all defensive measures that managers might employ. Yet the existence of unregulable defenses does more than delineate the outer bounds of shareholder choice; it also alters the relative merits of shareholder choice versus managerial control. We show that the gains from limiting managerial authority over regulable defenses depends on whether managers can respond by employing alternative, unregulable defenses that impose greater costs on the firm.

\section{A. Advantages of Managerial Control of Publicly Held Firms}

The separation of ownership and control is a defining characteristic of publicly held firms. Dispersed shareholders seek to maximize their gains from investing by contributing capital to publicly held firms managed by professional managers, who have considerable expertise but little personal stake in the firm. Shareholders of publicly held firms relinquish any right to exercise day-to-day control over the management of the firm. They give up this control in the expectation that firm value is maximized under the control of professional managers, notwithstanding the recognition that managers sometimes will be tempted to serve their own interests at the expense of shareholders. 
There are a number of reasons that professional managers are thought to have a comparative advantage over shareholders in governing public companies. In addition to being specifically trained for the task and better informed about the firm, managers can make informed decisions free from the costly collective action problems that plague decentralized governance. ${ }^{32}$ Even sophisticated shareholders generally are not sufficiently informed to manage the firms they own because they own a relatively modest fraction of any one company and thus have neither the incentives to acquire nor the capacity to analyze the information needed to make prudent, everyday business decisions. ${ }^{33}$ Moreover, professional management of everyday business is superior even if the board could readily provide shareholders with sufficient information because shareholders must exercise their judgment through voting-a process plagued by a host of coordination and collective action problems. ${ }^{34}$

This presumption favoring managerial control over the daily operations of publicly held firms-free from shareholder interferenceis expressed both in the considerable power over business operations granted to directors by Delaware General Corporation Law section $141(a)^{35}$ and in the accompanying restrictions placed by the business

${ }^{92}$ Indeed, the very reason publicly held corporations exist is to exploit the advantages of vesting control of the firm in professional managers who do not own the firm. See, e.g., Charles R.T. O'Kelley \& Robert B. Thompson, Corporations and Other BUSINESS ASSOCLATIONS 158 ( $3 \mathrm{~d}$ ed. 1999) (discussing the corporate form and its advantages).

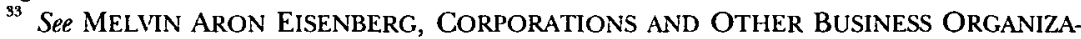
TIONS 159 (8th ed. 2000) ("[I]f a shareholder owns only a tiny amount of a corporation's stock, it is not cost-effective for her to spend a significant amount of time on the corporation's affairs. Such a shareholder, therefore, will be 'rationally apathetic."); see also O'KELLEY \& THOMPSON, supra note 32, at 158 ("A rational person in the shoes of a typical small stakes shareholder would not be inclined to bear the costs required to become fully informed about corporate affairs or to communicate with, and coordinate the actions of, other shareholders.").

${ }^{34}$ See EASTERBROOK \& FISCHEL, supra note 10, at 66 ("Indeed, the collective choice problems that attend voting in corporations with large numbers of contracting parties suggest that voting rarely serves any function except in extremis."); see also Ronald J. Gilson \& Alan Schwartz, Sales and Elections as Methods for Transferring Corporate Control, 2 THEORETICAL. INQUIRIES L. 783 (2001) (describing the problems with requiring a shareholder vote on takeover proposals). These are but a subset of arguments favoring managerial power. See, e.g., Margaret M. Blair \& Lynn A. Stout, A Team Production Theory of Corporate Law, 85 VA. L. REV. 247, 299-305 (1999) (justifying the business judgment rule as a mechanism for insulating boards of directors so that they might fairly arbitrate interconstituency disputes).

${ }_{35}$ See DEL. CODE ANN. tit. 8, \$141(a) (2001) ("The business and affairs of every corporation organized under this chapter shall be managed by or under the direction of a board of directors.") 
judgment rule on shareholders seeking to challenge board decisions. The rule constrains shareholders' authority to challenge management decisions by the board of directors and applies to both legal and equitable actions challenging a business decision by the board. The rule effectively insulates board actions from shareholder challenge unless the shareholder can show that the board was tainted by self-interest, was uninformed, or did not act in the good faith rational belief that its actions were in the best interests of the firm. ${ }^{36}$ Although the protection afforded by the business judgment rule obviously increases managers' ability to act in their own interests, the prevailing wisdom is that, in the course of ordinary business transactions, these costs of managerial authority are outweighed decidedly by the benefits of permitting professional managers to govern the firm, free from shareholder interference. ${ }^{37}$

\section{B. The Case for Shareholder Control over Tender Offers}

Proponents of maintaining managerial control over tender offers argue that the same considerations justifying the business judgment rule also apply to takeovers. Shareholders are not sufficiently well informed about the future value of the firm to evaluate a takeover bid, they argue, and do not have the requisite incentives to obtain the necessary information. In addition, even if shareholders were adequately informed, they would lack the capacity and business acumen to evaluate a bid properly. Consequently, managerial choice proponents contend, shareholders are far better off vesting authority over tender offers in the hands of expert managers (just as they do with other business decisions). ${ }^{38}$

${ }^{36}$ See, e.g., ROBERT C. CLARK, CORPORATE LAW 123-25, 136 (1986) (stating that the business judgment rule prevents shareholders from challenging managers' decisions that arguably are clear mistakes, unless the shareholders can show self-interest, lack of due care, or waste).

${ }^{37}$ See, e.g., EASTERBROOK \& FISCHEL, supra note 10, at 93-102 (arguing that shareholder litigation challenging board decision making is not a good method for deterring poor business decisions).

${ }^{38}$ See Martin Lipton, Pills, Polls, and Professors Redux, 69 U. CHI. L. REv. 1037, 1064 (2002) (arguing that it is important to "preserve the board's role as the best negotiator on behalf of the shareholders" because "mergers, acquisitions, takeovers and proxy fights and the legal rules applicable to them are complex"); Martin Lipton, Takeover Bids in the Target's Boardroom, 35 BUS. LAw. 101, 103-04 (1979) ("Takeover bids are not so different from other major business decisions as to warrant a unique sterilization of the directors in favor of direct action by the shareholders."). Some scholars discuss and criticize the "hidden value" argument for managerial authority. See Bernard Black \& Reinier Kraakman, Delaware's Takeover Law: The Uncertain Search for Hidden Value, 
By contrast, shareholder choice proponents generally agree that managers should exercise control over ordinary business decisions, ${ }^{39}$ but argue that managers should not control the fate of tender offers. ${ }^{40}$ Shareholders do not benefit from professional management posttender offers, shareholder choice proponents contend, because managers' judgment at that juncture is infected by self-interest. Because hostile acquisitions frequently presage managerial turnover, ${ }^{41}$

96 Nw. U. L. REv. 521, 521 (2002) (describing the hidden value justification for managerial choice, under which a firm's true economic value is visible to well-informed corporate directors, but not to the company's shareholders); Kahan \&c Rock, supra note 13, at 481-83 (discussing the view of "Hamiltonian" corporate scholars who assert that managerial decision making is better because managers have private information about future value that cannot optimally or effectively be shared with shareholders). Some scholars present other arguments that do not depend on managers' superior decision-making capacity. See sources cited supra note 13.

${ }^{39}$ See, e.g., WILLIAM T. ALLEN \& REINIER KRAAKMAN, COMMENTARIES AND CASES ON THE L.AW OF BUSINESS ORGANIZATION 252-53 (2003) (presenting arguments in favor of the business judgment rule); EASTERBROOK \& FisCHEL, supra note 10, at 93 (defending the business judgment rule).

Even the strongest proponents of shareholder choice typically stop short of advocating shareholder scrutiny over decisions about day-to-day management of the firm. For example, Lucian Bebchuk, who probably takes the most expansive view among prominent theorists of shareholder choice, nevertheless accepts the importance of professional managerial control over general business operations (as opposed to charter amendments and mergers). See, e.g., Bebchuk, supra note 9, at 996 (supporting managerial authority over investment decisions made in the ordinary course of business); LUCLAN ARYE BEbCHUK, THE CASE FOR EMPOWERING SHAREHOldERS 16 (Berkeley Olin Program in Law \& Econ., Univ. of Cal., Berkeley, Working Paper Series No. 86, 2003) ("Dispersed public shareholders would be better off remaining largely passive and having the company run by management. ... [T] he suggestion is to supplement centralized management with a power to intervene that can be expected to be used, at most, occasionally and to remain in the background most of the time."), available at http://repositories.cdlib.org/blewp/art86.

${ }^{10}$ See, e.g., Bebchuk, supra note 9, at 988-1028 (2002) (arguing for shareholder control over the fate of hostile offers); Lucian Arye Bebchuk, The Case for Facilitating Competing Tender Offers, 95 HARV. L. REV. 1028, 1034-38 (1982) (arguing for an auctioneering rule that allows managers to solicit bids but requires managers to submit bids to shareholders); Black \& Kraakman, supra note 38, at 559-63 (arguing that managers should be allowed to "just say no" to a bid subject to a shareholder veto at the next meeting, but should not be permitted to maintain a defense that allows it to "just say never"); Frank H. Easterbrook \& Daniel R. Fischel, The Proper Role of a Target's Management in Responding to a Tender Offer, 94 HARV. L. REV. 1161, 1194-1204 (1981) (arguing that managers should be completely passive in the face of a bid); Ronald J. Gilson, $A$ Structural Approach to Corporations: The Case Against Defensive Tactics in Tender Offers, 33 STAN. L. REV. 819, 848-65 (1981) (arguing for shareholder authority over tender offers).

41 See Kenneth J. Martin \& John J. McConnell, Corporate Performance, Corporate Takeovers, and Management Tumover, 46 J. FiN. 671, 677 (1991) ("The dramatic increase in the turnover rate of top managers following takeovers . . . indicates that takeovers are an important device for altering the top management of target firms ...."). 
managers have strong self-preservation motives to resist hostile deals altogether and favor those friendly acquisitions that provide either continued job security or an attractive managerial buyout (at shareholders' expense). ${ }^{42}$ Not only can these self-serving incentives reduce shareholder welfare at the point of a tender offer, they also can reduce firm value ex ante by muting the disciplinary effect of the market for corporate control. ${ }^{43}$

In addition, champions of shareholder choice contend, shareholders have a capacity to act in the context of a tender offer that they lack in the cool climate of ordinary business transactions. Tender offers are relatively rare, well-publicized occurrences in the life of a firm and tend to attract significant attention among the owners of a target firm. While shareholders ordinarily choose (rationally) to remain ignorant, the stakes involved in tender offers are sufficiently large to provide shareholders with the requisite incentive to become informed. Moreover, shareholders of tender offer targets may be more sophisticated than average because arbitrageurs and other sophisticated investors tend to buy likely targets. Accordingly, as managers cannot be trusted to act in the best interests of the shareholders, and shareholders can act on their own behalf post-tender offer, shareholder choice advocates argue that shareholders should be granted control over corporate decisions regarding tender offers. ${ }^{44}$

While shareholder choice proponents agree that boards should not have unfettered discretion at the point of a tender offer, they disagree about the exact circumstances under which shareholders should be able to override management's wishes and accept a proposed tender. These differences should not be surprising since, in the end,

${ }^{42}$ See, e.g., James F. Cotter \& Marc Zenner, How Managerial Wealth Affects the Tender Offer Process, 35 J. FIN. ECON. 63, 88-94 (1994) (offering empirical support for the claim that managerial resistance to tender offers appears to be driven by managers' selfinterest, rather than shareholders' interests); Ralph A. Walkling \& Michael S. Long, Agency Theory, Managerial Welfare, and Takeover Bid Resistance, 15 RAND J. ECON. 54, 67 (1984) (providing evidence of the connection between managerial success and takeover bid resistance).

${ }^{43}$ See Bebchuk, supra note 9, at 994 (arguing that board veto may lead to "managerial slack").

${ }^{44}$ See id. at 991-94 (arguing that shareholders are better able to regulate tender offers than managers who are infected with self-interest); Black \& Kraakman, supra note 38 , at 524-25 (critiquing the hidden value model and arguing that a shareholdercentered approach to takeover regulation is preferable); Easterbrook \& Fischel, supra note 40, at 1199-1201 (proposing that managers should play a more passive role regarding tender offers); Gilson, supra note 40, at 845-48 (proposing that mangers should not be able to prevent hostile offers). 
shareholder choice constitutes an exception to the general rule favoring professional management. ${ }^{45}$ Proponents of shareholder choice express varying views about those circumstances where shareholders have the incentives to obtain, and the capability to act upon, the information necessary to override managerial resistance to a hostile tender offer because different takeover defenses place heterogeneous burdens on shareholders' decision-making capacity. Thus, the variation among shareholder choice proposals generally reflects disagreements about which defensive measures shareholders practically are capable of evaluating and invalidating. Understanding this heterogeneity has important implications not just for the domain of shareholder choice, however, but also for the potential validity of all shareholder choice proposals.

\section{Taxonomy of Defensive Measures}

Shareholder choice proponents generally agree that the outer limits of shareholder choice depends upon shareholders' ability to obtain and analyze the information necessary to exercise an informed choice about the relative merits of a tender offer, as compared to any actions managers have taken to deter the hostile offer. ${ }^{46}$ Thus, even the most ardent choice proponents agree that shareholder choice should be limited to those situations where shareholders have sufficient incentives to obtain, and capacity to analyze and act on, the information necessary to evaluate the merits of the defensive measure in question.

To understand the practical constraints on shareholders' ability to evaluate managers' defensive actions, it is useful to distinguish takeover defenses based on two criteria: (1) whether the defense is adopted

${ }^{45}$ See Bebchuk, supra note 9, at 995-96 (asserting that shareholders should be granted authority over takeovers even though it would not be viable to grant them authority over ordinary business decisions).

${ }^{4}$ As shareholder choice proponents recognize, ensuring that shareholders are sufficiently informed to evaluate whether to override a managerial defense is a necessary, but not sufficient, condition for vesting them with control. In addition, shareholders must be able to act collectively in their best interests. For a discussion of whether voting or a tender offer best facilitates shareholder decision making, compare Gilson \& Schwartz, supra note 34 , at $790-92$, which argues that a straight tender offer is preferable to requiring a shareholder vote on takeover proposals, with LUCIAN ARYE. BEBCHUK \& OLIVER HART, TAKEOVER BIDS vS. PROXY FIGHTS IN CONTESTS FOR CORPORATE CONTROL 5 (John M. Olin Ctr. for Law, Econ., \& Bus., Harv. Law Sch., Discussion Paper No. 336, 2001), available at http://www.law.harvard.edu/programs/olin_ center, which argues that shareholder voting on acquisitions is preferable to decision making through the tender offer process. 
in the shadow of a hostile bid or is adopted in the ordinary course of business (well before a takeover bid seems likely) and (2) whether the defense is a pure defense solely tailored to deter hostile offers or is embedded in an ordinary business transaction that conceivably could be in the firm's best interests notwithstanding its effect on potential tender offers. These two distinctions, in turn, motivate a simple taxonomy of defenses through a two-by-two matrix, pictured in Table 1 below. In the matrix, the timing dimension of the defense is represented on the horizontal axis while the tailoring dimension is on the vertical axis:

Table 1. A Simple Taxonomy of Defenses

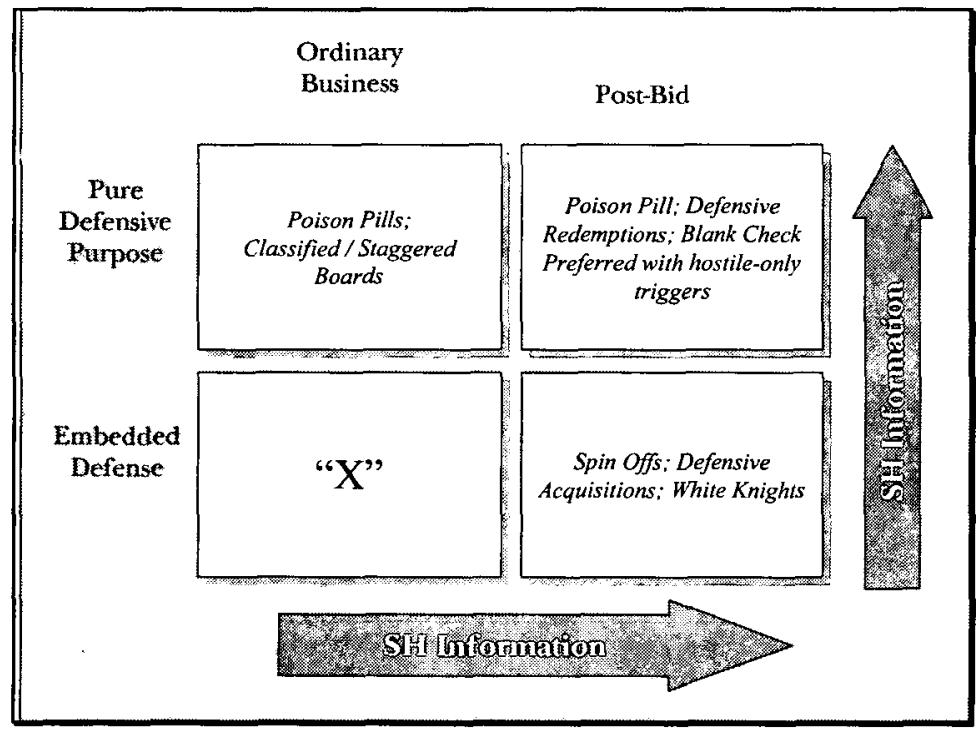

As the matrix reflects, the intuitive claim for shareholder capacity to make informed business decisions is stronger in the case of post-bid defenses than for pre-bid defenses and is stronger for pure defenses than embedded defenses. Accordingly, the focus of shareholder choice proposals has been on granting shareholders authority over defenses falling in the right column and the top row of the matrix (i.e., the $\mathrm{NW}, \mathrm{NE}$, and SE quadrants). We consider each dimension in turn.

\section{Pre- Versus Post-Bid Defenses}

Consider first the distinction between defenses implemented before a bid is imminent (i.e., in the ordinary course of business) and 
those implemented post-bid (or once a takeover is imminent). Shareholders are generally presumed to be better able to determine whether to override a post-bid defensive measure than a pre-bid measure because shareholders are better informed and have a greater incentive to act in the heat and light generated by a tender offer. As previously discussed, a takeover bid rarely occurs in the life of a firm and has enormous potential consequences for shareholders when it does. These high stakes provide shareholders with significant incentives to become informed. Moreover, the costs to shareholders of obtaining information are likely to be lower post-bid than in the course of ordinary business transactions since a tender offer not only signals one bidder's outside evaluation of firm value, but it also results in intense scrutiny by other potential buyers, investors, research analysts, and the press. ${ }^{47}$

The post-bid environment also diminishes the collective action problems that normally attend shareholder governance. Shareholders are better able to act post-bid because target firms often end up with a proportionately greater number of informed investors, such as arbitrageurs, investment banks, and institutional investors. Thus, even if shareholders are generally ill-positioned to make business decisions in the ordinary course of business, they are better equipped to do so in the heated crucible of the post-bid environment. Accordingly, many shareholder choice proponents argue that, once a bid has been made (or becomes imminent), managers should not be able to adopt defenses that would defeat a hostile offer. ${ }^{48}$

By contrast, shareholders frequently have relatively less ability to assess the merits of potential defensive measures implemented pre-bid, outside the glare of a contest for control. In the cool climate of ordinary business transactions, shareholder decision-making capacity is at its least effective. Indeed, shareholders' presumed decision-making deficit in this context justifies the separation of

${ }^{47}$ See, e.g., Bebchuk, supra note 9, at 999-1004 (arguing that, when shareholders' "money is on the line" following a takeover bid offer, they have a great incentive to make an informed, rather than purely deferential, choice).

${ }^{48}$ E.g., id. at 1027-28; Gilson, supra note 40, at 878-79 (arguing that, once a bid is imminent, managers should not be permitted to employ defenses that interfere with shareholders' opportunities to tender their shares); see also Easterbrook \& Fischel, supra note 40, at 1194-1204 (arguing for managerial passivity in the face of a hostile offer).

As we will discuss, similar arguments apply to pre-bid pure defenses whose ultimate effect is to grant managers post-bid control over the tender offer process (e.g., a redeemable poison pill). Infra note 52 and text accompanying notes $50-53$. 
ownership and control that defines the governance of publicly held firms. ${ }^{49}$

\section{Pure Versus Embedded Defenses}

A second important distinction pertains to timing, rather than tailoring: whether the action is a "pure defense" adopted for the sole purpose of deterring hostile bids (with little other direct effect on the operating profile of the firm) or an "embedded defense" that could serve legitimate business purposes. Because pure defenses have (by definition) no effects other than to deter managerially disfavored acquisitions, they are likely to be easier for shareholders to evaluate than are embedded defenses, whose purposes may often be mixed and therefore difficult to distill.

The distinction between pure and embedded defenses becomes particularly important if, post-bid, shareholders have the potential capacity to assess whether to proceed with a tender offer or allow present management to remain in control. Pure defenses are measures that give managers a veto over tender offers, with no other effect on the operations of the firm. A classic example of such a measure is the poison pill, which has no effect on firm value except to the extent that it discourages hostile acquisitions. ${ }^{50}$ These defenses confer little benefit on the firm if shareholders are able to evaluate tender offers that eventually emerge. Accordingly, shareholder choice proponents generally favor allowing shareholders to exercise control over pure defenses (e.g., nullifying a poison pill), in order to ensure that shareholders, not managers, control which takeovers succeed. ${ }^{51}$

Significantly, under many such proposals, shareholders need not act to negate a pure defense at its inception, but can wait to act until a tender offer has materialized, analyzing the firm's existing prospects

${ }^{49}$ See Bebchuk, supra note 9, at 996 (asserting that shareholder authority over ordinary business decisions "is not a viable option").

${ }^{30}$ Poison pills can be promulgated either in the ordinary course of business or after a takeover bid has become imminent. They are used to discourage acquisitions by causing the firm to disgorge value to non-bidder holders of the firm's securities when a hostile bidder crosses a pre-specified threshold level of ownership. Poison pills are designed to discourage a bidder from ever obtaining the triggering ownership amount, and therefore, are rarely triggered. Cf. William J. Carney \& Leonard A. Silverstein, The Illusory Protections of the Poison Pill, 79 NOTRE DAME L. REV. (forthcoming) (questioning whether acquirers should be so wary of triggering pills).

${ }^{51}$ See, e.g., Bebchuk, supra note 9 , at 1027-28 (arguing that boards should not be permitted to maintain a pure defense, such as a poison pill, if shareholders either vote for the acquisition or vote against the board in a proxy context). 
in the relatively information-rich context subsequent to a bid. 5 ? Moreover, to evaluate whether to retain a pure defense or accept a tender offer, shareholders need only compare the merits of the acquirer's bid against their best estimate of the value of the status quo (a value for which they possess relatively good information). Accordingly, if shareholders can evaluate tender offers post-bid, then courts can confidently vest them with authority to override pure defenses (whether adopted pre-bid or post-bid) without fear of reducing the benefits shareholders obtain from professional management. Under this view, defenses in the northern half of the matrix might be well suited to shareholder regulation. .s $^{3}$

By contrast, regulation of embedded defenses presents a greater problem. Embedded defenses are actions that managers purport to take for legitimate (nondefensive) business reasons that also may deter tender offers (either hostile bids or all bids generally). ${ }^{54}$ These defenses include actions requiring shareholder approval, such as the decision to classify stock or merge with a firm other than the hostile bidder. Yet they also include actions managers can take unilaterally, such as spinning off a subsidiary or adopting change of control provisions in important contracts.

Embedded defenses present particular problems for shareholder choice proponents because they entail the type of fundamental business decisions that are usually best left to professional managers.

${ }^{52}$ In the case of pre-bid pure defenses, shareholders can wait to evaluate the defense until a tender offer has materialized, since, by definition, the pure defense neither imposes legitimate reliance interests in third parties, nor does it impose irreversible sunk costs on the company.

is See, e.g., Bebchuk, supra note 9, at 1027-28 (arguing that boards should not be able to maintain control over tender offers once shareholders vote for the acquisition or against the board in a proxy context); Black \& Kraakman, supra note 38, at 561-62 (arguing that boards should not be able to maintain pure defenses, like the pill, if shareholders support a hostile bid). But see Kahan \& Rock, supra note 13, at 484-90 (arguing that managerial authority over tender offers may be welfare-enhancing if it enables managers-better able than shareholders-to implement a selling strategy).

Perhaps the only circumstance under which managers should be allowed to maintain a pure defense, choice advocates argue, is when it is used as bargaining leverage to negotiate a better deal for shareholders. Once the raider has made its tender offer, proponents contend, management should be required to submit the decision to the shareholders and should be forced to remove all pure defenses if shareholders vote to approve the deal. See, e.g., Bebchuk, supra note 9, at 975, 1027-29 (arguing that boards should not be able to maintain pure defenses that would prevent shareholders from accepting unsolicited tender offers).

${ }^{54}$ This includes the defenses that may deter both hostile and friendly deals alike. See infra Part II.B (discussing how management may target hostile, rather than friendly, deals through its use $\cdot$ of targeted embedded defenses). 
Embedded defenses usually can be justified as serving legitimate business purposes, notwithstanding their negative impact on takeovers. Yet whether an embedded defense in fact enhances or reduces value for a particular firm depends on the relative magnitudes of these effects in each case. For some firms, an embedded defense may enhance firm value, notwithstanding its negative impact on tender offers, as the embedding action may promise significant investment opportunities or gains from trade. For other firms, the same transaction may do little beyond deterring takeovers, thereby reducing firm value. It is therefore difficult for shareholders and courts to distinguish beneficial and wasteful embedded measures on a priori grounds.

While accepting that shareholders are less able to evaluate embedded defenses than pure defenses, some shareholder choice proponents hold fast to the claim that shareholders should have authority to regulate at least one class of embedded defenses-those adopted after a hostile bid becomes imminent. ${ }^{5.5}$ Proponents of this approach recognize that granting shareholders authority to override embedded defenses at the post-bid stage would tax shareholder decision-making capacity heavily, requiring shareholders to compare (a) the value represented by the tender offer bid, with (b) the value represented by remaining with existing management, but with a firm that is altered by the contemplated embedded defense. ${ }^{56}$ While this is a heavy burden, these shareholder choice proponents assert that the post-bid stage so alters shareholders' decision making - both in terms of the quality of information and the identity of the shareholders ${ }^{57}$ - that shareholders can exercise informed choice and thus should be vested with ultimate authority to decide the fate of post-bid embedded defenses. ${ }^{58}$

${ }^{55}$ E.g., Bebchuk, supra note 9, at 1028-29 ("Once mechanisms to ensure undistorted shareholder choice are in place, boards should not be permitted to block offers beyond the point necessary for putting together alternatives for shareholder consideration.").

${ }^{56}$ The greater the impact of the embedded defense, the more difficult it will be for shareholders to compare the merits of the altered firm with the value offered in the bid. Shareholders encountering defenses that do little to alter the existing firm may be similarly situated to those facing a pure defense. For a firm considering a substantial change, like a merger with a similarly sized or larger firm, it is considerably more difficult for shareholders to evaluate the future of the altered target.

${ }^{57}$ See supra Part I.B (explaining how incentives for shareholders to evaluate information increase in the post-bid environment).

${ }^{58}$ This can be made operational through several means. For example, boards contemplating a business decision that would defeat the hostile bid could submit the question to shareholders of whether to accept the bid or to proceed with management's new business plan. In doing so, the board can provide shareholders with information and arguments supporting their preferred course of action. See Bebchuk, 
Nevertheless, and significantly, there does not appear to be any serious shareholder choice proposal that would give shareholders authority over embedded defenses implemented at the pre-bid stage. This reticence likely reflects the presumed difficulty that shareholders (and courts) would have in assessing the relative merits of what otherwise appears to be an ordinary business decision. ${ }^{59}$

\section{The Importance of the Unexamined Fourth Quadrant}

As described above, even the strongest shareholder choice proposals are limited to extending shareholder control to all pure defenses and all post-bid defenses: that is, the northern and eastern three quadrants of Table 1. There exists, however, a fourth quadrant of the Table that these proposals leave untouched: embedded defenses adopted at the pre-bid stage. Such defenses are transactions that the board undertakes in the ordinary course of business, ostensibly for legitimate (nondefensive) business purposes, but which also may have a defensive effect. These measures include those that a firm might take even if there was no imminent threat of a hostile acquisition, but that nevertheless deter takeovers. For example, a firm may choose to merge with another firm or employ a change of control provision in a contract with a third party primarily to enhance value yet these measures also may be employed to deter tender offers at the expense of firm value.

The existence of these defenses has potentially significant implications for shareholder choice, detailed below.

\section{Unregulable Defenses}

No leading proponent of shareholder choice has sought to regulate managers' authority over all pre-bid embedded defenses, either by requiring contemporaneous shareholder approval of all transactions affecting future takeovers or permitting shareholders to invalidate any such measures ex post, once a bid has emerged. ${ }^{60}$

supra note 9, at 1000-01 ("[F]ollowing the making of an offer, directors can and often do provide shareholders with new information... about the target's independent value and how it compares with the price."); Black \& Kraakman, supra note 38 , at 563 (arguing that boards seeking to accept one transaction and reject a second transaction offering higher visible value should have to obtain shareholder ratification).

${ }^{59}$ E.g., Bebchuk, supra note 9, at 996 (asserting that shareholders cannot regulate pre-bid investment decisions).

${ }^{60}$ Both current U.S. proposals and European law fall short of regulating all, or even most, pre-bid embedded defenses. For example, although the United Kingdom's 
As a practical matter, pre-bid embedded defenses are an elusive target for shareholder oversight because they are adopted in the cool, information-poor context of everyday business, often well before a tender offer might ever emerge. Complicating matters is the fact that these defenses come clothed as otherwise legitimate business transactions that potentially confer significant benefits on the firm.

City Code tightly restricts managers' ability to implement "defensive measures" once a takeover bid is imminent, it does not regulate managers' adoption of "protective measures" implemented well in advance of a takeover. Eddy Wymeersch, Problems of the Regulation of Takeover Bids in Western Europe: A Comparative Survey, in EUROPEAN TAKEOVERS: LaW AND PRACTICE 95, 122 (Klaus J. Hopt \& Eddy Wymeersch eds., 1992). In response, many European, especially Continental, companies have adopted strong protective devices that significantly impede takeovers. Id.; see also infra note 72 (discussing European companies' use of golden share arrangements to deter foreign hostile bidders).

Moreover, Europe's experience with the Thirteenth Directive (the European Commission's proposal for harmonizing corporate takeover law throughout the Union), Commission Proposal for a Directive of the European Parliament and of the Council on Takeover Bids, art. 11, 2003 O.J. (C 45) 6, 7, available at http:// europa.eu.int/eur-lex/pri/en/oj/dat/2003/ce045/ce04520030225en00010017.pdf, reveals some of the difficulties associated with pre-bid defenses. Following the rejection of the Thirteenth Directive by the Parliament of the European Union in July 2001, the European Commission established a High Level Group of Company Law Experts to consider a rule to govern takeover defenses. See Christian Kirchner \& Richard W. Painter, Takeover Defenses Under Delaware Law, the Proposed Thirteenth EU Directive and the New German Takeover Law: Comparison and Recommendations for Reform, 50 AM. J. COMP. L. 451, 460-61, 468 n.60 (2002) (describing controversy among EU members concerning the directive). The High Level Group of Company Law Experts explicitly addressed the problem of managers' use of substitute defenses should the European Union regulate post-bid defenses. Id. at 468-69. The group concluded that shareholder authorization should be required for any defenses implemented during an acquisition. The group rejected proposals to require shareholder authorization of defenses adopted within eighteen months of a bid, however, on the grounds that pre-bid shareholders are not sufficiendy informed to make such determinations. Id. at 469 .

To regulate certain pre-bid defenses-specifically certain shareholder voting structures, such as "golden shares"-the group proposed a "break through" rule, which would "nullify and void preferential positions of certain shareholders" for purposes of a shareholder vote on the takeover bid. Id. at 468-69. This break through rule has numerous problems. See Coates, supra note 18 (analyzing this rule and concluding that it is not clearly better than the current legal regime). First, the break through rule would reduce firm value for those firms where the regulated capital structures are value enhancing. Second, it would not eliminate the problem of pre-bid defenses because it leaves untouched various other pre-bid defenses that are functionally equivalent, including the main group of pre-bid defenses identified in this Article. See id. at 7-8 (discussing boards' ability to use alternative defenses, such as stock pyramids and cross-ownership, to replicate the effects of dual class stock); Kirchner \& Painter, supra, at 470-71 (noting that the High Level Group identified share transfer restrictions, contract provisions, and "pyramid structures" as pre-bid defenses that are practically the same as those covered by the rule, but still available). 
Thus, it would not be prudent for shareholders to interfere with managers' authority over pre-bid embedded defenses because neither shareholders nor courts have the capacity to regulate these measures. First, it is neither practical nor prudent to adopt a categorical prohibition on all pre-bid actions that might deter takeovers. It is not always possible to determine ex ante whether any given transaction significantly impedes acquisitions, particularly when its deterrent effect depends on other actions the board might take. Moreover, even when a transaction clearly deters takeovers, prohibiting it may frequently deprive firms of significant benefits that could (depending on the case) far outweigh any costs. ${ }^{61}$

Nor is it either possible or desirable to regulate pre-bid embedded defenses ex ante, by requiring contemporaneous shareholder approval of any pre-bid measure that could deter takeovers. The range of pre-bid embedded defenses is so large that requiring shareholder authorization of all such actions would dramatically increase the costs of a great variety of corporate transactions. Moreover, shareholder voting on such transactions is unlikely to confer significant benefits because shareholders are not capable of overseeing ordinary business transactions, with or without defensive effects. Indeed, the foundational premise of the publicly held firm is that shareholders do not have sufficient incentives to obtain, or capacity to analyze and motivation to act upon, the information necessary to make good decisions regarding ordinary business transactions. ${ }^{62}$ The fact that an ordinary business transaction might deter future (purely hypothetical) tender offers does not substantially alter this scenario. Such ordinary transactions are unlikely to generate attention from analysts, the press, and institutional investors associated with tender offers. Thus, requiring shareholders to approve any ordinary business transaction that burdens a future tender offer would force shareholders to exercise authority in the very circumstance-and over the very transactions-in which they are least capable of acting effectively.

${ }^{61}$ See infra Part II (discussing pre-bid embedded defenses).

${ }^{62}$ E.g., Bebchuk, supra note 9, at 996 (positing that shareholders are not sufficiently well informed to make investment decisions in the ordinary course of business). Indeed, for this reason, a number of shareholder choice advocates generally accept the idea that courts should regulate shark repellents (such as fair price amendments), notwithstanding that they require shareholder approval. See, e.g., Gilson, supra note 22, at 822-27 (claiming that shareholders approve shark repellent amendments contrary to their own self-interest because unsophisticated shareholders are rationally uninformed about these measures, and sophisticated shareholders find it too costly to intervene to inform the unsophisticated shareholders). 
Accordingly, granting shareholders such authority would undermine their ability to retain the benefits of professional managerial control over ordinary business transactions without conferring the benefits of informed shareholder oversight of managers. ${ }^{63}$

Finally, it is also neither desirable nor feasible to regulate such defenses by allowing shareholders or courts (or both) to decide their fate ex post, once a tender offer has emerged. Many firms benefit not only from embedding a pre-bid defense in a larger transaction, but also from being able to commit to that term. For example, embedding change of control provisions in a third-party contract may reduce the firm's cost of contracting by giving the third party some security about the future trajectory of the firm. This reduced contracting cost is partially passed on to shareholders, but only to the extent that the firm can commit to abide by the term once a tender offer emerges. Firms would likely not obtain such benefits if third parties expect shareholders (or courts) to invalidate such measures ex post in order to proceed with a tender offer. ${ }^{64}$

\section{The Problem of Substitution}

The existing debate over shareholder choice generally has proceeded on the premise that the challenge of regulating pre-bid embedded defenses (i.e., the southwest quadrant of Figure 1) only affects the domain of shareholder choice, and not the merits of shareholder

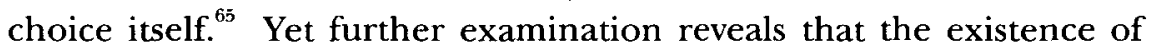

${ }^{63}$ See Arlen, supra note 18 , at 920 (observing that corporate constituents cannot write contracts that simply prohibit all pre-bid antitakeover devices because it is often hard to distinguish an antitakeover device from a legitimate business action and furthermore, shareholders cannot anticipate in advance all the possible measures that managers might employ).

${ }^{64}$ See supra note 60 (discussing problems with the European Union's proposed break through rule).

${ }^{65}$ A few scholars examining U.S. law have observed that shareholder choice might induce managers to employ substitute defenses, but they generally have not explored the degree to which this possibility indeed undermines the case for shareholder choice. See Arlen, supra note 18, at 928 (arguing that regulating existing defensive measures may reduce shareholder welfare if it induces managers to employ alternative defenses that are more destructive of firm value); Kahan \& Rock, supra note 29, at 903 ("[A]s long as boards retain ... the power to manage the company, a unilateral, boardopposed governance measure is likely to induce a strategic response by the board."); cf. Atreya Chakraborty \& Richard Arnott, Takeover Defenses and Dilution: A Welfare Analysis, 36 J. Fin. \& QUANTITATIVE ANALYSIS 311, 311-12, 329 (2001) (proposing that hostile offers may provide less discipline on managers than theorists have suggested because the primary gain from hostile tender offers may arise from undoing the effects of value-reducing defenses that managers would not have adopted if not threatened by 
these types of defenses may be far more significant than most commentators have heretofore appreciated. The very existence of unregulable, and potentially wasteful, pre-bid embedded defenses potentially undermines the normative case for shareholder choice because regulating pure and post-bid defenses may reduce shareholder welfare if managers respond by substituting into pre-bid embedded defenses that impose greater costs on the firm.

Managerial substitution into fourth quadrant defenses is a potentially serious concern because shareholder choice proposals neither remove managers' incentives to entrench themselves nor ensure managerial passivity. Rather, they merely regulate certain forms of managerial entrenchment.

Under all shareholder choice regimes, managers would retain other means of entrenchment and could be expected to employ these unregulated defenses to protect their tenure. Accordingly, rather than surrendering their authority, managers subject to shareholder choice can simply relocate their entrenchment activities further upstream, embedding defenses in unregulable pre-bid decisions that arguably have nonentrenchment justifications. Moreover, managers may be able to implement such measures even when they are value

potential hostile takeovers in the first place); supra note 18 (citing authorities that discuss European proposals to regulate defensive measures).

Nevertheless, a number of scholars have discussed the implications of substitute defenses for proposals to regulate particular defenses, even if they have not examined the broader implications of substitute defenses. See, e.g., Lucian Arye Bebchuk et al., Stock Pyramids, Cross Ownership, and Dual Class Equity: The Mechanism and Agency Costs of Separating Control from Cash-Flow Rights, in CONCENTRATED CORPORATE OWNERSHIP 295 (Randall K. Morck ed., 2002) (showing how managers can use pyramids and crossholding structures to achieve the same control and cash-flow rights available through dual class structures); Gilson, supra note 22, at 818-22, 887-90 (recognizing that regulation of post-bid shark repellents may induce substitution into unregulated, prebid shark repellents, but concluding that managers would not employ the least targeted (and most unregulable) of these pre-bid measures); Ronald J. Gilson, Evaluating Dual Class Common Stock: The Relevance of Substitutes, 73 VA. L. REV. 807, 843-44 (1987) (examining both dual class common stock and substitutes that accomplish the same result); see also Marcel Kahan \& Michael Klausner, Antitakeover Provisions in Bonds: Bondholder Protection or Management Entrenchment?, 40 UCLA L. REv. 931, 954 (discussing managers' defensive use of debt covenants with change of control puts triggered only by a hostile offer); Edward B. Rock, Controlling the Dark Side of Relational Investing, 15 CARDOZO L. REv. 987, 1006-07 (1994) (discussing managers' ability to use the issuance of sweetheart preferred stock, preferred stock issued to a corporate insider, to defend against a hostile offer). 
reducing if the value-reducing defenses mimic measures that enhance value for some firms. ${ }^{66}$

Furthermore, shareholders cannot rely on nonlegal restraints on managers' behavior-such as the threat of a proxy contest or the market for managerial services-to deter managers from adopting such value-reducing measures. The case for shareholder choice itself is predicated on the view that neither the proxy process nor the market for managers adequately deters managers from employing antitakeover defenses at the expense of shareholders. There is no reason to expect these measures to deter pre-bid embedded measures if they do not deter pre-bid pure defenses.

Indeed, the proxy process and market for managers are likely to be even less effective in the case of pre-bid embedded defenses than in the case of pure defenses because, in the latter case, shareholders often are unable to determine whether the measure is value enhancing or value reducing at the time it is adopted. To the extent that shareholders cannot reliably determine whether to commend or sanction managers for adopting a pre-bid embedded measure, alternative disciplinary measures that depend on shareholders are unlikely to be effective. ${ }^{67}$

${ }^{66}$ Some readers may identify our argument with the intuitions generated within the multitasking literature, which examines the problem of providing incentives to agents when only certain aspects of their actions are observable. In such circumstances, it may be optimal to "soften" incentives as to observable actions so that agents spend more time on unobservable actions. Bengt Holmstrom \& Paul Milgrom, Multtask Principal-Agent Analyses: Incentive Contracts, Asset Conership, and Job Design, 7 J.L., ECON. \& ORG. 24 (1991). Notwithstanding this similarity, our analysis is in many ways distinct from the multitasking literature. First, multitasking models generally examine situations in which an agent must undertake multiple activities-e.g., increasing speed and enhancing quality-each of which independently affect the principal's profits, but only some of which are observable. To be sure, in our framework shareholders would like to deter numerous types of managerial action that deter acquisitions, but cannot deter some without exacerbating others. Significantly, however, the various actions that managers may take in our framework are not independent, but may be mutually exclusive means for affecting the likelihood of a tender offer. Moreover, the reason shareholders cannot deter each of them individually is unrelated to observability of the actions; indeed, shareholders usually can observe pre-bid embedded defenses. Rather, shareholders cannot regulate such measures because they cannot determine ex ante whether certain defenses enhance or reduce firm value. Finally, the classic multitasking approach focuses only on optimal contracting practices, holding constant the underlying legal regime. By contrast, our analysis examines the optimal structure of the legal regime itself, accounting both for incentives to employ substitute defenses and likely contractual responses in the shadow of this regime.

${ }^{67}$ Moreover, even if shareholders can determine that a pre-bid measure is value reducing, it may not be in their interests to remove managers through a proxy contest. Shareholder incentives to change management depend on producing a sufficient 
Accordingly, the desirability of a shareholder choice regime turns critically on the threat that managers may substitute into unregulable defenses that may place a greater net burden on firm value than those defenses that a shareholder choice regime would place under scrutiny. It is to this inquiry that we now turn.

\section{AVAILABILITY OF PRE-BID EMBEDDED DEFENSES}

In this Part, we move from logical taxonomy to practical application, examining the extent to which managers may realistically be able to embrace pre-bid embedded defenses as a response to a shareholder choice regime. An important starting point for this inquiry is to examine existing corporate practices themselves, assessing the extent to which such practices already provide an institutional template for unregulable defenses. We find that there is a cornucopia of alternative pre-bid embedded measures that managers could employ to retain control over or deter acquisitions should they be prevented from employing more targeted, post-bid measures. ${ }^{68}$

Of particular importance, we identify a variety of practices that, under current law, managers generally employ solely for their valueenhancing, nondefensive effects, but which could just as easily serve to embed a defense at the expense of firm value. Existing pre-bid "blanket" defenses (which deter hostile and friendly deals alike) are particularly likely to be used for legitimate business purposes where currently employed because, under current law, managers have no need

improvement in firm value to outweigh the costs of a proxy contest. Although ex ante shareholders might benefit from threatening to remove a board that adopts defenses, after the fact it may not be in their interest to do so because many pre-bid embedded defenses cannot be removed by the board post-bid. Thus, once a nonremovable defense is adopted, shareholders may have little expectation of an acquisition and may obtain the greatest expected share value under current management. Accordingly, when shareholders cannot eliminate the effect of defenses by changing the current management team, they may have little reason to change current management. $C f$. Jennifer H. Arlen \& Reinier Kraakman, Controlling Corporate Misconduct: An Analysis of Corporate Liability Regimes, 72 N.Y.U. L. REV. 687, 712-17 (1997) (discussing how the commitment problem renders ineffective principals' ex ante threats to sanction wrongful agents because agents know that ex post, should a wrong occur, principals may obtain little benefit from actually carrying out the threat).

${ }^{68}$ Board efforts to retain control need not be limited to rearranging internal corporate affairs. Managers can be expected to respond to an effort by the Delaware Court to implement shareholder choice by lobbying the legislature for stronger antitakeover protections. 
to deter friendly deals when they can "just say no" to hostile raiders alone. ${ }^{69}$

While, at present, managers generally employ such measures when they benefit the firm, managers subject to a shareholder choice regime would have an incentive to resort to such defenses-even at the expense of shareholder welfare-if precluded from employing more targeted defenses by shareholder choice. Courts could not easily regulate such substitute defenses, however, if managers can implement defenses that mimic legitimate, value-enhancing business transactions. Thus, the evidence we present of legitimate, value-enhancing transactions that could be employed for defensive purposes, strengthens the claim for the "unregulability" of various pre-bid embedded defenses.

\section{A. The Degree of Targeting}

To evaluate the risk of managerial substitution into pre-bid embedded defenses-and the difficulty courts would face in regulating them-it is useful to distinguish between targeted pre-bid measures designed to enable boards to retain control over which bid succeeds (without imposing any costs on friendly deals), and "blanket" defenses, embedded deep within other business decisions, that deter all acquisitions, friendly and hostile alike.

Managers subject to a shareholder choice regime would find targeted defenses to be the most attractive because they deter hostile offers while maintaining management's ability to enter into friendly deals. Of course, these defenses also are the least likely to serve bona fide nondefensive interests and, thus, are the most vulnerable to court

${ }^{69}$ Managers who are not selling control of the firm can employ pure defenses or post-bid defenses to "just say no" to all acquirers. See supra text accompanying notes 1-3 (discussing the lack of obstacles Delaware corporation managers have in erecting defenses to prevent hostile takeovers when they are not selling control of the firm); see Bebchuk, Coates \& Subramanian, supra note 6, at 904-07 (providing evidence that managers who employ poison pills in concert with effective classified boards can fend off hostile offers); Kahan \& Klausner, supra note 65, at 935-36 (discussing the defensive use of "hostile trigger" change of control provisions in bond covenants that impose costs on the target only in the event of a hostile acquisition). Given this discretion, one would expect managers to favor those defenses that deter an unwanted bid at minimal cost, both to the firm and to the managers. We would, therefore, expect managers to employ pure defenses wherever possible. Moreover, given the potential gains to managers of friendly deals under the existing regime, we would expect managers to avoid defenses that deter both friendly and hostile acquisition-unless such defenses provide sufficient compensating benefits in terms of increased firm value. 
regulation. Nevertheless, this Part shows that numerous targeted pre-bid measures exist that would be difficult for courts to regulate. To the extent managers are able to employ these defenses, shareholder choice would do little to achieve increased shareholder control over hostile acquisitions.

Moreover, bringing these close substitutes to pure defenses within the realm of judicial regulation would not eliminate the problems presented by managerial substitution because there are a range of less targeted (and more embedded) defenses to which managers could almost always resort, including blanket defenses that impede friendly and hostile deals alike. Blanket defenses pose a particular challenge for shareholder choice because they are especially likely to serve legitimate, nondefensive business purposes. Thus, they are the least potentially subject to regulation, and yet also are unambiguously more costly to the firm than are pure defenses. While there are few legitimate, nondefensive reasons to condition a corporate transaction on whether a tender offer is hostile, there are many legitimate reasons to condition one on a change of control generally. Moreover, managers' claims that blanket defenses serve a legitimate purpose are enhanced by the price managers pay for adopting them: the deterrence of friendly deals (and perhaps even the altering of the operating structure of the firm).

Accordingly, even under the strongest plausible shareholder choice regime, there is a point of generality at which courts could not efficiently invalidate defensive measures, either ex ante or ex post. ${ }^{70}$ Nor can these defenses be regulated by requiring ex ante shareholder votes on all pre-bid embedded defenses. Shareholders would have to evaluate these transactions in the cool climate of ordinary business, when they have neither sufficient incentives nor capacity to make the complex business decisions entailed in determining whether the benefits associated with a pre-bid defense exceed the expected costs of deterring a potential takeover. ${ }^{71}$

${ }^{70}$ See supra Part I.D (discussing the difficulty of expanding shareholder choice into the fourth quadrant); infra Part II.C.2 (discussing the difficulties of regulating blanket pre-bid embedded defenses).

$"$ See supra Part I.D (discussing the expansion of shareholder power into all preand post-bid defenses). 


\section{B. Retaining Managerial Control over Tender Offers}

Managers subject to a shareholder choice regime that prohibits the preclusive use of pure defenses or post-bid defenses nevertheless could employ a variety of targeted pre-bid embedded defenses to retain control of the tender offer process-deterring hostile bids, while permitting those friendly acquisitions that benefit managers. Courts could easily invalidate some of these targeted pre-bid defenses, but they could not interfere with others without fear of interfering with otherwise legitimate business arrangements. This Section discusses some of these arrangements.

\section{Targeted Defenses Supported by Shareholder Approval}

Under existing statutory authority, managers can alter how the corporation is structured and financed in ways that enable them to retain considerable control over which, if any, takeovers succeed. These defenses are particularly difficult to regulate because shareholders often explicitly approve the power granted to boards to employ these mechanisms. Courts cognizant of legitimate reasons why shareholders might approve such measures could not easily invalidate defensive financing arrangements to which shareholders consent. ${ }^{72}$

For example, managers can retain control over the takeover process through the use of different classes of stock. For instance, management can have the firm issue two types of stock, one of which is publicly traded and the other of which is in the hands of management (or confederates thereof). This latter class would be a strong deterrent to a hostile offer to the extent that consent of a majority of the shares of this class is required for any corporate combination. ${ }^{78}$

${ }^{72}$ Courts could legitimately defer to shareholder approval of defensive capital structures even when such structures-such as dual class common stock or sweetheart preferred-arguably operate as pure defenses if courts conclude that shareholders may have legitimate reasons for granting managers authority over tender offers. These reasons include the fear of substitute defenses discussed here, as well as the possibility that managers may be better able to sell the firm, as discussed in Kahan $\&$ Rock, supra note 13 , at $484-90$.

${ }^{73}$ For example, Ford's Class B stock, which is primarily held by insiders, comprises around four percent of the total shares outstanding, but accounts for roughly forty percent of shareholder voting power. FORD MOTOR CO., 2003 ANNUAL MEETING PROXY STATEMENT 57 (April 28, 2003), available at http://www.ford.com/NR/rdonlyres/ e2wotuuzdzd6yhvdq4nkfubisyvy76mcizsdn4hefx5jkbtuf2epnxg6qiutu2bikh4zqechrl34t p4y6d2bzg2tpnh/2003_proxy_statement.pdf. Coca Cola and General Motors have dual class stock as well. COCA-COLA ENTERPRISES, INC., NOTICE OF 2003 ANNUAL 
Managers can facilitate their ability to use dual class stock by obtaining shareholder approval for "blank check preferred" charter provisions. Blank check preferred stock contains open terms that can be specified by the board at the time it is issued. The vast majority of publicly held firms currently have such charter provisions. ${ }^{74}$ Boards armed with blank check preferred charter provisions can circumvent any shareholder choice regulation of post-bid defenses by issuing defensive preferred stock in the ordinary course of business.

Specifically, managers can employ blank check preferred stock to retain control over tender offers (even under an aggressive shareholder choice regime) by issuing preferred stock with veto rights over any corporate combination and placing a significant amount of the stock in ostensibly independent, but nevertheless "friendly," hands (sweetheart preferred). ${ }^{75}$ Sweetheart preferred stock is a particularly

MEETING OF SHAREOWNERS 4 (2003), available at http://www.shareholder.com/ common/edgar/804055/931763-03-665/03-00.pdf; GENERAL MOTORS CORP., PROXY STATEMENT 1 (2003), available at http://www.gm.com/company/investor_information/docs/stockholder_info/gmpxy/pxy03/Gm03ps2.pdf.

In Europe, firms have employed dual class stock to deter hostile offers by foreign bidders by selling special "golden shares" to the government. Paul Hofheinz, EU Seems Set for a Takeover Makeover, WALL ST. J., June 6, 2002, at A11. For example, until recently, the U.K. government had "golden shares" of at least twenty-six companies. Id. Local city governments, such as London, and other national European governments have also had "golden shares" in important firms. Id. Recently, the European Court of Judges issued a series of decisions that restrict companies' ability to employ golden shares. Id. However, managers retain the ability to adopt a wide variety of protective devices-adopted before a bid is imminent-to thwart takeovers. See Johannes Adolff, Tum of the Tide?: The "Golden Share" Judgments of the European Court of Justice and the Liberalization of the European Capital Markets, 3 GERMAN L.J. 1, I 2 (2002), available at http://www.germanlawjournal.com/article.php?id=170 (noting that golden share arrangements are strictly scrutinized by courts when employed by European Union member states).

${ }^{74}$ In 2000, for example, over ninety percent of publicly listed firms had some form of blank check preferred stock. Investor Responsibility Research Center, at http:// www.irrc.com (last visited Nov. 26, 2003) [hereinafter IRRC database].

${ }^{75}$ Managers can ensure the loyalty of their "sweethearts" through a variety of means: selling to an investor with a well-developed (and profitable) reputation for being friendly to management; inserting contractual provisions that limit defection; retaining the option to call the investor's position; or making profitable side contracts (e.g., consulting deals) which could be lost in an acquisition. Rock, supra note 65, at 1004-05.

Alternatively, preferred stock can be issued with change of control puts, which, for example, enable the holder to redeem the stock at a considerable premium either upon the acquisition by a raider of some threshold ownership amount or upon a change in control of the board following a proxy contest. Such a redemption premium would drive up the cost of any such acquisition, making hostile deals considerably less attractive than friendly ones. The deterrent effect of such provisions can be enhanced to the extent that the firm employs standard debt covenants limiting the 
potent defense given Delaware's antitakeover statute, Section 203, which effectively requires a hostile raider (proceeding without board approval) to obtain approval of at least $85 \%$ of the shares in order to effect a corporate combination within three years of its initial acquisition of at least $15 \%$ of the target's stock. ${ }^{76}$ Thus, management can create a significant impediment to hostile deals by placing even 10$12 \%$ of the voting power in friendly hands. ${ }^{77}$ Moreover, courts would be particularly unable to regulate sweetheart preferred issued stock during the ordinary course of business, for this would entail a determination that certain shareholders are too "management friendly" to be permitted to own certain types of preferred stock. ${ }^{78}$

redemption of capital stock. Moreover, these provisions would be considerably more difficult for a court to invalidate than a poison pill because they grant rights to third parties who presumably paid good value for them. It is likely, however, that preferred stock with "hostile only" change of control provisions would be invalidated by a court pursuing a strong form of shareholder choice. Preferred stock with blanket change of control puts, however, might be more difficult to invalidate. Such blanket provisions are discussed in the next Section. Infra Part II.C.

${ }^{76} 8$ DEL. CODE ANN. tit. 8, $\$ 203$ (2001). Specifically, under section 203 , a raider who acquires $15 \%$ or more of the stock of a company (and becomes an interested shareholder) cannot effect a corporate combination within three years of the acquisition unless (1) the board of the target approved the deal prior to the raider becoming an interested shareholder; (2) the raider acquires $85 \%$ of the outstanding nonmanagement-held voting stock in the initial transaction that made her an interested shareholder; or (3) subsequent to the raider becoming an interested shareholder, the acquisition of the corporation is approved by the target's board and voted for by $662 / 3 \%$ of the outstanding disinterested shares. Id. Managers can reduce the risk of a toehold proxy contest through the use of a staggered board. See Bebchuk, Coates \& Subramanian, supra note 6 , at 890 (explaining that the delay and multiple elections caused by staggered boards render them powerful antitakeover defenses).

${ }^{77}$ See Rock, supra note 65, at 1001 (stating that "a friendly non-management shareholder holding $10 \%$ or so can go a long way towards blocking any hostile tender offer").

For example, in an effort to defend against a hostile bid from Shamrock, Polaroid sold two special series of preferred stock representing approximately $10 \%$ of all votes to Corporate Partners, an investment fund managed by Lazard Freres \& Co. Shamrock Holdings, Inc. v. Polaroid Corp., 559 A.2d 278, 283 (Del. Ch. 1989). Corporate Partners advertised itself as providing insulation from hostile deals, thereby bonding itself to management through its desire to preserve its reputation. Id. at 281. Management further ensured Corporate Partners' loyalty by both retaining the right to call the stock and giving Corporate Partners the right to sell the stock back to the firm for an annual return of $28-30 \%$ should Polaroid be acquired by anyone other than Shamrock. Id. at 284. Faced with voting stock in management-friendly hands, Shamrock abandoned its hostile bid. Rock, supra note 65, at 992. Similarly, Salomon, Gillette, US Airways, and Champion International have each defended against hostile acquisitions by granting significant (8-12\%) voting power to Warren Buffett through the sale of preferred stock (apparently at a discount). Id. at 991-94.

${ }^{78}$ See id. at 1007 (noting that Delaware courts generally have been reluctant to enjoin the issuance of preferred stock in sweetheart preferred cases). 
Managers also can retain considerable control over tender offers by obtaining charter provisions that require supermajority consent for any corporate combination. "Fair price amendments" requiring, for example, approval of the voting power of eighty-five percent of the stock for any combination can significantly increase the costs of an acquisition. $^{79}$ Moreover, such provisions also increase managers' power to control the tender offer process to the extent that either shareholders defer to management's recommendation or managers control a sufficient stake to block a hostile deal.

These are only two of the pre-bid embedded defenses that managers could use to retain considerable control to defeat hostile acquisitions while favoring those that benefit them. ${ }^{80}$ Courts cannot easily regulate these mechanisms, however, as they also may serve legitimate, nondefensive business purposes and often are adopted with shareholder consent. Nevertheless, courts should be wary of creating incentives for managers to substitute into these measures-through adoption of shareholder choice-because the requirement of ante shareholder approval is not sufficient to preclude managers from employing such measures in ways that reduce shareholders' welfare. ${ }^{81}$

${ }^{79}$ While less common than blank check preferred, supermajority and fair price provisions are present in between fifteen and twenty percent of publicly traded firms. IRRC database, supra note 74 .

${ }^{80}$ For example, BAE Systems and Rolls-Royce have employed an alternative approach to thwart hostile tender offers: they limit any single shareholder to ownership of only fifteen percent of the company. Hofheinz, supra note 73, at A12. In addition, BAE requires that half of the board of directors and both the chairman and chief executive officer be British subjects. Id.

${ }^{81}$ This is of particular concern because managers often obtain the requisite approval for such defenses when the firm initially goes public. To the extent that the IPO market is inefficient, managers may obtain authority to adopt such defenses even when they reduce shareholder welfare. See, e.g., Lucian Arye Bebchuk, Why Firms Adopt Antitakeover Arrangements, 152 U. PA. L. REV. 713, 716 (2003) (explaining that when only a minority of pre-IPO shareholders expect to remain with the firm after the IPO, they have an incentive to adopt antitakeover arrangements because they obtain the full benefits of entrenchment but bear only part of the cost of reduced IPO share price); Klausner, supra note 26, at 23 (explaining that managers seek takeover defenses when the resulting expected private benefits are greater than the expected reductions in their shares); $c f$. Bernard S. Black \& Ronald J. Gilson, Venture Capital and the Structure of Capital Markets: Banks versus Stock Markets, 47 J. FIN. ECON. 243, 261 (1998) (asserting that venture capitalists can motivate entrepreneurs ex ante by promising to exit through an IPO should the company succeed, and noting that exit is made all the more valuable by defensive charter provisions insulating the entrepreneur from a hostile acquisition).

Moreover, even after the shares are initially sold, corporate governance arrangements may still be inefficient and nonetheless be approved by shareholders. See 
Yet, even so, courts should be wary of overriding the results of a shareholder vote since they most likely do not possess sufficient information to determine what course of action shareholders should have taken. ${ }^{82}$

\section{Targeted Defenses Not Requiring Shareholder Approval}

Managers also can retain considerable control over tender offers through mechanisms that do not require shareholder approval. For instance, managers can structure spin-offs and strategic acquisitions to deter tender offers. As an example, a company can deter bids by placing the firm's most valuable operating assets (or crown jewels) in a spin-off subsidiary governed by a voting trust. In this case, even if the board of the subsidiary changes, control of the voting trust does not. $^{83}$ Although courts may readily subject such measures to shareholder oversight when adopted post-bid-when shareholders' decision-making capacity is at its peak-they cannot do so when they are adopted in the course of ordinary business when courts cannot rely on shareholders to assess their validity.

Management also may be able to structure its own contracts in order to impose significant costs on hostile raiders. This can be achieved, for example, by incorporating change of control provisions in their employment contracts that permit managers to leave immediately upon a change of control with substantial severance packages. ${ }^{84}$

Bebchuk, supra, at 11-15 (arguing that shareholders may approve provisions granting boards control over takeovers that are inefficient).

${ }^{82}$ This is particularly the case to the extent that shareholders may conclude that firm value is higher when managers have control over tender offers (both for the reasons given in this Article and for others). See, e.g., Kahan \& Rock, supra note 13, at 18 (arguing that managerial control may increase value because managers are better able to implement a selling strategy).

${ }^{83}$ See Thompson v. Enstar Corp., No. 7643, 1984 WL 8240, at *5 (Del. Ch. June 20, 1984) (upholding Enstar's lockup of a deal with Unimar by giving it voting control of its most valuable asset, Enstar Indonesia, through use of a voting trust, irrespective of whether a larger corporate combination is consummated).

${ }^{84}$ Managers' power to influence bids could be particularly strong if they act in concert, threatening a hostile bidder with a mass exodus (the so-called "Jonestown defense"). See Leonard I. Reiser, Comporate Takeovers: A Glossary of Terms and Tactics, CASE \& COM., Nov.-Dec. 1984, at 35, 44 (describing the Jonestown defense as a suicidal tactic on the part of managers of the target company). An acquirer faced with a mass exodus of management may be unwilling to proceed with a hostile bid even if it had planned to fire management eventually because acquirers often need existing management to train new management. Moreover, shareholders may be unwilling to approve a corporate combination if faced with a potential mass exodus because they know they would suffer greatly if the merger were approved (triggering managerial 
In addition, managers may be able to entrench themselves through measures that accentuate their idiosyncratic value to the firm. ${ }^{85}$ For example, managers may be able to set up organizational structures, establish internal lines of communication, and implement corporate cultures that depend critically on their own managerial skills. By making themselves more valuable to the firm, managers may be able to influence which acquisitions succeed by agreeing to work for some acquirers post-acquisition and refusing to work for others. ${ }^{86}$

Finally, managers can discourage hostile bidders by refusing to share private information (or by doing so only grudgingly). Private information is particularly important for companies with numerous

exit) yet never completed. Cf. John C. Coates IV \& Guhan Subramanian, A Buy-Side Model of MËA Lockups: Theory and Evidence, 53 STAN. L. REV. 307, 347 (2000) (finding that $24 \%$ of negotiated mergers agreed to between 1988 and 1999 were not completed when there was no lockup or breakup fee, and that even when there was both a lockup and breakup fee, $5.3 \%$ of such deals were not completed).

Hostile bidders could, of course, reduce managers' incentives to employ this defense by offering appropriate incentives for managers to remain. Yet this does not eliminate the problem created by the threat of managerial exodus. The amount managers could extract from a hostile raider to induce them to remain would reduce the hostile bidder's incentive to bid (by increasing costs) and enable managers to appropriate some of the gains from the deal as private benefits.

${ }^{85}$ Thus, for example, an acquirer considering an acquisition of Donna Karan International would be unlikely to attempt a hostile acquisition given that Donna Karan's own employment contract is terminable upon a change of control. Donna Karan International Inc. Prospectus, SEC Reg. No. 333-3600, at 76 (June 28, 1996).

${ }^{86}$ See, e.g., Andrei Shleifer \& Robert W. Vishny, Management Entrenchment: The Case of Manager-Specific Investments, 25 J. FIN. ECON. 123, 123-24, 134-36 (1989) (arguing that managers can entrench themselves by pursuing projects they are particularly wellsuited to manage, even when these are not profit maximizing); see also Aaron S. Edlin \& Joseph E. Stiglitz, Discouraging Rivals: Managerial Rent-Seeking and Economic Inefficiencies, 85 AM. ECON. REV. 1301 (1995) (explaining that managers can discourage potential challengers through investments that increase rivals' perceived uncertainty about the firm's prospects).

Although it is difficult to garner hard evidence about the degree to which firms engage in such practices, a recent study of employee involvement in Fortune 1000 firms is suggestive. EDWARD E. LAWLer III ET Al., ORGANizing fOr High PerformANCE 21-26 (2001). From 1987 though 1996, while overall hostile acquisition activity was ebbing in the wake of Delaware's antitakeover statute, firms became increasingly likely to involve their employees in quasi-managerial power and information-sharing practices. Such programs include job enrichment or redesign programs, selfmanagement teams, mini-business units, and employee policy committees. Id. at 48-53. During the late 1990s, however, as hostile bid activity began to approach its pre-1987 levels, such employee management initiatives fell from favor, decreasing in frequency to their pre-statute levels. Id. One interpretation of this trend (though certainly one of many) is that the credible threat of hostile acquisitions gives managers an incentive to centralize information management and decision-making authority in order to make the managers indispensable. 
off-balance sheet arrangements and for companies whose value depends to a considerable degree on the results of new initiatives (for example, new drugs).

\section{Impediments to All Changes of Control}

Even if the problems posed by managerial substitution into targeted pre-bid embedded defenses can be redressed through more stringent regulation of any measure that grants boards control over tender offers, this would not solve the challenge posed by pre-bid embedded defenses. Even if courts could preclude the use of any and all targeted pre-bid embedded defenses, managers could employ blanket pre-bid embedded measures that impede all types of acquisitions, hostile or otherwise. These measures could impose much greater costs on the firm, potentially leaving shareholders wistful for the days of the poison pill. Moreover, shareholder choice may provide managers with incentives to employ such defenses, notwithstanding the obvious cost to managers of the resulting reduction in friendly deals. ${ }^{87}$ As many of these measures currently serve important and legitimate (nondefensive) business purposes, courts could not prohibit the use of such measures without assuming excessive managerial authority over publicly held firms' business transactions or doing violence to the foundational precept of managerial authority over ordinary business transactions.

\section{Change of Control Provisions in Third-Party Agreements}

Managers precluded from employing targeted defenses could nevertheless entrench themselves by erecting barriers to acquisitions generally. One way to do this would be to insert change of control provisions in the firm's contractual arrangements with third parties. Change of control provisions can be-and currently areincorporated into a variety of contracts, including intellectual property licenses, leases, joint ventures, debt and equity financing, union contracts, and employee stock option plans. ${ }^{88}$ These provisions

${ }^{87}$ Compare infra Part IV.C.2 (showing that shareholder choice can induce managers to employ value-reducing blanket defenses that they would not employ under a managerial choice regime), with Gilson, supra note 40, at 887-90 (arguing that the risk of substitution from post-bid defenses to untargeted pre-bid defenses is not particularly significant because managers will eschew such untargeted pre-bid defenses because they are too costly for managers).

${ }^{88}$ See supra note 75 (discussing change of control provisions in preferred stock). 
generally either terminate the contract or impose a penalty on the target in the event of a change of control or corporate combination, ${ }^{89}$ friendly or otherwise. ${ }^{90}$

Change of control provisions are difficult to regulate because they generally are adopted well in advance of a tender offer, and they serve the important, legitimate (nondefensive) purpose of protecting thirdparty interests (thereby facilitating certain welfare-improving transactions). ${ }^{91}$ Third parties contracting with firms often have good reasons

Although there is not, to our knowledge, a reliable database detailing all variations on change of control provisions, in 2000 nearly two-thirds of all publicly traded firms had some sort of provision in their employment contracts or collective bargaining agreements. IRRC database, supra note 74.

${ }^{89}$ Change of control provisions vary in how they define the triggering event. Managers can draft them to ensure that they cover any transaction a hostile raider might wish to accomplish.

${ }^{90}$ In this Section, we focus on blanket change of control provisions. Nevertheless, if courts failed to regulate all targeted defenses, managers could instead employ change of control provisions that are triggered solely by a hostile change of control: for example, an acquisition not preceded by board consent or a change in the majority of the board in a single year. Such a provision would, in effect, replicate the effects of the poison pill. Indeed, managers regularly employed "hostile trigger" change of control provisions prior to embracing the poison pill and classified board.

Analysis of bond covenants employed in the late $1980 \mathrm{~s}$ and early $1990 \mathrm{~s}$ reveals that, prior to the RJR Nabisco leveraged buyout, almost all bonds contained covenants that encumbered only hostile takeovers and proxy contests, usually without regard to their effect on bond values. Kahan \& Klausner, supra note 65 , at 970, 970-72. While management subsequently reduced their use of such hostile trigger covenants in the late $1980 \mathrm{~s}$, id. at 974 , the history of hostile trigger change of control provisions reveals managers' willingness and ability to employ such provisions as substitute defenses. One would expect the adoption of shareholder choice to cause managers to reembrace hostile trigger debt covenants if permitted to do so.

Hostile trigger debt covenants are potentially even more effective entrenchment devices than are pure poison pills (unassociated with a classified board). Shareholders cannot use proxy contests to circumvent these measures because these provisions often are written so that a successful proxy contest itself triggers the change of control penalty. See id. at $937-43$ (describing debt covenants with this feature). Thus, they significantly increase the expected cost to shareholders of voting for a deal, even if the acquirer is willing to proceed notwithstanding the penalty. Hostile trigger covenants raise the risks to shareholders of proceeding with a hostile deal because shareholders recognize that they could potentially bear the full penalty with no resulting gain should the acquirer fail to consummate the deal following a shareholder vote to oust the board. Id.

${ }^{91}$ The latter makes such contracts more difficult to invalidate than lockups, for example, because the primary purpose of a lockup is to favor one bidder over another. To the extent one accepts shareholder primacy post-bid, shareholders should determine which bidder to favor. Shareholders cannot, however, assess the merits of change of control provisions in pre-bid contracts-at least not if the presumptions underlying title 8, section 141 (a) of the Delaware Code and the business judgment rule are correct. 
for insisting on change of control provisions. Many contracts are long-term and, thus, necessarily incomplete. In such cases, the value of the contract depends critically on the trustworthiness and reliability of the contracting party. In addition, a party granting a license may seek to protect its own market position by seeking to control the identity of those who use its license. For example, the party may want to ensure that a competitor does not obtain the license. Accordingly, a contracting party may value highly the ability to protect itself from changes in the identity of the other party to the contract through a change of control provision that allows the third party to terminate the contract should the other party's management change. Granting such a provision can increase the joint benefits of the contract to both parties.

In some circumstances, simple termination of the contract may not fully eliminate the potential harm to the third party of a change of control. In these circumstances, third parties also may legitimately insist on a "penalty" change of control provision, which grants a benefit to the third party (at the expense of the target) in the event of a change of control. For example, the holder of an intellectual property right licensed to a firm may suffer damage should a competitor purchase the licensee firm, even if the change of control terminates the license. Through purchase of the licensee, the competitor necessarily obtains considerable proprietary information about the licensor's intellectual property. To redress the costs to the licensor of this eventuality, it may legitimately insist on a penalty change of control.

The claim that both termination and penalty change of control provisions may serve legitimate (nondefensive) business purposes (thereby benefiting shareholders) is supported by evidence, presented below, that firms currently employ such change of control provisions, burdening friendly and hostile deals alike. Under current law, generally managers have little reason to employ such measures for entrenchment purposes because they can deter hostile deals through other means that do not also discourage friendly deals. Thus, when managers do employ such measures, they generally are doing so for nonentrenchment reasons-because the third party insisted on the provision, and managers concluded that the expected benefit of including it exceeds the expected cost. Accordingly, courts could not simply prohibit such measures categorically without adverse consequences for certain firms.

Such measures present a challenge for proponents of shareholder choice because, under shareholder choice, managers could easily use 
change of control provisions to entrench themselves. ${ }^{92}$ Moreover, managers employing such provisions for entrenchment purposes often would reduce firm value, even if they employed provisions ostensibly identical to those that enhance value in other circumstances, if shareholder choice motivated managers to use change of control provisions in situations where they do not significantly reduce the firm's costs of contracting with third parties.

\section{a. Termination clauses}

The simplest change of control provisions give a third party the right to terminate the contract upon a change of control. For example, many intellectual property licenses, joint venture agreements, and leases have change of control provisions that terminate the licenses upon change of control. ${ }^{98}$

Termination clauses are a particularly effective takeover deterrent in those circumstances where the target can rely on the third party not to assign the contract to the acquirer at the original price. Managers can rely on third parties either to terminate the contract or to impose significant additional costs in return for a new contract in at least three situations.

First, the third party will not assign the contract to an acquirer under its existing terms when the contract has become substantially more valuable than when originally signed. For example, a firm with a long-term license to a product issued at an early stage in the development process (e.g., a drug) may find itself with an extraordinarily valuable license once the true value of the product is known. Should the license have a change of control termination clause, the firm may be more valuable as a stand-alone entity than acquired because, if the firm is acquired, the licensor can use the threat of license termination to renegotiate the license to grant it those rents from the product that otherwise would have gone to the licensee. In this situation, the firm may be most valuable unacquired.

${ }^{92}$ At present, managers often draft change of control provisions as narrowly as possible so that many do not cover all corporate combinations a hostile raider might seek to implement. Should courts implement a strong shareholder choice regime that precludes the use of targeted defenses, managers can be expected to implement broader change of control provisions that deter acquisitions.

${ }^{93}$ Indeed, even without a change of control provision, many licenses are presumed to terminate in the event of a merger where the acquirer is the surviving firm. See Elaine D. Ziff, The Effect of Corporate Acquisitions on the Target Company's License Rights, 57 BUS. LAW. 767, 783-87 (2002) (discussing the termination of trademark and patent licenses in the context of forward mergers). 
Second, third-party beneficiaries of a change of control provision also can be relied upon to terminate the contract when the third party competes with the firm's potential acquirers. ${ }^{94}$ Indeed, examples exist currently where such provisions have impacted takeovers.

For example, John Labatt Ltd., Canada's second largest beer manufacturer, apparently fended off a hostile offer by Onex Corp., in part through the use of partially disclosed third-party contracts and licenses terminable upon a change of control for Labatt. These thirdparty agreements included the Canadian Budweiser license and the license for the Mexican brewer, FEMSA Cerveza SA. ${ }^{95}$

At one point, efforts to acquire Hershey Foods Co. (Hershey) were hindered in part by a change of control provision in Hershey's license from Nestle SA, granting it the right to manufacture and sell KitKat, one of the most popular chocolate bars in the world. Nestlé has looked unfavorably on attempts to acquire Hershey, which could improve Hershey's competitive position and at one point threatened to terminate its license in the event Hershey experiences a change of control. ${ }^{96}$

Finally, certain managers (for example, founding shareholders) can use their own licensing agreements with the firm to grant them

${ }^{94}$ Likewise, companies can use joint ventures with other firms in the same industry that terminate upon a change of control to impede acquisitions by other firms in the industry. Parties to a joint venture also can deter bids by including noncompete agreements in the venture, which would prohibit either the company or an affiliate from competing without termination of the respective company's rights under the venture. Such provisions can be used to deter acquisition of the firm by companies in the same industry as the venture.

${ }_{95}$ Larry M. Greenberg, Onex Pressures Labatt to Disclose Third-Party Pacts, WALL ST. J., May 25, 1995, at C15.

${ }_{96}$ See Gordon Fairclough \& Erin White, Shake-Up in Candyland, WALL ST. J., July 26, 2002, at B1 (describing the Nestlé deal). The Nestlé deal is not the only impediment to the sale of Hershey. The sale also has been impeded by the political objectives of Hershey Trust Company, the major Hershey shareholder. See Robert Frank \& Sarah Ellison, Meltdown in Chocolatetown, WALL ST. J., Sept. 19, 2002, at B1 (describing the Hershey Trust Company's rejection of a sale of Hershey in response to public pressure).

Of course, existing change of control termination clauses in contracts with competitors do not always deter acquisitions. Yet, those acquisitions that proceed in the face of existing change of control provisions do not undercut our claim that such provisions could be used defensively. At present, managers do not try to maximize the defensive effect of change of control provisions because they have superior, lower-cost defenses available to them. See supra text accompanying notes 69-71 (arguing that managers have little reason to employ pre-bid embedded defenses because they can employ lower-cost pure defenses). Under shareholder choice, managers would alter these provisions. 
effective control over any acquisition. For example, rather than grant valuable intellectual property to the firm outright, a founding shareholder can license the property to the firm with a contract that provides for termination of the license upon change of control. Donna Karan International is an example of a firm that has employed this type of defensive measure. ${ }^{97}$ When the company went public in 1996, Ms. Karan and her husband retained control of the trademarks for most of the product lines-including "Donna Karan," "Donna Karan New York," "DKNY," and "DK"-under a wholly owned corporation, Gabrielle Studio. ${ }^{98}$ Gabrielle Studio then licensed the trademarks to Donna Karan Corporation, with a provision terminating the license in the event of a change of control of Donna Karan Corp. The employee contract with Donna Karan also terminates upon change of control. This grants her effective authority to determine whether the firm is sold, and to whom, because most of the firm's goodwill would evaporate upon any change of control done absent Ms. Karan's explicit consent. ${ }^{100}$

\section{b. Penalty provisions}

Managers need not restrict themselves to change of control provisions that simply terminate the contract. In addition, they can obtain protection from acquisitions by employing change of control provisions that require the firm to confer substantial benefits to the third party in the event of a change of control: clauses we refer to as "penalty" change of control provisions. If large enough, these penalties can substantially insulate managers from acquisitions.

Penalty change of control provisions serve legitimate purposes in certain situations and, thus, should not be prohibited categorically. Penalty provisions may improve the joint welfare of contracting parties when third parties can expect to suffer losses in the event of a change of control of a contracting party even if the contract is terminated.

Third parties may be injured by a change of control even if they terminate the contract when acquirers can use the information the target gained from contracting with the third party to compete against

${ }^{97}$ Donna Karan International Prospectus, supra note 85 , at 76.

${ }^{98}$ Id.

${ }^{99}$ See id. (defining change of control as the purchase by a third party of thirty percent of the stock of Donna Karan International); see also Wendy Bounds, Donna Karan International's Slip is Beginning to Show, WALL ST. J., May 8, 1997, at Bl (describing Ms. Karan's licensing agreement and its implications).

${ }^{100}$ Donna Karan International Prospectus, supra note 85, at 76. 
the third party. In such cases, third parties may legitimately insist on being paid additional remuneration upon a change of control in order to protect their interests.

Third parties also may insist on penalty provisions where terminating the contract is likely to be the optimal response to a change of control, and yet would leave the third party worse off than if no change of control occurred. Accordingly, to protect themselves from substantial potential costs associated with a change of control, third parties may reasonably insist on change of control provisions that give them the right to terminate the contract on favorable terms: terms that confer a benefit on the third party and a penalty on the contracting firm. ${ }^{101}$

At present, firms incorporate penalty change of control provisions into a variety of contracts, including debt contracts, leases, licenses, union agreements, and joint ventures. Although many existing penalty change of control provisions are value enhancing, managers subject to shareholder choice could readily employ such provisions defensively, at shareholders' expense. An examination of existing penalty change of control provisions reveals their potential as defensive measures should managers ever need to exploit them more aggressively than they do at present. ${ }^{102}$

Firms currently employ penalty change of control provisions in basic financing arrangements, such as debt contracts. For example, non-investment-grade debt contracts often contain change of control provisions that give the creditor the right to transfer her bonds back to the issuer at a premium upon a change of control. By incorporating such penalties into all debt contracts, managers could employ these and other similar provisions to substantially increase the costs of acquisitions. Indeed, in previous periods, managers have used penalty change of control provisions in debt covenants to deter acquisitions. ${ }^{103}$

${ }^{101}$ Notwithstanding the general judicial disfavor of contractual penalties, courts generally enforce these penalty change of control terms. First, the plausible thirdparty losses that attend a change of control usually consist of lost profit streams that are extremely difficult to quantify, thereby substantially increasing the chances that the stipulated term will be enforceable. Second, these terms often are drafted to hide the penalty provision. For example, the penalty clauses in joint venture agreements often simply state the price at which the third party can purchase the joint venture, without specifying the degree to which this price is below the fair market value of the venture.

${ }^{102}$ Indeed, the poison pill is one form of penalty change of control provisions. Should courts preclude managers from using the pill, managers could incorporate penalty provisions of a similar magnitude into other contracts, such as debt contracts.

${ }^{103}$ Analysis of bond covenants reveals that managers have altered the structure of these covenants over time to operate more or less as entrenchment devices depending 
Managers also can, and do, incorporate penalty change of control provisions into joint venture agreements. Joint venture agreements often contain change of control provisions that grant to one party the right to buy the other's interest in the venture upon a change of control by the latter; these provisions can operate as penalty provisions by setting a buyout price that is less than fair market value. In this case, a change of control of the target can result in the target losing a substantial portion of the value of the joint venture upon a change of control. If the joint venture is profitable enough and the penalty large enough, these provisions can deter an acquirer. The penalty also reduces the value to target shareholders of any deals that do proceed.

The joint venture between Schering-Plough Corp. and Merck \& Co. appears to contain such a penalty change of control provision. In the shadow of speculation that it was ripe for a hostile bid, ScheringPlough entered into a joint venture with Merck to cooperate in the development and marketing of a new anticholesterol drug, Zetia, a drug many concluded was Schering-Plough's best hope for future profits. ${ }^{104}$ The agreement provides that, if a third company bought Schering-Plough, Merck could purchase Schering-Plough's interest in the joint venture at an unspecified price, which could not equal the actual value of the venture. ${ }^{105}$ Given that Zetia appeared to be Schering-Plough's best hope for future profits, the joint venture agreement effectively discouraged bids. ${ }^{106}$

Similarly, the joint venture between Wackenhut Corrections Corp. and Serco Investments Ltd. grants Serco the right to buy out Wackenhut's interest in the joint venture for less than its fair market value in

in part on the availability of alternative defenses. For example, almost all of the bonds issued prior to the RJR Nabisco leveraged buyout contained terms that encumbered only hostile takeovers and proxy contests. These terms helped entrench managers, while providing little real protection to bondholders. Kahan \& Klausner, supra note 65, at 970-72. Managers moved away from entrenchment-oriented debt covenants after they embraced the poison pill, and with the decline in takeover activity in the early 1990s. See id. at 980.

${ }^{104}$ Peter Landers, Merck Sacrificed Right to Make Buyout Offer to Schering-Plough, WALL ST. J., Oct. 22, 2002, at B3.

${ }^{105}$ The price is to be determined after any change of control by two investment banks without ties to the companies. Id. This raises the cost to an acquirer of bidding for Schering-Plough because the acquirer cannot easily determine the appropriate purchase price for Schering-Plough without knowing what value the investment banks will place on the Schering-Plough/Merck joint venture.

${ }^{106}$ Id. 
the event of a change of control of Wackenhut. ${ }^{107}$ Other examples abound. ${ }^{108}$

Managers also can incorporate penalty change of control provisions into licensing agreements. For example, in response to a hostile offer by Oracle Corp., PeopleSoft, Inc. employed a penalty change of control provision in its licensing fee agreements with customers. Under this provision, PeopleSoft offered its software licensees a refund of between two and five times their licensing fees if, within four years of a change of control, the acquirer reduced investment in research and development and customer support. ${ }^{109}$ The resulting penalty of $\$ 800$ million (by current estimates) is sufficiently large that Oracle announced that it could not proceed with its bid if PeopleSoft continued to offer such refunds. ${ }^{110}$ While the specific provision in PeopleSoft

${ }^{107}$ See Robin Londner, Latest News, Wackenhut Corrections to Sell U.K. Venture, S. FLA. BUS. J., May 8, 2003, at http://www.bizjournals.com/southflorida/stories/2003/05/ 05/daily56.html (mentioning the dispute between Wackenhut and Serco concerning Serco's right to buy Wackenhut's joint venture interest).

Penalty joint venture clauses also impacted Guinness's merger with GrandMet. A third party, Moèt Hennessy-Louis Vuitton (LVMH) claimed that the merger triggered change of control clauses in its joint ventures with Guinness. Alasdair Murray, LVMH Move Threatens £23bn Guinness Merger, TIMES (London), May 29, 1997, at 25. These change of control provisions allowed LVMH to buy back Guinness's stake in its seventeen joint ventures at asset value in the event Guinness experienced a change of control; they also entitled LVMH to buy Guinness's thirty-four percent stake in Moët Hennessy at a discount of up to fifteen percent. Id. In return for a payment from Guinness of 250 million pounds, LVMH eventually agreed to withdraw its effort to block the merger. Major Obstacle Cleared in (pounds) $24 b n$ Guinness Deal, IRISH TIMES, Oct. 14, 1997, at 18. Had LVMH pursued its claim in arbitration, the firm stood to gain as much as one billion pounds had it prevailed. Id.

${ }^{108}$ There are many examples of penalty change of control provisions embedded within joint venture agreements. For example, Pacific Dunlop (PacDun) included a change of control provision in its South Pacific Tyres joint venture with the Goodyear group that granted each partner the right to buy out the other in the event of a change of control. Under the sale price formula to be employed, Goodyear would need to pay PacDun only about half the value of PacDun's share of the joint venture should PacDun be subject to a change of control. Malcolm Maiden, PacDun: Deliver or Else, Sydney MoRning Herald, Oct. 30, 1999, at 97. Another example is WMC Ltd., an Australian mining company with aluminum assets, which created an impediment to any effort to sell the firm by inserting a change of control provision in its joint venture with Alcoa World Alumina and Chemicals (AWAC). The joint venture agreement required any acquirer with aluminum assets who took control of WMC to insert its aluminum assets into the AWAC joint venture. As a result of this agreement, when the WMC board decided to solicit an acquisition, it determined that it would need to split WMC in two in order to sell to anyone other than AWAC. Kate Askew, PM and Mrs. Lob At Jonesy's Chrissy Do, SYDNEY MORNING HERAL.D, Dec. 13, 2001, at 25.

${ }^{109}$ David Bank, Oracle May Drop Bid for PeopleSoft Over Refund Offer, Wall. ST. J., Nov. 11,2003 , at B4.

${ }^{110}$ Id; Chris O'Brien, PeopleSoft Allers its Rebate Program, SAN JOSE MERCURY NEWS, 
may be vulnerable to court challenge in part because it was adopted post-bid, managers seeking to deter hostile offers could adopt similar provisions in the ordinary course of business. Such actions would almost certainly be entitled to business judgment rule protection, since such customer protection provisions in customer service agreements arguably enhance firm value by guaranteeing the long-term quality of the product. ${ }^{111}$

\section{Change of Control Provisions Under Shareholder Choice}

Accordingly, were courts to embrace a strong form of shareholder choice-regulating all post-bid and targeted defenses-managers could entrench themselves nonetheless by making much greater use of penalty change of control provisions. Moreover, managers could increase the deterrent effect of these provisions by employing large penalties-justifying the higher penalties through the greater need to protect third parties from the increased risk of tender offers under shareholder choice. Managers could further strengthen the entrenchment effect of these measures by inserting them into many separate types of contracts, including debt contracts, customer agreements, employment agreements, licenses, and joint ventures. Inserting change of control provisions in a variety of contracts could increase both the magnitude of, and the uncertainty surrounding, the total penalty resulting from a change of control. A firm employing penalty change of control provisions in a variety of nonmaterial contracts could increase bidder uncertainty by publicizing that such provisions exist, while refusing to disclose their precise value. ${ }^{12}$

Nov. 20, 2003, at 3C (describing how potential liability for refunds has risen to $\$ 800$ million).

"II Id. Among Oracle's original claims were that the PeopleSoft provisions are invalid because they potentially impose a change of control penalty on PeopleSoft even upon a change of control of the PeopleSoft board if it is not supported by the existing board. This aspect of the provision arguably infringes on shareholders' franchise. On November 17, however, PeopleSoft retracted the provision treating a change in the board as a "change of control," describing the original decision to adopt such a broad provision as an "administrative error." Mark Veverka, PeopleSoft: A Wolf in Sheep's Clothing, TORONTO STAR, Nov. 24, 2003, at D4. Whatever the eventual fate of PeopleSoft's revised licensing agreement, managers could no doubt implement similar change of control provisions in the ordinary course of business that are effective and yet avoid any problems the courts may find with the PeopleSoft provisions.

${ }_{112}$ The board need not disclose the terms of immaterial contracts. Managers thus can create impediments to hostile bidders by including change of control provisions in each of their non-material third-party contracts, and disclose the existence of such provisions but not their terms. Managers could thereby entrench themselves by using 
Penalty provisions are effective in part because they are relatively resistant to Coasean renegotiation: the acquirer would necessarily have to involve a third party, providing her with sufficient compensation to offset her foregone opportunity to receive the penalty. This, in and of itself, would increase acquirers' costs. Moreover, acquirers may be unable to renegotiate penalty change of control provisions if firms employ such provisions in many contracts, or in contracts involving numerous parties (such as debt securities). ${ }^{113}$ In such situations, renegotiation may be prohibitively expensive in terms of the time, effort, and collective action problems that often attend multi-party bargaining when each party has an incentive to hold out for a disproportionate share of the joint gains. ${ }^{114}$ Finally, managers can further impede bargaining by inserting such provisions in contracts with parties who could be hurt by the acquisition (e.g., creditors, employees, or competitors).

Managers would enjoy considerable discretion to expand their use of change of control provisions because neither courts nor shareholders can confidently regulate them. Courts cannot simply invalidate all penalty change of control clauses because many are used to enable the firm to enter into value-enhancing contracts by protecting legitimate interests of contracting parties. ${ }^{115}$ Courts, therefore, could not prohibit such measures categorically absent clear proof that the benefits of legitimate change of control provisions are dwarfed by the cost of permitting firms to use these provisions defensively. The existing evidence on the widespread use of such provisions suggests courts should be wary of reaching such a conclusion. The use of such provisions, notwithstanding management's access to low-cost defenses such

the combined effect of these provisions to increase both the potential costs of acquiring the firm and potential bidders' uncertainty about the value of the target. $C f$. Edlin \& Stiglitz, supra note 86, at 1302 (discussing how managers can entrench themselves using measures that increase acquirers uncertainty concerning firm value).

${ }_{113}$ For example, poison pills are themselves penalty change of control provisions. We are not aware of any bidder attempting to circumvent a pill by negotiating with all shareholders for them to relinquish their rights under the pill in return for the acquirer proceeding with the bid.

114 See generally ROBERT COOTER \& THOMAS ULEN, LAW AND ECONOMICS 81-90 (3d ed. 2000) (describing transaction costs presented by multi-party bargaining).

${ }^{115}$ See supra text accompanying notes $91-92$ and notes 100-01 (discussing the benefit of change of control provisions in third-party agreements); see, e.g., Kahan \& Klausner, supra note 65 , at $937-40$ (discussing how change of control provisions in bonds can benefit the firm). 
as the poison pill and classified boards, lends credence to the claim that these provisions serve legitimate goals. ${ }^{116}$

Nor can courts prohibit only value-reducing change of control provisions. Courts cannot reliably distinguish legitimate, valueenhancing change of control provisions from value-reducing provisions that serve primarily entrenchment aims. ${ }^{17}$ Thus, courts cannot effectively regulate these measures either ex ante or ex post after a bid has been announced. ${ }^{118}$ Nor can courts prevent the use of valuereducing pre-bid change of control provisions by insisting that shareholders consent to such contracts. As noted above, shareholders are not sufficiently informed to oversee the terms of ordinary business transactions reliably, a proposition proponents of shareholder choice themselves readily concede. ${ }^{119}$ Indeed, evaluating change of control

${ }^{116}$ For a possible explanation of why managers might not employ optimal takeover defenses, see John C. Coates IV, Explaining Variation in Takeover Defenses: Blame the Lawyers, 89 CAL. L. REV. 1301 (2001).

${ }^{117}$ Although it might appear that courts can identify entrenchment provisions based on whether the provision was proposed by management or a third party, this is not the case. A manager may propose a value-enhancing change of control provision if she concludes that she can obtain a better agreement as a result. In addition, at present third parties regularly seek such provisions; what determines whether the agreement contains such a provision is whether third parties meet resistance from managers. Managers, thus, could increase their use of penalty change of control provisions simply by acceding to third parties' requests for them.

${ }^{118}$ Ex post scrutiny by courts or shareholders would undermine the value of many of these arrangements by leaving their validity uncertain. This would reduce the value of those firms that benefit from adopting such measures.

Thus, arguments favoring court oversight of redeemable poison pills do not apply to their cousins, change of control provisions. Penalty change of control provisions are less amendable to shareholder oversight than are redeemable poison pills. In theory, courts can retain any benefits of poison pills, while muting their adverse effects, by requiring boards to submit all bids to the shareholders for a vote and redeem any pill affecting a shareholder-approved acquisition. By contrast, courts cannot use shareholder voting to undo the entrenchment effect of change of control provisions without also eliminating the benefits of these provisions because change of control provisions generally impose costs on the target firm in the event of a change of control, even if shareholders approve the deal. Courts, therefore, cannot remove the entrenchment effect of these provisions by invalidating penalties whenever shareholders approve the deal, because third parties seek protection from shareholder-approved deals. Thus, ex post invalidation would hinder firms' abilities to employ these provisions when they are value enhancing.

${ }^{119}$ Corporate scholars have suggested that ordinary shareholders may not have sufficient incentive and capacity to make even the simplest decisions associated with shark repellent amendments. Further, these scholars argue that sophisticated shareholders may not intervene aggressively if they expect it to be too expensive to inform unsophisticated investors. See Gilson, supra note 22, at 822-27 (claiming that shareholders approve shark repellent amendments contrary to their own self-interest 
provisions would challenge the capacity of both ordinary and sophisticated shareholders ${ }^{120}$ because the nature and effects of these provisions are firm-specific-and even contract-specific. Thus, analysis of any one provision would not necessarily enable shareholders to assess any other, even when adopted by the same firm.

Accordingly, managers subject to a shareholder choice regime that regulates all targeted defenses could entrench themselves by using blanket pre-bid embedded defenses, such as penalty change of control provisions. ${ }^{121}$ Increased use of such defenses could adversely affect the number of acquisitions, friendly and hostile alike. As the vast majority of deals currently are friendly acquisitions, any legal reform that might deter such acquisitions could reduce the welfare of target shareholders.

\section{Pre-Bid Measures Granting Managers Private Benefits}

Managers can employ pre-bid measures not only to deter potential acquisitions, but also to guarantee that they obtain substantial private benefits from any acquisitions that do occur. Managers can guarantee themselves substantial private benefits from acquisitions through

because unsophisticated shareholders are not adequately informed and sophisticated shareholders find it too costly to intervene to inform unsophisticated shareholders).

${ }^{120}$ Institutional shareholders have evinced a preference for analyzing corporate governance issues common to many firms, instead of measures (such as change of control provisions) whose effects are corporation-specific.

Shareholders' inability to exercise ex ante oversight over change of control provisions also implies that shareholders could not effectively use the threat of a proxy contest to deter managers from implementing value-reducing change of control provisions. Shareholders cannot be relied on to dislodge managers who have adopted value-reducing change of control provisions if they cannot determine which change of control provisions are, in fact, value reducing. See supra Part I.D.2 and note 67 (discussing why shareholders cannot rely on proxy contests to optimally deter managers' use of these defensive measures).

Moreover, even if shareholders were sure that managers had adopted a valuereducing change of control provision, they might be unwilling to respond by mounting a proxy contest to replace management. First, depending on how the change of control provisions are written, a successful proxy contest itself may trigger the change of control provision. See Kahan \& Klausner, supra note 65, at 937-43 (describing debt covenants with this feature). Second, shareholders may have little to gain from such a proxy contest since blanket change of control provisions generally are not redeemable by the board. Thus, shareholders of firms with strong change of control provisions may not be able to make the firm more takeover-friendly by changing management. Thus, management's adoption of such provisions will not necessarily provide shareholders with an incentive to replace management. See supra note 67.

${ }^{121}$ Indeed, the poison pill itself is an example of a substitute defense invented to circumvent efforts to regulate prior defenses, such as selective self-tenders. 
the use of change of control provisions in executive compensation agreements (e.g., golden parachutes). Typical executive compensation arrangements provide that on a change of control, senior management receives severance pay equal to three years salary, bonuses, and options. ${ }^{122}$ In addition, the change of control often triggers the vesting of the executives' stock options. Managers can use these severance packages to guarantee themselves substantial private benefits in the event of a change of control.

While in theory these packages could become sufficiently large enough to deter deals, ${ }^{123}$ the more significant problem is that managers can employ these arrangements to grant themselves a disproportionate share of the gains from an acquisition-the very gains proponents of shareholder choice seek to wrest from them. ${ }^{124}$ Under shareholder choice, executives facing a greater risk of termination could legitimately insist on larger severance packages. This would enable them to appropriate a larger share of the gains from tender offers. ${ }^{125}$ Moreover, large severance packages would substantially reduce the disciplining effect of a tender offer for management. Cushioned by golden parachutes, managers might feel considerable latitude to

${ }^{122}$ The cost of these payments may be greater than other executive compensation if the cash amount exceeds Internal Revenue Services limitations on cash compensation, resulting in the firm being unable to deduct these amounts. See Nomad Acquisition Corp. v. Damon Corp., Nos. 10173, 10189, 1988 Del. Ch. LEXIS 133, *17-18 (Del. Ch. Sept. 20, 1988) (" $[\mathrm{A}]$ corporation will be denied a tax deduction for a sizable portion of any golden parachute payment where the payment exceeds three times the employee's annual average compensation.").

${ }^{123}$ In theory, managers also could use severance packages to deter acquisitions. While, currently, executive severance packages are not sufficiently large enough to deter deals, there is little reason to believe the structure of such plans would remain fixed following implementation of shareholder choice. Managers could use these packages to raise significantly the cost of a tender offer. Managers also could increase bidders' costs through the grant of executive stock options and Employee Stock Option Plans with long vesting periods containing change of control provisions that accelerate vesting upon change of control. This imposes significant additional costs on acquirers, who must buy out all these additional shares at the bid price. See Brian J. Hall \& Kevin J. Murphy, The Trouble With Stock Options, 17 J. ECON. PERSPECTIVES 49, 50,52 (2003) (explaining that option plans, including ESOPs, often grant stock options to employees and executives with vesting periods that may be as long as four years, but contain change of control provisions that accelerate the vesting of these stock options upon a change of control).

${ }_{124}$ See infra text accompanying notes $134-35$ and Part IV.D (explaining why shareholder choice may reduce shareholders' welfare even if shareholders employ incentive compensation to deter managers from adopting pre-bid embedded defenses).

${ }^{125}$ Courts would likely invalidate compensation that is completely unreasonable. Yet managers subject to shareholder choice would have a strong claim to needing larger golden parachutes to compensate them for the greater risk of a hostile deal. 
pursue private benefits, viewing an acquisition as an opportunity to accelerate their opportunity to reap considerable private gains.

\section{THE INCENTIVE TO EMPLOY EMBEDDED DEFENSES}

The preceding discussion illustrates the wide variety of pre-bid embedded arrangements that could be used to thwart tender offers if other defenses from Table 1 were unavailable. Moreover, should courts regulate the most targeted of these arrangements, managers could simply turn to less targeted means, such as blanket change of control provisions. These unregulable defenses could be far more costly to shareholders than existing pure defenses, as they would deter both friendly and hostile deals. ${ }^{126}$

The possibility of managerial substitution into blanket pre-bid embedded defenses presents a serious challenge to proponents of shareholder choice, because it reveals that regulation of all targeted defenses could make shareholders worse off by inducing substitution into defenses that impose greater costs on the firm. ${ }^{127}$ The degree to which such substitution undermines the case for shareholder choice, however, turns on whether managers actually would resort to untargeted defenses. After all, defenses that deter all acquisitions hurt managers as well as shareholders. Accordingly, our argument turns centrally on whether there exists a credible threat that managers, unable to retain control over hostile acquisitions, would instead employ blanket embedded defenses, notwithstanding any chilling effects on friendly acquisitions. ${ }^{128}$

This Section evaluates whether managers can indeed be expected to employ untargeted embedded defenses at the pre-bid stage if subject to a strong shareholder choice regime. In order to examine this issue, we consider the strongest version of shareholder choice under which courts prevent managers from exerting any post-bid control

${ }^{126}$ See supra Part II.C.2 (discussing why such defenses are unregulable); see also supra Part I.D.1 (discussing unregulability of pre-bid embedded defenses).

${ }^{127}$ To grant shareholders control over tender offers, courts would need to regulate all targeted defenses, and not just some of them such as those imposed post-bid, because otherwise managers could simply employ alternative, unregulated, targeted defenses (such as "hostile trigger" penalty change of control debt covenants) to retain control over tender offers. See infra Part V.A (discussing the problems with intermediate shareholder choice regimes). Whether regulating all targeted defenses promotes shareholder welfare, however, turns on whether managers would respond by adopting unregulable blanket embedded defenses.

${ }^{128}$ See Gilson, supra note 22, at 887-90 (arguing that managers will not adopt blanket pre-bid defenses because these defenses are too costly to managers). 
over tender offers by prohibiting the use of pure, post-bid, and targeted pre-bid embedded defenses. In other words, we consider a regime under which managers are limited to blanket defenses (in the fourth quadrant of Table 1)-specifically, pre-bid blanket embedded defenses-that operate prior to any bid, by deterring acquisitions generally. ${ }^{129}$ Within this setting we examine whether managers would be willing to adopt these defenses, even at the obvious cost to themselves of decreasing the probability of a friendly deal. ${ }^{130}$ Relatedly, we examine whether managers would be willing to employ such nontargeted defenses even at the cost of reducing value from the shareholders' perspective. ${ }^{191}$

\section{A. The Costs and Benefits to Managers of Blanket Defenses}

Perhaps the best way to understand the credibility issue is to compare managers' incentives under a shareholder choice regime (as defined above) with those under a managerial choice regime that permits managers either to preclude all unwanted hostile bids or to steer acquisitions toward friendly deals that compensate managers for

${ }^{1 * 9}$ This version of shareholder choice is the most important to analyze because, under a weaker shareholder choice regime that permits some targeted defenses (which systematically deter only hostile bids), managers would surely opt to employ those defenses, thereby rendering the legal regime ineffectual at little additional cost to the firm or the manager. Yet, the wisdom of attempting to regulate all post-bid and targeted defenses depends on whether this would induce managers to employ blanket defenses.

${ }^{130}$ This version of shareholder choice is consistent with the proposal of Lucian Bebchuk, who argues in favor of requiring boards to submit all tender offers to shareholders for a vote and forbidding boards from implementing any post-bid defensive measures without shareholder approval. See Bebchuk, supra note 9, at 975-76 (arguing against board veto power and for undistorted shareholder choice). We analyze a regime that surpasses his proposal by excluding all targeted defenses because existing shareholder choice proposals lose much of their normative punch if managers could easily retain control through targeted pre-bid embedded defenses. See supra Part II.B (discussing substitute targeted defenses); infra Part V.A (discussing intermediate shareholder choice regimes).

Nevertheless, while we presume provisionally that courts could prohibit all targeted pre-bid embedded defenses, we expect that courts in fact would be unable to preclude managers from retaining control over tender offers post-bid, for the reasons given in Part II.B. In this instance, a shareholder choice regime would do little more than replace one type of targeted defense with another, with no resulting increase in shareholder control over tender offers.

131 Many of these pre-bid embedded defenses may themselves be value enhancing. Thus, the critical issue for evaluating managerial responses to shareholder choice is not to ask whether managers would ever adopt pre-bid embedded defenses (since many would anyway), but rather whether managers might do so in instances where they make shareholders worse off. 
private benefits. The credibility of the threat that a manager may implement value-reducing blanket embedded defenses depends on whether expected gain to managers of employing such a defense exceeds the expected costs, given the alternative defenses available to managers and the expected costs (or benefits) to managers of acquisitions. Managers benefit from the use of blanket defenses to the extent that these defenses protect managers' private benefits by deterring hostile acquisitions that managers could not otherwise deter through alternative, more targeted, defenses. ${ }^{132}$

Yet blanket embedded defenses also impose potential costs on managers. First, some blanket defenses reduce firm value for reasons other than their effect on acquisitions. This hurts managers to the extent that their welfare depends on the firm's profits. Second, and generally more significantly, blanket defenses may reduce managerial welfare by deterring friendly deals as well as hostile ones. ${ }^{133}$ Managers are loath to deter friendly deals to the extent they expect to receive them because acquirers often grant managers private benefits in the course of these transactions. In addition, managers benefit from such acquisitions in their capacity as shareholders.

Accordingly, managers' incentives to employ blanket defenses depends on whether the benefit they reap by using blanket defenses to deter hostile deals outweighs the cost they incur by deterring friendly ones. As shall be shown, this depends on the nature of the legal regime governing shareholder choice. It also depends, of course, on the extent to which shareholders respond to the threat by altering the manager's compensation package.

\section{B. Managers' Incentives Under Managerial Choice}

Under a managerial choice rule, managers have no reason to adopt value-reducing blanket defenses that deter hostile and friendly deals alike because they can employ targeted defenses both to deter hostile deals and to channel would-be acquirers toward managerfriendly acquisitions. As such friendly overtures typically compensate managers for their foregone private benefit of control, managers

192 The benefit to managers of deterring hostile deals depends on the magnitude of managers' private benefits (net of any foregone gains managers would obtain from selling their shares in a hostile acquisition). It also depends on the probability that managers could deter the hostile acquisition through other, more targeted, means.

${ }^{133}$ We define a hostile acquisition as one that does not grant managers substantial private benefits. 
protected by a managerial veto rule have a strict preference for allowing as many friendly offers as possible. Consequently, if given a choice between a broad defense that would deter all forms of acquisition and a targeted defense that would deter only hostile bids, managers would strongly prefer the latter. Thus, all else held constant, they would eschew blanket defenses.

\section{Managers'Incentives Under Shareholder Choice}

A strong shareholder choice regime would fundamentally alter managers' incentives to employ blanket defenses, increasing the strategic benefit of such measures while simultaneously reducing their cost. Under such a regime, managers would be much more willing to adopt blanket pre-bid defenses, even if these blanket defense approaches were inefficient for the firm. ${ }^{134}$

Under an effective shareholder choice regime that precludes all targeted defenses, managers would obtain considerable benefit from blanket defenses because these defenses would be managers' only way to deter hostile acquisitions that threaten managers' private benefit of control. As shareholder choice also increases the relative attractiveness of hostile offers for undefended firms, the benefit to managers of employing an embedded defense grows accordingly.

Shareholder choice not only would increase the benefit managers reap from blanket defenses, it also would reduce the cost they incur from reducing friendly deals. While managers are loathe to deter friendly deals that confer substantial private benefits, managers would not expect to receive such offers under an effective shareholder choice regime. Indeed, because such a regime grants shareholders control over the fate of competing offers, acquirers would compete to curry the favor of shareholders alone, not the board. Consequently, acquirers would pay all the gains to shareholders instead of conferring substantial private benefits on management. Thus, from management's perspective, most proposed acquisitions would operate like hostile offers, in that they would not ensure managers obtain compensation for their private benefits.

Accordingly, shareholder choice would weaken the central existing impediment to managers' use of blanket defenses: their desire to obtain private benefits through potential friendly acquisitions. With much to gain from deterring hostile deals and little to lose from

194 The next Part presents a formal analysis of managers' incentives under shareholder choice. See infra Part IV. 
deterring friendly acquisitions, managers would have a significantly greater incentive to employ value-reducing blanket defenses. Moreover, managers' incentives to deter hostile acquisitions would be greater than at present because, absent defenses, the risk of a hostile bid would be substantially increased by the adoption of shareholder choice.

Accordingly, once managers' up-front incentives are accounted for, informed shareholder choice need not enhance shareholder welfare. While shareholder choice would increase the probability that any tender offer that is made succeeds, it may reduce shareholder welfare by (1) reducing the total number of acquisitions attempted, and/or (2) the amount that acquirers would be willing to pay even in successful acquisitions.

Contributing to this problem is the fact that shareholders would find it difficult to avoid the negative repercussions of shareholder choice by simply increasing managers' incentive pay in order to deter them from selecting embedded defenses. Shareholders potentially could try to deter managers from adopting blanket defenses by granting managers a sufficient stake in the firm that they benefit from hostile bids. Yet this would not enable shareholders to avoid the cost of the substitution effect because to deter untargeted defenses, shareholders may need to grant managers such a large stake in the firm that shareholders gain less from the firm than they would under managerial choice. ${ }^{135}$ Thus, far from eliminating the "substitution cost" of shareholder choice, incentive compensation would just alter when and how shareholders bear it, potentially resulting in lower shareholder welfare than is available under managerial choice. ${ }^{196}$

${ }^{133}$ See infra Part IV.D (demonstrating the conditions where this occurs). Shareholders also would appear to have other means of regulating managers, for example, the proxy contest. Yet proxy contests may not be an effective mechanism for deterring the use of blanket embedded defenses because shareholders of firms with such defenses may gain little from replacing existing management. Supra note 67 . Consistent with this, there is little evidence that non-acquirer shareholders' attempt to regulate managers' use of existing defenses by mounting proxy contests, outside of proxy contests associated with takeovers. Shareholders would be particularly unlikely to use the proxy contest to punish managers for adopting pre-bid embedded blanket defenses because shareholders generally cannot determine whether the defense was value reducing when adopted. and they cannot remove the defense by changing the composition of the board. See supra notes 67,118 (discussing the limitations of proxy contests).

${ }^{136}$ Our analysis compares a strong shareholder choice regime to a managerial choice regime that permits managers to "just say no" to unwanted hostile acquisitions. This managerial choice regime is similar to that prevailing under existing Delaware law. We find that this form of managerial choice regime may be superior to a strong 


\section{FORMAL ANALYSIS}

The preceding sections of this Article have concentrated on the institutional setting that frames our central argument, and the underlying intuition of that argument. In this Part, we demonstrate more formally our claim that a shareholder choice regime may induce managers to implement pre-bid blanket embedded defenses that impose greater costs on the firm than targeted defenses by deterring both hostile and friendly deals. To focus our inquiry, we will analyze a stylized, theoretical model of firm management in a takeover setting. As with any model, our analysis presents a simplified portrait of the world, but one that reflects certain core characteristics of the acquisitions context that are critical for evaluating competing legal regimes.

Specifically, the analytical framework we explore below captures at least five characteristics of the takeover market that-given our discussion above-appear to be the most salient. First, we presume that managers of corporations are motivated principally by self interest. In particular, managers derive private benefits from their positions of control, which in turn provide them with a strong incentive either to preserve their positions (in the case of a hostile bid) or to demand compensation from an acquirer (in the case of a friendly bid).

Second, we presume that an active market for corporate control exists, so that some component of firm value comes from the prospect of a future takeover (hostile or friendly). Indeed, as we demonstrate below, the legal treatment of shareholder choice only "matters" when such a market exists.

Third, we presume that shareholders are sufficiently sophisticated and coordinated to evaluate business decisions (such as whether to

shareholder choice regime that precludes managers from exerting authority over which tender offers succeed.

Our conclusion that this form of managerial choice may be superior to a strong shareholder choice regime does not imply, however, that shareholder welfare would be higher under an even stronger managerial choice regime. Indeed, we expect quite the contrary: granting managers additional protections beyond the ability to employ pure defenses could be welfare reducing. Accordingly, the results of our analysis are not inconsistent with empirical evidence that, all else equal, Delaware firms are more valuable than are firms incorporated in states with even stronger antitakeover laws than Delaware. See Robert Daines, Does Delaware Law Improve Firm Value?, 62 J. FIN. ECON. $525,546-47$ (2001) (finding that firms incorporated in states with severe antitakeover statutes have lower value than those incorporated in Delaware).

In a subsequent part we suggest that a hybrid regime that forces managers to submit some (but not all) deals to shareholders for approval may be superior to both a strong shareholder choice regime and Delaware's manager choice regime. Infra Part V.B. 
sell their shares) when a bid emerges. This assumption reflects our endeavor to interpret shareholder choice proposals in the light most favorable to their proponents. If shareholders were not sophisticated in this way, or suffered significant collective action problems, it would constitute an independent argument against shareholder choice.

Fourth, we suppose that neither shareholders nor courts are sufficiently informed to evaluate decisions made in the ordinary course of business, and thus cannot assess whether a given pre-bid defense increases or reduces value. This assumption is also consistent with the shareholder choice literature, which largely concedes the existence of an unregulable arena of ordinary business activities outside the practical oversight of shareholders.

Finally, and critically, we suppose that managers subject to a strong shareholder choice regime can implement pre-bid embedded defenses that deter bids by reducing the value of the firm in the event of an acquisition (such as blanket penalty change of control provisions). Such defenses, moreover, need not be in the overall interests of shareholders of the company.

With these five institutionally informed assumptions in mind, we now proceed to a description of the framework for our analysis.

\section{A. Framework}

Consider a business enterprise (or firm) that exists for two periods and is-at least initially-owned by a homogenous group of shareholders. We assume (as noted above) that the firm's shareholders do not suffer from collective action problems that would disable them from acting in a coordinated fashion and, thus, can be treated as a homogenous entity. ${ }^{137}$

We further suppose that the ex post value of the firm has an element of risk, which is realized only at the end of the second period. Explicitly, the value of the firm could be either "high" (and equal to $V_{H}$ ) or "low" (and equal to $V_{L}<V_{H}$ ), with probabilities and values specified below. The expected value of the firm will generally depend on both the quality of management and the choices managers make while controlling the firm.

The shareholders of the firm are unable to manage the firm themselves, and they therefore hire a liquidity constrained, risk

${ }^{197}$ This assumption enables us to examine shareholder choice in the light most favorable to its success. If shareholders were subject to large collective action problems, it would constitute an independent argument in favor of managerial control. 
neutral manager (denoted by $M$ ) to manage the firm. The manager has an objective underlying quality, which we denote as $q$, and equate with the probability that the firm realizes a high value rather than a low value. This quality characteristic is distributed uniformly between 0 and 1 . While not known initially, its true value is realized and observed by both the shareholders and managers just prior to a bid being made. ${ }^{138}$ At this juncture, then, both shareholders and the incumbent manager will know that the firm's expected gross payoff is equal to $q V_{H}+(1-q) V_{L}$.

In managing the firm, $M$ is in a position to make an important investment decision on behalf of the company. In particular, she must decide between pursuing one of two projects. Project 1 (Pl) represents the "status quo"; an activity that does not materially change the existing profile of the company. Should the firm pursue this project, we normalize the firm's realized value to be either $V_{H}=1$ or $V_{L}=0$. Project 2 ( P2), in contrast, represents a pre-bid blanket defense embedded into the firm's other activities. P2 has two effects on the firm, altering both the firm's expected value under current management and the probability or terms of a tender offer. ${ }^{139}$

First, $\mathrm{P} 2$ affects the firm's expected value by altering the value of $V_{H}$. In particular, under $\mathrm{P} 2$ the firm's ex post value is either $V_{H}=\Delta$ or $V_{L}=0$. Relative to the status quo, $\mathrm{P} 2$ can potentially be either value increasing or decreasing: thus, $\Delta$ may be any nonnegative number, and in particular, $\Delta$ could be greater than or less than one. The expected value of the firm under current management is therefore equal to $q$ when the firm pursues $\mathrm{P} 1$ and equal to $\Delta q$ when the firm pursues $\mathrm{P} 2$. As a benchmark, note that if the possibility of a takeover

${ }^{138}$ It is possible to alter this assumption and suppose that shareholders never discover the manager's quality. But once again, such an assumption would stack the deck against a shareholder choice regime, as the manager would have strictly better information about the merits of an outside tender offer. In addition, it would be possible to alter the model to allow the manager to know her quality ex ante and have the shareholders learn it later. In the interest of simplification (and to avoid analysis of a number of signaling considerations that are not germane to our inquiry), we have opted for a simpler framework. The same qualitative intuitions would remain in a more complicated model.

${ }^{199}$ Note that we have restricted our attention to a choice between two managerial strategies: the status quo (with, as will become apparent, a targeted defense) and a pre-bid embedded defense. This clearly simplifies the $2 \times 2$ matrix offered in Table 1 , but it does so without any loss of generality, as a similar analysis applies to each of the sub-choices within Table 1. 
is ignored, the firm's value is maximized when $M$ chooses $\mathrm{P} 2$ whenever $\Delta \geq 1$ and $\mathrm{P} 1$ otherwise. ${ }^{140}$

Second, $\mathrm{P} 2$ affects the firm by altering firm value in the event of a takeover. In particular, if $\mathrm{M}$ selects $\mathrm{P} 1$, the status quo, an acquisition does not itself alter firm value: thus, an acquirer who purchases a controlling interest in the firm is essentially in the same position as the manager she displaces. By contrast, under $\mathrm{P} 2$, an acquisition does alter firm value-for example, by triggering a change of control penalty. Explicitly, a successful acquirer (friendly or hostile) obtains merely a fraction $c$ of the firm's value upon the successful acquisition (where $c<1$ ). The $(1-c)$ fraction of the firm's value that the acquirer does not receive represents an extra cost of the acquisition.

In practical terms, $\mathrm{P} 2$ could represent any of a variety of actions that managers can take to drive a wedge between their own costs of managing the firm and those of an outsider. These include the various blanket embedded defenses discussed in the previous Parts that potentially reduce firm value both before and after an acquisition, including preferred stock with change of control penalty puts, thirdparty contracts with change of control provisions, managerial contracts with severance clauses, strategic spin-offs, idiosyncratic organizational structures, and the like. As noted above, some of these actions might be perfectly justifiable from an organizational perspective in that they confer sufficiently large benefits to justify their costs (i.e., $\Delta$ is large relative to $c$ ); others, however, have little value and impose net costs on the firm. Significantly, although the manager can determine whether $\mathrm{P} 2$ is value enhancing in the ex ante period where project selection occurs, neither shareholders nor courts can effectively regulate the manager's project choice (or otherwise regulate the choice of P2). ${ }^{141}$

In addition to determining the firm's operational profile, we assume that the manager enjoys private benefits from controlling the firm-a perquisite that comes at the expense of shareholders. Explicitly, we suppose that $M$ can divert a fraction of the firm's value, denoted by $\beta$, for her personal gain. This diversion is wasteful, however, in that the manager actually receives only a $\left(\beta-\frac{1}{2} \beta^{2}\right)$ share of what she appropriates, which is less than the value of harm visited on

${ }^{140}$ Interestingly, as will become clear below, it might also be inefficient to choose P2 even when $\Delta>1$ since the adoption of P2 would also deter some future takeovers.

${ }^{141}$ In technical terms, then, we assume that project choice is not contractable. See infra notes 148-56 and accompanying text (elaborating on the strategies and constraints on a potential acquirer after $\mathbf{M}$ has made a project choice). 
the shareholders. ${ }^{142}$ Nonmanagerial shareholders can attempt to provide managers with the incentives not to reduce firm value in this way, however. Indeed, without such incentives, $M$ chooses to divert the entire value of the firm. ${ }^{149}$

Accordingly, nonmanagerial shareholders compensate $M$ with a contract that potentially has both a fixed wage component and an incentive compensation component. We denote the fixed salary component by $w$. Shareholders also offer M incentive pay, by granting her a fractional ownership share in the company, denoted by $\sigma$, which represents restricted stock, stock options, and so forth. Consequently, once this incentive compensation is paid, the nonmanagerial shareholders retain only a $(1-\sigma)$ share of the firm's net value.

To simplify things, we normalize the best payoff that the manager could get working outside the company to be zero, and assume that the manager has no existing wealth. This means that the values of $w$ and $\sigma$ can never be negative (this accords with what we observe in reality).

Finally, in order to compare the takeover effects of a shareholder choice regime against a managerial choice regime, we introduce a market for corporate control. In later subsections we also allow a

${ }^{142}$ This assumption captures the idea that private benefits may be more than just a transfer payment-imposing no efficiency losses-but in fact may be value reducing. This expression can be generalized in many ways without loss of generality. For example, a similar setup appears in LUCIAN ARYE BEBCHUK, ASYMMETRIC INFORMATION AND THE CHOICE OF CORPORATE GOVERNANCE ARRANGEMENTS 8-10 (John M. Olin Center for Law, Econ., and Bus., Discussion Paper No. 398, 2002), http://www.law. harvard.edu/programs/olin_center/papers.htm, where the manager's private benefits are given by $\beta-\frac{1}{2 \gamma} \beta^{2}$. The parameter $\gamma$ captures the efficiency with which $\mathrm{M}$ can siphon off value; when $\gamma$ is relatively large, $M$ is an efficient appropriator of value. Conversely, when $\gamma$ is relatively small, $M$ does not especially benefit from appropriating value (either because she is not terribly good at it, or because she feels remorse at doing so, and so forth). Nevertheless, note that the marginal benefit to the manager of value appropriation is $1-\frac{\beta}{\gamma} \leq 1$. M is presumed to set $\beta$ after the project type is selected and any control transactions are decided, but before final realization of the project's value. We have chosen a simpler equation to represent the manager's private benefits in order to focus on other conceptual details.

${ }_{143}$ To see this, note that the marginal value of taking private benefits is equal to $(1-\beta)$. This is positive for all $\beta<1$, and thus without any countervailing incentive, $M$ will appropriate the whole value of the firm.

The conclusion that managers will divert the entire value of the firm unless granted incentive compensation (i.e., stock) flows from the fact that we have not formally incorporated any constraints imposed by shareholders' ability to elect new managers. Introducing proxy contests would reduce managers' ability to misappropriate firm value, but would not affect our ultimate conclusions that shareholder choice increases managers' incentives to employ value-reducing defenses to deter acquisitions. 
third party, denoted by $B$, to make a bid for the entire corporation. ${ }^{144}$ The way in which the firm responds to $B$ 's offer turns on the underlying legal regime, which is the critical point of inquiry in this Article. Under a "managerial choice" regime, $M$ exercises control over which bids make it to shareholders, and thus, B 's bid must be acceptable to both managers and shareholders. Under a "shareholder choice" regime, in contrast, $M$ does not exercise such control, and thus, $B$ 's bid need only be acceptable to shareholders. We shall elaborate more on B 's characteristics and strategies as they become relevant. ${ }^{145}$ Summarizing, then, the sequence of the game is as follows:

Figure 1. Sequence of Decisions

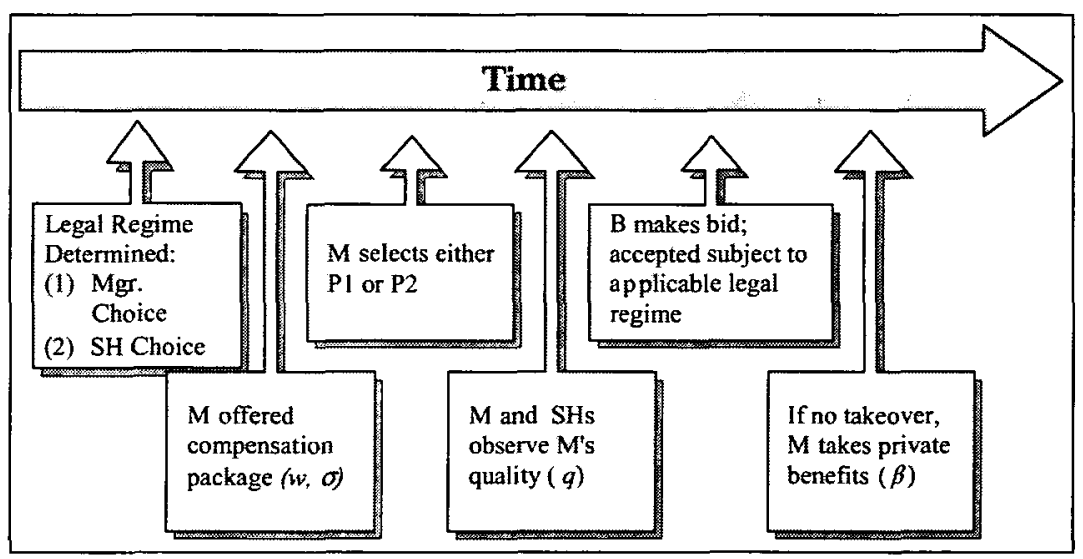

\section{B. No Market for Corporate Control}

As a baseline for later comparisons, it is useful to begin by considering a special case in which no takeover market exists. In the absence of a takeover market, P1 and P2 differ only through their effect on $V_{H}$, since no acquirer will ever confront the additional costs imposed by $\mathrm{P} 2$. As such, P1 can be thought of as a special case of $\mathrm{P} 2$, in which $\Delta=1$; we shall therefore concentrate on the more general case of $\mathrm{P} 2$ in what follows.

First, consider the parties' respective payoffs. Given the manager's underlying quality level, $q$, and level of benefit extraction, $\beta$, the aggregate value of the firm (or $\pi_{F}(q, \beta)$ ) consists of the expected

${ }^{144}$ See infra notes 148-55 and accompanying text (assessing how the introduction of a potential acquirer affects the market for corporate control).

${ }^{145}$ Id. 
value of the project less the fixed component of the wage paid to $M$ :

$$
\pi_{F}(q, \beta)=\underbrace{(1-\beta)}_{\text {Exp.Val.of Project }} \cdot \Delta q-\underbrace{w}_{\text {Fixed Wage }}
$$

This value generally corresponds to the total capitalized stock value of the company. Of this value, nonmanagerial shareholders enjoy a $(1-\sigma)$ share, while $M$ receives the remaining $\sigma$ share. But in addition to her pro rata ownership share, $M$ receives both her private control benefits and her flat wage. Thus, the expected payoff of $M$ is as follows:

$$
\begin{gathered}
\pi_{M}(q, \beta)=\underbrace{\sigma \cdot((1-\beta) \cdot \Delta q-w)}_{\text {Share ownership component }}+\underbrace{\left(\beta-\frac{1}{2} \beta^{2}\right)}_{\begin{array}{c}
\text { Private Ben. } \\
\text { Component }
\end{array}} \cdot \Delta q+\underbrace{w}_{\text {Wage }} \\
=\left(\sigma \cdot(1-\beta)+\beta-\frac{1}{2} \beta^{2}\right) \cdot \Delta q+(1-\sigma) \cdot w
\end{gathered}
$$

The manager sets $\beta$ to maximize her expected payoff, which yields an optimal level of value diversion of $\beta^{*}=(1-\sigma)$. Note that this optimal choice is independent of either the expected value of the project chosen $(\Delta q)$ or the manager's fixed wage $(w)$. Substituting this value into the parties' various payoffs, it is possible to derive Table 2 below. The columns of Table 2 correspond to the project chosen by the manager (i.e., P1 or P2). The rows of the Table correspond to different slices of the total payoff created from the selected project. The first row reflects the manager's expected payoff (which includes her private benefits, wages, and her pro rata earnings as a shareholder). The second row reflects the expected payoff of nonmanagerial shareholders. The third row reflects the total capitalized value of the company (that is, the sum of all the parties' share values). The fourth row reflects the sum of the managerial and nonmanagerial expected payoffs, which we refer to as "aggregate" value. 


\section{Table 2}

Expected payoff under P1 Expected payoff under P2

\begin{tabular}{l|c|c|}
\cline { 2 - 3 } Manager & $\left(\frac{1+\sigma^{2}}{2}\right) q+(1-\sigma) w$ & $\left(\frac{1+\sigma^{2}}{2}\right) \Delta q+(1-\sigma) w$ \\
\cline { 2 - 3 } Non-M SHs & $(1-\sigma) \sigma q-(1-\sigma) w$ & $(1-\sigma) \sigma \cdot \Delta q-(1-\sigma) w$ \\
\cline { 2 - 3 } Firm Value & $\sigma q-w$ & $\sigma \Delta q-w$ \\
\cline { 2 - 3 } $\begin{array}{l}\text { Aggregate } \\
\text { Value }\end{array}$ & $\left(\sigma+\frac{1-\sigma^{2}}{2}\right) q$ & $\left(\sigma+\frac{1-\sigma^{2}}{2}\right) \Delta q$ \\
\cline { 2 - 3 }
\end{tabular}

In the discussion below, we use the term $\mu_{0}$ as a shorthand for the term $\sigma+\frac{1-\sigma^{2}}{2}$. (For future reference, note that $\mu_{0} \geq \sigma$ and that $\mu_{0} \geq \frac{1}{2}$.)

The optimal compensation package for $\mathrm{M}$ is one that attempts to maximize the nonmanagerial shareholders' payoff subject to the constraints that (1) the manager must be paid enough to be willing to work for the firm; and (2) the shareholders cannot directly control which project the manager selects, but can only use the compensation package to provide incentives to $M$. $^{146}$

Analysis of this problem yields the conclusion that, in the absence of a market for corporate control, the optimal contract pays $M$ a wage of $w^{N}=0$, and offers $M$ incentive compensation of $\sigma^{N}=\frac{1}{2}$. Under this contract, the manager sets $\beta^{N}=\frac{1}{2}$, and chooses the project $P 1$ if and only if $\Delta<1$.

A few details bear note about this result. First, even in this baseline case, the optimal compensation package consists of a minimal feasible wage level (which by our normalization implies $w^{N}=0$ ), ${ }^{147}$ and then uses ownership shares in the company to provide incentives for the manager to refrain from taking too many private benefits. In particular, in this simple baseline case the optimal contract pays $M$ fully half of the firm's ownership shares in order to provide appropriate deterrent incentives. This level of compensation may seem unrealistically high on first blush, and it would likely be smaller if we allowed for other possible constraints on managerial behavior (such as proxy contests) in a richer model. Adding such constraints, however, would

${ }^{146}$ These constraints are often referred to, respectively, as "participation" and "incentive" constraints.

${ }^{147}$ This will turn out to be true for the remainder of the discussion, and thus without any loss of generality, we suppress the analysis of a flat wage and simply impose the condition $w=0$. 
only introduce complexity without offering our fundamental conclusions about shareholder choice. ${ }^{148}$

Second, and perhaps most importantly, this baseline case reveals that, in the absence of takeovers, shareholders can perfectly align the manager's incentives with their own insofar as project choice is concerned. Indeed, the manager always chooses the highest value project from the shareholders' perspective and never selects project P2 when it is inefficient (from the nonmanagerial shareholders' perspective) to do so. Indeed, without any takeover market to worry about, the manager evaluates $\mathrm{P} 2$ solely based on its ability to increase the firm's value (to which she has a fractional claim).

\section{Market for Corporate Control}

Now consider $M$ 's incentives when faced with the possibility of a takeover. As noted above, we assume that after $M$ makes a project choice, a single bidder (denoted by $\mathrm{B}$ ) emerges as a potential acquirer. Similar to $\mathrm{M}, \mathrm{B}$ has some ability to run the firm, and thus possesses her own quality parameter, $\theta$, which we assume is similarly distributed uniformly between 0 and 1 (but is statistically independent of $M$ 's quality). Consequently, the bidder might be better than the incumbent, but she is not necessarily so. The buyer must decide on her bid without knowing the manager's quality-although the buyer does know the distribution of $q$. She bids on control of the entire firm based on her conjectures about incumbent managerial quality. ${ }^{149}$

This Section analyzes and then compares two alternative rules for regulating takeovers. Under the first rule (which we call "managerial choice"), $\mathrm{M}$ has the right to veto a tender offer before other shareholders are allowed to vote on it. This rule effectively requires that a

${ }^{148}$ Even small modifications to our framework could reduce this value. For instance, if $M$ 's private benefits were equal to $\left(\beta-\frac{1}{2 \gamma} \beta^{2}\right)$ the optimal incentive scheme would pay $\mathrm{M}$ a share component of $\sigma-\max \left\{0,1-\frac{1}{2 y}\right\}$. Thus, for small values of $\gamma$, the manager receives very little incentive compensation because she is not sufficiently talented at diverting value. We resist adding additional parameters like this to the model since they would add little more than additional notational complexity. Moreover, as we shall see below, infra notes 148-56 and accompanying text, the introduction of a market for corporate control will tend to reduce the optimal share compensation below this level.

${ }^{149}$ Note that since $\mathrm{M}$ has chosen the project prior to the realization of $q$, the observed project choice signals nothing to the bidder about the manager's quality. In addition, we assume in what follows that a takeover by the bidder is tantamount to a purchase of all the company's shares (rather than, say, a bare voting majority). Nothing turns on this assumption. 
takeover offer be a friendly offer that compensates both the manager and the shareholders for their respective reservation values. Such a rule would correspond to permitting managers to "just say no." Under the second rule (which we call "shareholder choice"), shareholders alone have the right to approve or disapprove a tender offer. This rule, therefore, effectively allows either friendly or hostile bids (though in our framework all such bids will appear hostile). In order to give the shareholder choice rule a fair hearing, we shall assume (as noted above) that the shareholders make an informed choice about whether to sell, and thus learn about the incumbent manager's quality before voting on a tender offer under either rule.

\section{Managerial Choice Regime}

First, consider the impact of the takeover market on firm valueand in particular on the manager's choice between P1 and P2 under a managerial choice regime. Under such a rule, both $\mathrm{M}$ and the nonmanagerial shareholders must approve a tender offer in order for $B$ to succeed in acquiring the firm. Thus, the acquirer's bid must attempt to compensate both the manager and the shareholders to gain their joint approval. Consequently, under a managerial choice rule, all tender offers must, by definition, be friendly ones. In this case B will offer two prices when making her bid: one for the purchase of all outstanding shares (denoted as $p_{S}$ ) and the other functioning as an additional "side payment" that goes to the incumbent manager to obtain her approval (denoted as $\left.p_{M}\right)$. $^{150}$

For B 's tender offer to be successful, it must meet or exceed both the incumbent shareholders' and $M$ 's expected payoffs under the status quo. In particular, the manager will approve the acquisition if she reaps gains from the deal at least as large as those she would have received from continuing with the firm. Similarly, shareholders must be as well off under the acquisition as they would be otherwise or they will not approve the deal. Consequently, necessary and sufficient conditions for a successful bid are such that:

- The total bid, $\left(p_{S}+p_{M}\right)$, must equal or exceed the total aggregate value under the chosen project (i.e., the sum of the shareholders' and M's combined expected payoffs), or $\mu_{0} \cdot \Delta q$ from Table 2 .

${ }^{150}$ The amount paid to managers could take the form of a lucrative postacquisition employment contract. Note that by virtue of her share ownership, $M$ also stands to gain a $\sigma$-fraction of the price paid to shareholders. 
- Of this total bid, the fraction directed to shareholders as a group, $p_{S} /\left(p_{S}+p_{M}\right)$, must be set equal to $\sigma / \mu_{0}$, which represents the ratio of firm value to aggregate value under the chosen project. ${ }^{151}$

As previously noted, the total value of project $\mathrm{P} 2$ is $q \Delta$ if managed by incumbent manager $M$. Should $B$ acquire the firm, however, the expected value of the project is $\theta \Delta c \leq \theta \Delta$ (since, by assumption, $c \leq 1$ ). As above, we can limit our analysis to the case of $\mathrm{P} 2$, since $\mathrm{P} 1$ is simply a special case of $\mathrm{P} 2$ where $\Delta=c=1$.

The bidder will set its bid, $b$, so as to maximize expected profits, given by the probability that the bidder offers a bid sufficiently high to induce the manager and shareholders to accept the bid, multiplied by the expected returns to the bidder of the acquisition: ${ }^{152}$

$$
\pi_{B}(b ; \theta)=\min \left\{\frac{b}{\mu_{0} \Delta}, 1\right\} \cdot(\theta \Delta c-b)
$$

Analysis of this problem implies that the profit-maximizing bid ${ }^{153}$ for the bidder is $b^{*}=\frac{\theta \Delta c}{2}$. In other words, the bidder will offer an amount equal to half the expected value of the firm under the bidder's management.

Now consider the probability that a takeover occurs when B follows this bidding strategy. The prospects of a takeover clearly depend on the value $q$, the incumbent manager's quality. The greater the incumbent's quality, the lower the likelihood that the bidder will be able to increase the value of the firm beyond that of current

151 To see this, note from Table 2 that the ratio of firm value to total social value is precisely equal to $\frac{\sigma}{A}$. If price ratio offered by the bidder were not set at this level, the bidder could induce a larger acceptance rate at no additional cost by setting the price ratio accordingly.

${ }^{152}$ To see this, note that:

$$
\begin{gathered}
\pi_{B}(b ; \theta)=\operatorname{Pr}\left\{b \geq \mu_{0} \cdot q \cdot \Delta\right\} \cdot(\theta \Delta c-b) \\
=\operatorname{Pr}\left\{q \leq \frac{b}{\mu_{0} \Delta}\right\} \cdot(\theta \Delta c-b) \\
=\min \left\{\frac{\beta}{\mu_{0} \Delta}, 1\right\} \cdot(\theta \Delta c-b)
\end{gathered}
$$

${ }^{153}$ Explicitly, the first order conditions yield the following:

$$
b^{*}=\left\{\begin{array}{lc}
\frac{\theta \Delta c}{2} & \text { if } \quad \theta \leq \frac{2 \mu_{0}}{c} \\
\mu_{0} \Delta & \text { otherwise }
\end{array} .\right.
$$

But because $\mu_{0} \geq \frac{1}{2}>\frac{c}{2}$, we know that $\theta \leq 1 \leq \frac{2 \mu_{0}}{c}$, and thus the optimal bid is always interior, and is that given above. 
management and, thus, the lower the likelihood that the bidder will be able to make a successful bid. By contrast, the lower the quality of the incumbent manager, the greater the probability that the bidder will be able to find a bid that will induce the manager and shareholders to accept the deal. Mathematically, the probability of a takeover given $q$ is:

$$
\operatorname{Pr}\{\text { Takeover } \mid q\}=\max \left\{\left(1-\frac{2 \mu_{0}}{c} q\right), 0\right\}
$$

A couple of points are worth brief mention at this juncture. First, as noted above, if $q$ is sufficiently high, there is no chance that a takeover will occur and, thus, the bidder's cost parameter, $c$, never is at issue. For these situations, at least, it is clear that $M$ 's incentives are relatively better aligned with those of the shareholders. In particular, these managers are effectively in a "no takeover" regime; such a high quality manager would never select a project solely to ensure a lower chance of a takeover. By contrast, a relatively low quality manager ${ }^{154}$ does face a risk of a tender offer, and thus, we must consider whether such a manager might select project P2, even when it destroys value to deter tender offers. ${ }^{155}$ As we shall see below, it turns out that $M$ will not select P2, against other shareholders' wishes, under a managerial choice regime because managerial choice ensures that a tender offer can never make her worse off.

Given the likelihood of a takeover, we are now in a position to characterize the total aggregate payoffs (of $\mathrm{M}$ and the shareholders) that could be expected under a managerial choice rule. Given that shareholders and the manager are each guaranteed to match their status quo payoffs under a managerial choice rule, the expected total payoffs to the shareholders and manager can be decomposed into the status quo value of the firm, plus the expected premium arising from a friendly deal. Taking expectations into account yields the following expected aggregate payoff: ${ }^{156}$

$$
\text { Aggregate Value }=\left(\frac{\mu_{0}}{2}+\frac{c^{2}}{24 \mu_{0}}\right) \Delta .
$$

${ }^{154}$ That is, one for which $q \leq \frac{c}{2 \mu_{0}}$.

${ }^{155}$ Significantly, because the manager selects the project before she knows her own quality, she must weigh the likelihood that she will be a high-quality manager (and will not fear takeovers) against the chance that she will be low quality and will want added protection against acquisitions.

${ }^{156}$ This is derived by noting that the aggregate expected payoff is equal to

$$
E_{q}\left[\mu_{0} q \Delta+E_{\theta}\left[\max \left\{0, \frac{\theta b c}{2}-\mu_{0} q \Delta\right\}\right]\right] .
$$


Of this sum, recall that shareholders as a group receive a $\frac{\sigma}{\mu_{0}}$ portion of the total payoff, while $M$ 's private benefits constitute the remaining $\left(1-\frac{\sigma}{\mu_{0}}\right)$ portion. Dividing these up after accounting for the manager's shareholdings in the firm, the manager's and nonmanagerial shareholders' expected payoffs under each respective project are:

Table 3

\begin{tabular}{|c|c|c|}
\hline & Payoff under P1 & Payoff under P2 \\
\hline Manager & $\left(1-\frac{\sigma}{\mu_{0}}+\frac{\sigma^{2}}{\mu_{0}}\right)\left(\frac{\mu_{0}}{2}+\frac{1}{24 \mu_{0}}\right)$ & $\left(1-\frac{\sigma}{\mu_{0}}+\frac{\sigma^{2}}{\mu_{0}}\right)\left(\frac{\mu_{0}}{2}+\frac{c^{2}}{24 \mu_{0}}\right) \Delta$ \\
\hline Non-M SHs & $\frac{\sigma}{\mu_{0}}(1-\sigma)\left(\frac{\mu_{0}}{2}+\frac{1}{24 \mu_{0}}\right)$ & $\frac{\sigma}{\mu_{0}}(1-\sigma)\left(\frac{\mu_{0}}{2}+\frac{c^{2}}{24 \mu_{0}}\right) \Delta$ \\
\hline Firm Value & $\frac{\sigma}{\mu_{0}}\left(\frac{\mu_{0}}{2}+\frac{1}{24 \mu_{0}}\right)$ & $\frac{\sigma}{\mu_{0}}\left(\frac{\mu_{0}}{2}+\frac{c^{2}}{24 \mu_{0}}\right) \Delta$ \\
\hline $\begin{array}{l}\text { Aggregate } \\
\text { Value }\end{array}$ & $\left(\frac{\mu_{0}}{2}+\frac{1}{24 \mu_{0}}\right)$ & $\left(\frac{\mu_{0}}{2}+\frac{c^{2}}{24 \mu_{0}}\right) \Delta$ \\
\hline
\end{tabular}

Analysis of this table leads to the conclusion that regardless of the terms of the contract, $M$ 's choice of project coincides precisely with that favored by the shareholders. The optimal contract, $\left(\mathrm{w}^{\mathrm{v}}, \sigma^{\mathrm{v}}\right)$, sets $\mathrm{w}^{\mathrm{v}}=0$, and $\sigma^{v}<\frac{1}{2}$.

The intuition behind this result is straightforward, but important. First, when tender offers are governed by a managerial choice regime, managers always select the "right" project for the firm. Thus, allowing managerial veto over tender offers ensures that $M$ 's incentives concerning project choice are exactly aligned with those of the shareholders, regardless of the manager's incentive compensation. Under managerial choice, managers have no reason to destroy firm value in order to deter acquisition because they have the authority to deter any bidder who does not ensure that the manager receives at least her private benefits of control. While this certainly may chill some takeover bids (by making them more expensive), it removes the manager's incentive to choose P2 solely to chill takeover activity because the managerial choice rule perfectly insures managers against such an outcome. As we shall see below, this alignment of incentives does not necessarily occur under a shareholder choice rule. ${ }^{157}$

${ }^{157}$ Because it is technically tedious, we reserve discussion of the precise terms of an optimal contract for this case until the numerical example discussed in a later Part. 
The second part of the above result discusses the qualitative characteristics of the optimal contract for the manager. As before, the optimal fixed wage for the manager is zero. The optimal share compensation, $\sigma^{v}$, on the other hand, is positive, but smaller than it would be in the absence of a market for corporate control. The reason for this is a bit less obvious, but also straightforward: unlike the case where no takeover market exists, in this case shareholders know that at least some probability exists that their payoff will come in the form of a buyout rather than through $M$ 's management. Consequently, shareholders would like to increase the share of any takeover premium that they (as opposed to $\mathrm{M}$ ) receive. By decreasing $\sigma$, and thereby increasing their own share of firm value, nonmanagerial shareholders can claim a larger fraction of the buyout price when it occurs. On the other hand, decreasing $\sigma$ causes $\mathrm{M}$ to behave more wastefully in situations where a takeover does not occur (by taking more private benefits). Hence, shareholders decrease $\sigma$ to the point where the marginal benefit of claiming a larger share of the buyout surplus is offset exactly by the marginal cost of weakening the manager's incentives.

\section{Shareholder Choice Regime}

We now consider an alternative legal regime in which the success of tender offers hinges solely on shareholder approval, with no managerial veto rights. Under a shareholder choice regime, takeover bids require only the approval of the nonmanagerial shareholders, who hold a $(1-\sigma)$ fraction of the firm. ${ }^{158}$ Consequently, managers cannot take any post-bid actions to affect the probability that the shareholders

See infra Part IV.E (discussing a shareholder choice rule). Nor is such a discussion necessary here, since our result applies to all incentive compatible contracts and not just the optimal one.

${ }^{158}$ Note that our focus here is on non-managerial shareholders, and not all shareholders. Of course, under both state acquisitions law (e.g., DEL. CODE ANN. tit. 8, § 251 (2001)) and federal securities law (e.g., Williams Act, 15 U.S.C.S. $§ 78 \mathrm{n}$ (d) (1968)), tender offers are open to all shareholders (managerial or non-managerial). Nevertheless, our focus on non-managerial shareholders is justified for a number of reasons. First, we are interested in considering shareholder choice in those circumstances where the rule matters most: where non-managerial shareholders could approve a hostile transaction but for management's use of defenses. Second, even if $\mathrm{M}$ held a majority of shares, this decision may have some elements of an interested transaction and, thus, it would possibly require the vote of non-managerial shareholders to cleanse it. Finally, if $\mathrm{M}$ owned a majority of shares, she would be unlikely to approve a tender offer that did not also give her side compensation for her own private benefits and, thus, a shareholder choice regime would be no different from a managerial veto regime. 
approve the deal. Under this regime, a successful buyer obviously still needs to get shareholder approval, but does not need to obtain the manager's consent. In effect, then, shareholder choice transforms all takeovers into "hostile" ones, in that the buyer need not accord the manager any special treatment in making a bid since $M$ 's imprimatur is no longer required. Thus $p_{M}$ is equal to zero. (Recall, however, that the manager may still benefit from a takeover to the extent that she owns a $\sigma$ fraction of the firm.) $)^{159}$

As before, we shall consider how such a scenario would play out for P2 (again noting the fact that P1 is a special case of P2 where $c=\Delta=1$ ). Recall that the expected value of the firm's project is $q \Delta$ if managed by $M$ and $\theta \Delta c$ if by the bidder. Once private benefits are accounted for, the total shareholder value of the company under $\mathrm{P} 2$ is $\sigma q \Delta$. Accordingly, under a shareholder choice regime, $\mathrm{B}$ will set its bid, $b$, to maximize expected profits:

$$
\pi_{B}(b ; \theta)=\min \left\{\frac{b}{\sigma \Delta}, 1\right\} \cdot(\theta \Delta c-b) .
$$

Analysis of this problem yields the profit-maximizing bid for $\mathrm{B}$ of $b^{*}=\min \left\{\frac{\theta c}{2} \Delta, \sigma \Delta\right\} .^{160}$ The probability of a takeover, in turn, depends on the relative values of $\sigma$ and $c$. Following the analysis from the previous Section, the probability that a takeover will occur is given by:

$$
\operatorname{Pr}\{\text { Takeover } \mid q\}=\max \left\{\left(1-\frac{2 \sigma}{c} q\right), 0\right\} .
$$

Note that the probability of a takeover is increasing in $c$. Thus, as intuition would suggest, the greater the negative impact of P2 on the gains to a bidder, the lower the probability of a takeover. The probability of a takeover, however, does not depend at all on $\Delta$. Indeed, because this aspect, $\mathrm{P} 2$, is common to both the incumbent manager and to $\mathrm{B}$, it would be fully realized by both bidder and incumbent symmetrically, thereby reducing both shareholders' minimum acceptable bid price and the value of the firm to the bidder. Accordingly, only the costs of $\mathrm{P} 2$ are reflected in the above expression through $c{ }^{161}$

\footnotetext{
${ }^{159}$ See infra Part V (discussing intermediate regimes).

${ }^{160}$ Or equivalently,

$b^{*}=\left\{\begin{array}{l}\theta \cdot \frac{c}{2} \Delta \text { if } \theta \leq \frac{2 \sigma}{c} \\ \sigma \Delta \text { otherwise }\end{array}\right.$.
}

Only if $\sigma \leq \frac{c}{2}$ would B's optimal bid exhibit a kink at $\theta=\frac{2 \sigma}{c}$.

${ }^{161}$ While the bidder would certainly factor the benefits of P2 into her bid, the shareholders of the firm would similarly do so when analyzing $B$ 's bid. Consequently, 
Comparing this probability to its counterpart in the managerial choice section above immediately generates a few important conclusions. First, the choice of $P 2$ over $P 1$ markedly decreases the probability of a takeover under either shareholder choice or managerial choice. Thus, to the extent that shareholder choice increases managers' incentives to adopt $P 2$, it reduces the probability of a bid occurring. Second, for any given compensation package and product choice, whenever there exists a positive probability of a takeover, it is larger under a shareholder choice regime than it is under a managerial choice regime.

Equivalently, so long as we hold constant both manager's compensation scheme and her initial project choice, a shareholder choice regime increases the probability of a serious tender offer. The latter argument constitutes a principal claim for most proponents of shareholder choice. Our analysis confirms that, indeed, assuming there is no effect on managerial decisions that $M$ makes at the firm, shareholder choice allows incumbent shareholders to claim the sole share of the takeover premium, thereby facilitating the incidence of a takeover bid.

Yet, the above analysis also reveals why shareholder choice need not necessarily increase the probability of a serious tender offer: all else is not always held constant. Explicitly, shareholder choice can reduce the probability of a tender offer in those circumstances where the manager selects P2, but would have selected P1 under a managerial choice rule because P1 maximizes overall firm value. In this circumstance, shareholder choice potentially reduces both the probability of a takeover and the takeover value of the company. Consequently, in order to evaluate the impact of shareholder choice, we need to determine whether managers would select P2, even if doing so would not improve firm value (and, thus, they would not select P2 with a managerial veto).

Consequently, consider now the expected value of the firm (or, equivalently, the total share value) under the shareholder choice rule. Suppressing some tedious algebra, the ex ante expected value of the firm under shareholder choice is:

$$
\text { Firm Value }=\left\{\begin{array}{c}
\Delta \sigma\left(1-\frac{2 \sigma}{3 c}\right) \text { if } \sigma \leq \frac{c}{2} \\
\Delta \sigma\left(\frac{1}{2}+\frac{c^{2}}{24 \sigma^{2}}\right) \text { if } \sigma>\frac{c}{2}
\end{array} .\right.
$$

as $\Delta$ grows larger, the increased eagerness of $\mathrm{B}$ is exactly offset by the larger demands of the firm's shareholders. 
Note from the above that firm value is increasing in both $\Delta$ and $c$. This is intuitively sensible, since increases in $\Delta$ mean a higher overall project payoff, while increases in $c$ mean a more viable market for corporate control. Either of these is good news for the firm's shareholders. Nonmanagerial shareholders, therefore, reap a $(1-\sigma)$ fraction of the above payoff. $\mathbf{M}$, on the other hand, enjoys her pro-rata payoff as a shareholder (i.e., a $\sigma$ - share of the sum calculated above), plus her private benefits should no takeover occur. Once again suppressing some algebra, the following tables represent the parties' respective payoffs depending on project choice.

When the contract is such that $\sigma \leq \frac{c}{2}$ :

\section{Table 4}

\begin{tabular}{l|l|l|}
\multicolumn{1}{c}{} & \multicolumn{1}{c}{ Payoff under P1 } & \multicolumn{1}{c}{ Payoff under P2 } \\
\cline { 2 - 3 } Manager & $\sigma^{2}\left(1-\frac{2 \sigma}{3}\right)+\sigma \frac{\left(1-\sigma^{2}\right)}{3}$ & $\left(\sigma^{2}\left(1-\frac{2 \sigma}{3 c}\right)+\sigma \frac{\left(1-\sigma^{2}\right)}{3 c}\right) \Delta$ \\
\cline { 2 - 3 } $\begin{array}{l}\text { Non-M } \\
\text { SHs }\end{array}$ & $\sigma(1-\sigma)\left(1-\frac{2 \sigma}{3}\right)$ & $\sigma(1-\sigma)\left(1-\frac{2 \sigma}{3 c}\right) \Delta$ \\
\cline { 2 - 3 } $\begin{array}{l}\text { Firm } \\
\text { Value } \\
\text { Social } \\
\text { Value }\end{array}$ & $\sigma\left(1-\frac{2 \sigma}{3}\right)$ & $\sigma\left(1-\frac{2 \sigma}{3 c}\right) \Delta$ \\
\cline { 2 - 3 } & $\sigma\left(1-\frac{2 \sigma}{3}+\frac{1-\sigma^{2}}{3}\right)$ & $\sigma\left(1-\frac{2 \sigma}{3 c}+\frac{1-\sigma^{2}}{3 c}\right) \Delta$ \\
\cline { 2 - 3 } & &
\end{tabular}

When the contract is such that $\sigma>\frac{c}{2}$ :

Table 5

\begin{tabular}{l|l|l|}
\multicolumn{1}{c}{ Payoff under P1 } & \multicolumn{1}{c|}{ Payoff under P2 } \\
\cline { 2 - 3 } $\begin{array}{l}\text { Man- } \\
\text { ager }\end{array}$ & $\left(\frac{1}{4}-\frac{1}{48 \sigma^{2}}\right)+\sigma^{2}\left(\frac{1}{4}+\frac{1}{16 \sigma^{2}}\right)$ & $\left(\left(\frac{1}{4}-\frac{c^{2}}{48 \sigma^{2}}\right)+\sigma^{2}\left(\frac{1}{4}+\frac{c^{2}}{16 \sigma^{2}}\right)\right) \Delta$ \\
\cline { 2 - 3 } $\begin{array}{l}\text { Non-M } \\
\text { SHs }\end{array}$ & $\sigma(1-\sigma)\left(\frac{1}{2}+\frac{1}{24 \sigma^{2}}\right)$ & $\sigma(1-\sigma)\left(\frac{1}{2}+\frac{c^{2}}{24 \sigma^{2}}\right) \Delta$ \\
\cline { 2 - 3 } $\begin{array}{l}\text { Firm } \\
\text { Value }\end{array}$ & $\sigma\left(\frac{1}{2}+\frac{1}{24 \sigma^{2}}\right)$ & $\sigma\left(\frac{1}{2}+\frac{c^{2}}{24 \sigma^{2}}\right) \Delta$ \\
\cline { 2 - 3 } $\begin{array}{l}\text { Social } \\
\text { Value }\end{array}$ & $\left(\left(1-\sigma^{2}\right) \cdot\left(\frac{1}{4}-\frac{1}{48 \sigma^{2}}\right)+\sigma\left(\frac{1}{2}+\frac{1}{24 \sigma^{2}}\right)\right)$ & $\left(\left(1-\sigma^{2}\right) \cdot\left(\frac{1}{4}-\frac{c^{2}}{48 \sigma^{2}}\right)+\sigma\left(\frac{1}{2}+\frac{c^{2}}{24 \sigma^{2}}\right)\right) \cdot \Delta$ \\
\cline { 2 - 3 }
\end{tabular}


Comparing $\mathrm{M}$ 's payoff with the nonmanagerial shareholders' payoff in the above tables, one is immediately struck by the fact that, unlike in the managerial choice case, the manager's and the nonmanagerial shareholders' payoffs are no longer strictly proportional to one another. Indeed, because a shareholder choice regime gives shareholders a unique advantage over $M$ when a takeover bid occurs, the manager has less to lose by choosing $\mathrm{P} 2$ over $\mathrm{P} 1$ and may have something significant to gain: the preservation of her private benefits of control. Consequently, $\mathrm{M}$ has a greater incentive to choose $\mathrm{P} 2$ in situations where other shareholders would prefer $\mathbf{P 1}$.

This observation immediately leads to the conclusion that under a shareholder choice rule, whenever $\sigma<1$ the manager will choose to pursue project $P 2$ in more circumstances than the shareholders would prefer; i.e., the manager may select $P 2$ even when doing so reduces value for nonmanagerial shareholders.

This result is relatively simple to explain. Under a shareholder choice regime, managers prospectively fear the loss of their private benefits of control. Because such managers are not able to exercise a veto right at the time of the tender offer, they use the one tool available to them for avoiding it-the choice of P2 over P1. Even if P2 does not yield significant gains to the firm (or even imposes losses), it is valuable to the manager in a shareholder choice regime because it imposes costs on the firm's acquirers.

\section{Incentive Pay Under Shareholder Choice}

Recognizing the added agency cost imposed by a shareholder choice regime, shareholders can choose to respond in one of two ways. First, shareholders could simply live with the manager's wasteful attraction to $\mathrm{P} 2$ and set $\mathrm{M}$ 's compensation assuming she will choose that project. Alternatively, shareholders could attempt to increase $M$ 's incentive compensation to induce her to select what they view as the optimal project. Depending on the characteristics of P2, shareholders might opt for either of these strategies. By inspection of the above expressions, however, it is clear that the only way to fully align M's incentives with that of the shareholders' for every possible combination of $c$ and $\Delta$ is to set $\sigma=1$, effectively giving the entire firm to the manager-a strategy they would clearly never choose. Regardless of which strategy shareholders take, then, there are situations in which a shareholder choice regime makes nonmanagerial shareholders worse off than they would be under a managerial choice regime. This reasoning leads to our last result that under a shareholder choice regime, so 
long as $\mathrm{C}$ is sufficiently small, there is a range of values for $\Delta$ within which nonmanagerial shareholders would prefer the managerial choice rule over the shareholder choice rule.

The above result formalizes our central argument in this Article. Even if one assumes that shareholders are fully equipped and coordinated to evaluate and act upon a tender offer, a shareholder choice regime need not make shareholders better off (and may make them worse off) after controlling for the up-front managerial decisions that $M$ makes. On the one hand, shareholder choice allows existing shareholders to capture the entire takeover premium without being forced to split it with incumbent management. A shareholder choice rule can tempt $M$ to select projects that specifically prevent takeover bids from materializing, particularly when the value of $c$ is relatively small and the divide between managerial and shareholder incentives is the greatest. To be sure, shareholders could attempt to stem this added incentive problem by increasing $M$ 's share compensation $(\sigma)$. But, so doing requires shareholders to surrender value to $M$ regardless of whether a takeover ever occurs. Such a loss can easily eclipse any speculative gain shareholders would enjoy in the more remote circumstance of a takeover bid.

Of course, the result stated above does not suggest that shareholder choice is systematically worse than managerial choice. To the contrary, either regime may be optimal, depending on the relative values of $c$ and $\Delta$. This, however, is precisely our point: while some firms may flourish ex ante under a shareholder choice regime, others would be better off under a managerial choice rule. The likely variety of circumstances that firms may face renders a blanket rule of shareholder choice (or, for that matter, managerial choice) inappropriate.

\section{E. Numerical Example}

In order to clarify the formal results described above, it is useful to illustrate them through a concrete example. Consider a specific case of the framework just described in which $V_{H}=\$ 1$ million should $\mathrm{M}$ choose the status quo project (P1). On the other hand, should $M$ select the pre-bid embedded defense (P2), the value of the high payoff for the firm is given by $V_{H}=\Delta=\$ 1.04$ million; however, because of the defensive measure the firm loses all its value in the event that it is acquired, and thus $c=0$. Note that because P2 entails a higher upside under incumbent management, but a lower downside in the event of a takeover, it is not altogether obvious which of the two projects would be preferred by shareholders. Nevertheless, it turns 
out that, in this case, nonmanagerial shareholders would always prefer P1, a preference that is largely the artifact of the preclusive nature of $\mathrm{P} 2$. $^{162}$ Indeed, in this example, the choice of $\mathrm{P} 2$ is particularly severe because the manager is able to deter all takeovers (an admittedly extreme case, but one that underscores our point).

The Table below presents the basic structure of the optimal contract and the parties' behavior within each legal regime. Under a managerial choice rule, $M$ always picks the efficient project from the nonmanagerial shareholders' perspective because she can deter hostile offers without using $\mathrm{P} 2$.

Under shareholder choice, however, this need not be so, as demonstrated above. In that case, the negative repercussions of choosing $\mathrm{P} 2$ are so severe that the shareholders find it worthwhile to provide $M$ with an incentive to avoid the pre-bid embedded defense. So doing, however, requires that $M$ be paid a significant number of shares as part of her compensation package. Indeed, under a shareholder choice regime, $M$ receives $65.7 \%$ of the firm in incentive pay, while under managerial choice, she receives only $48.5 \%$. While shareholder choice gives the firm a larger capitalized value than managerial choice ( $\$ 392,170$ compared to $\$ 269,480$ ), a significantly smaller fraction of these rents actually go to the nonmanagerial shareholders. In fact, the nonmanagerial shareholders have to compensate $\mathbf{M}$ so heavily in a shareholder choice environment that they are left holding a smaller undiluted amount $(\$ 134,270)$ than they would enjoy in a managerial choice world $(\$ 138,720)$, where the manager would have a more moderate incentive contract.

Table 6. Numerical Simulation

\begin{tabular}{|l|c|c|c|c|c|}
\hline & $\begin{array}{c}\text { M's share } \\
(\sigma)\end{array}$ & $\begin{array}{c}\text { Pref. } \\
\text { Project }\end{array}$ & $\begin{array}{c}\text { Firm } \\
\text { Val. }\end{array}$ & $\begin{array}{c}\text { Non-Mgr. } \\
\text { SH Val. }\end{array}$ & $\begin{array}{c}\text { M's } \\
\text { Payoff }\end{array}$ \\
\hline $\begin{array}{l}\text { Mgr. } \\
\text { Choice }\end{array}$ & $48.5 \%$ & P1 & $\$ 269,480$ & $\$ 138,720$ & $\$ 343,060$ \\
\hline $\begin{array}{l}\text { SH } \\
\text { Choice }\end{array}$ & $65.7 \%$ & P1 & $\$ 392,170$ & $\$ 134,270$ & $\$ 372,440$ \\
\hline
\end{tabular}

${ }^{162}$ Explicitly, using the payoffs for non-managerial shareholders given in Tables 4 5 , it is possible to determine that non-managerial shareholders would favor Pl regardless of $\mathrm{M}^{\prime}$ s wage so long as $\Delta$ is less than approximately $\$ 1.048$ million. 
A few features of the table above are worth emphasizing. First, note that the manager receives a relatively greater share of compensation under the shareholder choice rule. While a bit surprising, this ordering is not merely coincidental. Indeed, within our framework, the manager generally receives at least as much incentive pay in a shareholder choice regime as she does in a managerial choice regime. The intuition behind this ordering stems, in large part, from the fact that under a shareholder choice regime, the firm must provide additional incentives for managers to eschew pre-bid embedded defenses. ${ }^{163}$

Second, as noted above, although shareholder choice induces a higher capitalized value for the company in this example than does managerial choice, using such values can be misleading. Explicitly, if one constrains attention to undiluted share value enjoyed by nonmanagerial shareholders, shareholder choice makes them worse off than the status quo. This observation provides a cautionary note for those who would assess the efficiency of any legal regime based on share value alone. In this case, the increase in firm value under shareholder choice is largely diverted to the manager, leaving nonmanagerial stakeholders worse off. ${ }^{164}$

To be sure, the example explored above is a particularly stark one, chosen to highlight our arguments. Nevertheless, this Section demonstrates the reasonable possibility that shareholder choice proposals often have unintended effects when one considers distortions to ex ante behavior.

${ }^{163}$ Even when non-managerial shareholders are not willing to provide $M$ with incentives to avoid $\mathrm{P} 2$, they will still tend to compensate $M$ with relatively greater share ownership. Indeed, since the adoption of P2 makes a takeover less likely, it thereby makes it more important that the compensation package itself minimize the costs associated with private benefits of control.

${ }^{164}$ Although managers' power to adopt embedded defenses obviously hurts nonmanagerial shareholders, a defender might still argue that shareholder choice remains desirable since it maximizes the sum of all parties' expected payoffs (at least in this example). Yet while shareholder choice maximizes joint welfare in this example, it does not do so in all cases. More significantly, it is not clear that managerial rents should be accorded the same "welfare weight" as shareholder returns, particularly if the object of the manager's contract is to serve shareholder interests. Finally, the very debate over shareholder choice has centered on the claim that the interests of non-managerial shareholders themselves are served by allocating them greater discretion over takeovers. Our analysis demonstrates why this claim may frequently fail. 


\section{INTERMEDIATE REGIMES}

The previous two Sections demonstrated that, under plausible circumstances, shareholder choice may be inferior to managerial choice. To illustrate this claim, our analysis drew on a particularly strong form of shareholder choice, in which shareholders hold the ultimate authority to accept or reject any takeover bid, as well as any post-bid or targeted defense. This Section briefly considers the possibility that some intermediate or hybrid regime might be preferable to either of these extremes, focusing on three types of intermediate regimes.

\section{A. Categorical Regulation of Defenses}

Some commentators have proposed ontological shareholder choice regimes that turn on how managers deter hostile offers. Under such regimes, courts could invalidate only certain identified defensive measures, leaving managers free to use others that may appear to be less harmful to nonmanagerial shareholders. While such approaches may hold some promise, their effectiveness hinges on the ease with which managers can substitute between substantially equivalent defenses. When such substitution is possible, this form of shareholder choice does little to reduce either managers' control over tender offers or their ability to appropriate private benefits.

Consider, for example, a rule under which courts invalidate pure defenses and those that managers undertake after a bid has been made. ${ }^{165}$ Under this rule, managers would not adopt blanket defenses, but only because they could instead employ targeted pre-bid embedded defenses. Thus, such a rule would do little to facilitate hostile acquisitions since managers could retain their power over hostile acquisitions by shifting to the use of targeted pre-bid embedded defenses as entrenchment devices.

Alternatively, courts could adopt a rule granting shareholders authority to overrule any pure or targeted defense post-bid, regardless of

${ }^{165}$ Professors Easterbrook and Fischel propose a rule requiring managerial passivity in the face of a tender offer. Easterbrook \& Fischel, supra note 40, at 1203 (suggesting that actions taken after an offer should be presumed invalid by courts as having been made in order to defeat the offer). To the extent that this rule only regulates post-bid defenses, it would have little effect on managerial control over tender offers as managers could simply adopt pure defenses pre-bid. Interpreting their passivity to invalidate managers' use of pre-bid pure defenses to retain control over takeovers we eliminate this problem, but would not eliminate managerial control over takeovers for the reasons given above. See also supra Part II.B (discussing targeted pre-bid embedded defenses). 
when it is adopted. To the extent shareholders credibly use this power to overrule defenses for any tender offer that maximizes shareholder value, this regime would effectively replicate the shareholder choice rule studied above, providing managers with an incentive to implement pre-bid blanket embedded defenses. We are therefore rather pessimistic that such a hybrid regime would prove any more effective than the regime studied above. Moreover, ex post shareholder authority over targeted pre-bid embedded defenses would undermine companies' ability to use such measures when they are value enhancing. ${ }^{160}$

Similar problems would plague a rule requiring ex ante shareholder approval of those pre-bid embedded defenses most directly targeted at hostile acquisitions. Should shareholders use this authority to invalidate the most targeted pre-bid defenses, managers could simply employ substitute untargeted defenses, which impose even greater costs on the firm. ${ }^{167}$ Moreover, it is more likely that shareholders would be unable to use this authority to regulate targeted pre-bid embedded defenses through ex ante voting because, when voting on ordinary business transactions, shareholders do not have sufficient incentives to obtain the information necessary to exercise their franchise effectively. Indeed, shareholders' current willingness to approve "shark repellent" defenses-such as fair price amendments and dual class stock-suggest that regulating such defenses through prebid shareholder approval may not be particularly effective. ${ }^{168}$

Finally, courts could target blanket pre-bid embedded defenses by prohibiting (or requiring ex ante shareholder approval for) all day-today business transactions that impose sufficient costs on potential acquirers to deter bids, regardless of their ex ante effect on firm value. In terms of the previous Section's model, this would mean allowing courts (and/or shareholders) to invalidate any defensive measure for which the value of $c$ is sufficiently low. Prudently executed, such a

${ }^{160}$ See supra note 60 (discussing the European Union's proposed break through rule).

${ }^{167}$ See Black \& Kraakman, supra note 38, at 561 (arguing that Delaware should require ex ante approval for a greater range of transactions that could be employed as takeover defenses).

${ }^{168}$ See Gilson, supra note 22, at $822-27$ (discussing the problems with pre-bid shareholder decision making that result in shareholders approving "shark repellant" antitakeover amendments that reduce shareholder value); Supra Part II.B.1 (discussing courts' problems regulating targeted defenses requiring shareholder approval); see also supra Part I.D.1 (discussing the unregulability of pre-bid embedded defenses). 
regime might be able to stem some of the moral hazard problems that we identify above. Yet, there are two problems with such a regime.

First, as discussed above, neither courts nor shareholders can effectively regulate ordinary business decisions. Thus, it is far from clear that either courts or shareholders can assess the costs of an embedded measure (in the form of $c$ ) any better than they can assess the firmspecific benefits of an embedded defense (in the form of $\Delta$ ). Indeed, both assessments require one to consider abstract, prospective effects of a particular business plan. This calculus would be particularly difficult - and the negative effects on contracting parties especially greatif managers respond to oversight by including defenses in a variety of contracts that impose small costs individually, but large costs in the aggregate. $^{169}$

Second, even if shareholders or courts could prohibit all high cost (low $c$ ) measures, it is far from clear that it would be optimal for them to do so. Embedded measures that impose high costs on acquisitions do not necessarily reduce shareholder welfare. A measure that imposes high costs on acquisitions may also provide the firm with high ex ante benefits, in the form of a superior contract with a third party who is particularly vulnerable to a change of control. ${ }^{170}$ Moreover, the ostensibly costly measure may impose little ex ante cost on shareholders in those circumstances where the ex ante probability of an acquisition occurring absent the measure is already quite low. Accordingly, it is difficult to determine whether regulating such "high cost" arrangements would be efficient without having a much better sense of the effect of such measures on ex ante firm value. Without knowledge

${ }^{169}$ See supra Part II.C.2 (discussing problems with ex ante shareholder regulation of penalty change of control provisions) \& note 119 (discussing why shareholders approve value-reducing shark repellents). Regulating such contracts would be particularly likely to decrease firm value because third parties could not tell, by looking at their own contracts, the likelihood that the court would invalidate the potentially defensive term.

${ }^{170}$ Indeed, there are plausible reasons why blanket embedded measures that impose high costs on the firm ex post also could provide high benefits ex ante. As previously discussed, many firms employ blanket embedded measures for legitimate (nondefensive) purposes. High penalties often are imposed on the target in such transactions in order to compensate those third parties who are particularly vulnerable to injury in the event of a change of control. Thus, the welfare of many firms might be lower under a rule that prohibits clauses that grant third parties substantial compensation in the event of a change of control. See supra Part II.C.1 (discussing the legitimate uses of penalty change of control provisions); see also text accompanying notes 97-100 (discussing the Donna Karan change of control provision). 
about the likely benefits from pre-bid embedded defenses, courts would have little hope of formulating and executing a prudent policy.

\section{B. Strategic Uncertainty Regarding Managerial Authority}

Perhaps ironically, one promising hybrid of shareholder choice may come in a retreat from the doctrinal certainty that many choice proponents (and legal scholars more generally) usually favor. It may be possible both to reduce agency costs and to deter managers from substituting untargeted embedded defenses through a regime in which courts invalidate some, but not all, managerial defenses, deliberately obscuring the types of defenses that are challengeable. ${ }^{17}$

While legal ambiguity may seem unwise at first blush, it may give courts a way to award shareholders a partial ability to combat managerial resistance. Managers who are uncertain whether a specific targeted defense will ultimately be upheld may continue to favor targeted defenses over untargeted ones, in order to obtain the potential benefit of a friendly deal. Yet, recognition that their targeted defenses may not be upheld may both reduce their appetite for private benefits (as these also tend to induce bids), while also making them more willing to negotiate with would-be acquirers. ${ }^{172}$

For instance, consider a version of the example from the previous Section, in which there is some uncertainty about whether the ultimate rule will favor managerial choice or shareholder choice. Suppose that there is a $75 \%$ chance that a court will allow managers to veto a bid and a $25 \%$ chance that shareholders will ultimately be allowed to accept a bid. In this example, the manager is less tempted (relative to shareholder choice) to select an inefficient untargeted defense (P2) because she is still relatively likely to be given freedom to select among bidders. Consequently, shareholders do not need to grant increased incentive compensation in order to deter the use of value-reducing blanket defenses: indeed, the optimal contract in this example would award the manager a $43.6 \%$ share of the firm (down from $48.5 \%$ under a managerial veto and $65.7 \%$ under a shareholder choice regime). More importantly, nonmanagerial shareholders

${ }^{171}$ For a discussion of other reasons why Delaware courts may favor vague laws see Ehud Kamar, A Regulatory Competition Theory of Indeterminacy in Corporate Law, 98 COLUM. L. REV. 1908 (1998).

${ }^{172}$ For another analysis of how legal uncertainty can augment allocational efficiency through bargaining, see Ian Ayres \& Eric Talley, Solomonic Bargaining: Dividing a Legal Entitlement to Facilitate Coasean Trade, 104 YALE L.J. 1027 (1995). 
would expect a payoff of $\$ 147,290$ under this intermediate regime, up considerably from $\$ 138,720$ under the managerial choice rule and $\$ 134,270$ under shareholder choice. ${ }^{173}$ On the whole, then, in this example this type of intermediate regime would increase shareholders' value above either of the two extreme cases. Our analysis therefore suggests that at least some types of intermediates (such as that represented by indeterminate law) may have a stronger attraction than has hitherto been recognized. ${ }^{174}$

\section{EMPIRICAL FIT}

Before concluding, it is useful to situate our argument within the growing empirical literature on corporate governance. So doing allows us to gauge the "fit" of our claims as a practical matter. Many of the points we have made above have some support in the available empirical data, and may even offer alternative explanations for phenomena that legal and finance scholars have found curious.

\section{A. Shareholder Attitudes Toward Managerial Choice}

Although it is not possible to test our claims directly, empirical analysis of shareholders' attitudes towards governance devices provides indirect evidence on whether shareholders expect to benefit from broad adoption of shareholder choice. If strong-form shareholder choice proponents were obviously correct in their claims, one would expect shareholders of many, if not most, firms to support such proposals. Their support would be manifest on numerous dimensions, including: (1) widespread resistance to tender offer defenses in IPO charters; (2) support for charter provisions restricting a board's ability to adopt the poison pill (or requiring boards to redeem the pill if shareholders support a bidder); and (3) support for shareholder

${ }^{179}$ Managers, on the other hand, would fare worse under this regime, expecting a payoff of $\$ 312,160$ (down from $\$ 343,060$ and $\$ 372,440$, respectively).

${ }^{174}$ Thus, empirical evidence that certain antitakeover statutes may lower firm value relative to that under Delaware law is not inconsistent with our analysis. See Daines, supra note 136, at 546-47 (finding that firms incorporated in states with stronger antitakeover statutes than Delaware have lower value than those incorporated in Delaware). We argue that a strong shareholder choice may reduce firm value relative to firm value under either Delaware's managerial veto rule or particular intermediate regimes. Yet our results do not suggest that a stronger managerial choice regime than Delaware's would enhance firm value. To the contrary, the analysis above suggests that weakening Delaware's regime by making managerial authority less certain could increase firm value. 
proposals seeking to declassify boards of existing firms. Moreover, one would expect the percentage of firms that limit board power over tender offers to have increased over time with the rise of institutional investors.

Yet, in contrast to the claims of shareholder choice proponentsbut consistent with our analysis-investors have displayed a tepid response to each of these shareholder choice proposals at the individual firm level. Indeed, not only does the existing evidence fail to demonstrate a consistent, growing pressure for shareholder choice, much of it shows exactly the opposite.

For example, a study of over 300 IPOs between 1994 and 1997 found that a majority of IPO firms explicitly included antitakeover provisions in their charters. ${ }^{175}$ Indeed, over sixty percent of the IPO firms had charters that specifically strengthened the poison pill by either establishing a staggered board or by making it difficult for shareholders to replace the board between annual meetings. ${ }^{176}$ No firm included a provision to either limit board authority to adopt antitakeover provisions in the future or to prohibit or limit the use of poison pills. ${ }^{177}$

Moreover, the proportion of firms going public with staggered boards appears to have increased over time. A later study found that the percentage of firms going public with staggered boards increased from thirty-four percent in the early 1990s to eighty-two percent in 1999. ${ }^{178}$ This increased use of a staggered board occurred over the very period in which shareholders came to understand the tremendous power of a staggered board as a defensive mechanism. ${ }^{179}$ This data on IPOs is consistent with our analysis.

${ }^{175}$ Daines \& Klausner, supra note 25 , at 85 (“[R]oughly two-thirds of the firms in our sample have [antitakeover provisions] that can pose a significant impediment to a hostile acquisition, and about half have adopted the strongest [provisions]."); see also Laura Casares Field \& Jonathan M. Karpoff, Takeover Defenses of IPO Firms, 57 J. FIN. 1857,1858 (2002) (finding that fifty-three percent of industrial firms going public from 1988 to 1992 employed at least one antitakeover defense).

${ }^{176}$ Kahan \& Rock, supra note 29, at 885 (reporting results obtained from Robert Daines' and Michael Klausner's data on antitakeover provisions).

${ }^{177}$ Daines \& Klausner, supra note 25, at 95. These results are consistent with those obtained by Coates, supra note 116 , at 1353, 1375-77.

${ }^{178}$ Coates, supra note 116 , at 1376.

${ }^{179}$ See, e.g., Kahan \& Rock, supra note 29, at 911 (reporting on increase in shareholder opposition to staggered boards); Lynn A. Stout, Do Antitakeover Defenses Decrease Shareholder Wealth? The Ex Post/Ex Ante Valuation Problem, 55 STAN. L. REv. 845, 853 (2002) (citing studies showing that, during the late 1990s, between forty-four percent and eighty-two percent of IPO charters included staggered board provisions); see also 
Another piece of evidence comes from examining how (and whether) shareholders actively campaign for shareholder choice. Notwithstanding the rise of institutional investors, shareholders of existing publicly held firms have not campaigned vigorously either to limit control over tender offer defenses or to restrict boards' use of the poison pill. Despite early interest in precatory shareholder resolutions seeking to control boards' use of the pill, since 1996 the number of such resolutions has declined to an average of less than ten to fifteen per year. Moreover, these resolutions generally fail (although they have garnered more shareholder votes than previously). ${ }^{180}$ Institutional shareholders-including state pension funds-also have not used their considerable political power to advocate for legislative adoption of shareholder choice regimes.

There are many competing explanations for this lack of shareholder interest in more direct shareholder governance. One possibility is that the conventional arguments favoring managerial choice are right: post-bid, shareholders benefit from managerial control over the bidding process. ${ }^{181}$ Another possible explanation may be found in deficiencies and/or inertia in the IPO market and in the bidding process itself. ${ }^{182}$

Bebchuk, Coates \& Subramanian, supra note 6, at 925 (showing the increased likelihood that a company with a staggered board will remain independent when faced with a hostile bid for acquisition).

${ }^{180}$ Kahan \& Rock, supra note 29, at 885-86. Shareholders of existing firms have started to attempt to limit the use of one defense-staggered boards-by resisting charter amendments to establish staggered boards and voting in increasing numbers for shareholder resolutions seeking to declassify existing classified boards. Id. at 88687. This, however, is far from a general move to establish shareholder choice. Shareholders have not similarly moved to restrict boards' ability to adopt poison pills. Moreover, these anti-staggered board efforts have not been part of a general movement, but have been targeted at particular firms. Id at 886 n.76. Moreover, they have either failed or have prevailed only in a precatory form. Id. at $887 \mathrm{nn.77-78.}$

${ }^{181}$ E.g., Kahan \& Rock, supra note 29, at 897-99 (concluding that shareholders may find more value in "complex takeover regime[s]" than in increasing their own control).

${ }^{182}$ Recently, Lucian Bebchuk has offered alternative potential explanations for shareholders' apparent disinterest in voluntarily adopting shareholder choice. Relying on efficiency-based, agency-based, and information-based explanations, he shows that when managers have private information about firm value and when private benefits to managers are positively correlated with firm value, then firms going public might not offer a charter provision restricting defenses even though such a provision would be optimal. Bebchuk, supra note 81 , at $730-43$. This result turns on the firms being unable to signal firm value through mechanisms other than the charter provision of takeovers, and on the assumption that private benefits are positively correlated with firm value. 
Our analysis presents an additional explanation, however: shareholders recognize that shareholder choice could reduce their welfare by inducing managers to implement value-reducing blanket defenses, thereby forcing shareholders to suffer the cost of either decreased acquisitions or substantially increased managerial incentive pay. Thus, our analysis suggests that shareholders may accept poison pills and classified boards because they recognize that they cannot, in fact, preclude the use of defensive measures. Consequently, they would prefer to accept the relatively modest costs associated with these targeted measures in order to avoid the greater evil of the alternative blanket defenses managers might otherwise employ.

Viewed in this light, shareholders' apparent disinterest in campaigning aggressively for shareholder choice may not be a product of collective action problems, lack of information, or failures of the IPO markets. Rather, it may simply represent an informed choice given an accurate assessment of the options available to them and the limited potential domain of shareholder choice. As the defenses shareholders can regulate are, ultimately, less destructive of firm value than other blanket defenses managers might employ, shareholders may live with these defenses (including "just say no") for fear that the alternative would be worse.

\section{B. Evidence on Defenses and Executive Compensation}

Additional evidence exists to support our claim. If managers can implement substitute value-reducing defenses, our analysis reveals that greater shareholder control over tender offers could potentially lead to one of two phenomena: (1) managers would routinely adopt these defenses, or (2) shareholders would deter them from doing so by increasing managers' ownership share in the firm. In any event, our model predicts that managers' share of ownership should be higher on average under shareholder choice regimes, in part to deter them from employing untargeted defenses.

The conclusion that managers' share of ownership should be higher when there are few antitakeover devices is contrary to a more classic agency cost view. Under this view, firms are more likely to utilize incentive compensation when managers are insulated by antitakeover devices from the market for corporate control, on the theory that firms employ incentive compensation to mute agency costs 
heightened by the lack of an active market for corporate control. ${ }^{189}$ By contrast, our theory predicts that firms are less likely to employ incentive pay when managers are insulated by pure defenses from hostile acquisitions because these defenses help align managers' incentives with those of shareholders as to the value of friendly deals.

Empirical analysis of the relationship between antitakeover devices and incentive compensation suggests that, consistent with our analysis, the lower the managers' ability to use traditional antitakeover defenses, the higher their incentive pay. Consider, for example, the following correlation matrix, drawn from a data set pairing executive compensation data with corporate governance data of 1,200 publicly traded firms in the year 2000 . The variable in the first row and column is (1) the percentage of outstanding shares owned by the firm's highest paid executive (usually the CEO) and represents a measure of incentive pay. The remaining variables designate the existence of (2) blank check preferred stock; (3) classified boards; (4) a poison pill provision in the firm's bylaws; (5) the cross product of classified boards and poison pills; and (6) the existence of change of control provisions in executive stock options. Variables (2) through (6) are all measures of how resistant a corporation is to hostile bids.

${ }^{183}$ E.g., Kahan \& Rock, supra note 29, at 898 (suggesting that firms responded to the rise of takeover defenses by implementing adaptive defenses, such as executive compensation, to align managers' incentives with those of shareholders). 


\section{Table 7. Executive Share Ownership vs. Corporate Governance Indicia ${ }^{18}$}

\begin{tabular}{|c|c|c|c|c|c|c|}
\hline & \% Shrs (CEO) & Blank Check & Class. Bd & Pois. Pill & $(\mathrm{Cl} . \mathrm{Bd}) \mathbf{x}(\mathrm{PP})$ & $\mathrm{CoC}$ (Options) \\
\hline \% Shrs (CEO) & 1.0000 & & & & & \\
\hline \multirow[t]{2}{*}{ Blank Check } & -0.1132 & 1.0000 & & & & \\
\hline & 0.0114 & & & & & \\
\hline \multirow[t]{2}{*}{ Class. Bd } & -0.0008 & 0.1056 & 1.0000 & & & \\
\hline & 0.9863 & 0.0002 & & & & \\
\hline \multirow[t]{2}{*}{ Pois. Pill } & -0.2978 & 0.1394 & 0.2535 & 1.0000 & & \\
\hline & 0.0000 & 0.0000 & 0.0000 & & & \\
\hline \multirow[t]{2}{*}{$(\mathrm{Cl} . \mathrm{Bd}) \times(\mathrm{PP})$} & -0.1985 & 0.1467 & 0.6701 & 0.7153 & 1.0000 & \\
\hline & 0.0000 & 0.0000 & 0.0000 & 0.0000 & & \\
\hline \multirow[t]{2}{*}{ CoC (Options) } & -0.2599 & 0.0572 & 0.1801 & 0.2994 & 0.2493 & 1.0000 \\
\hline & 0.0000 & 0.0474 & 0.0000 & 0.0000 & 0.0000 & \\
\hline
\end{tabular}

Note that every antitakeover provision in Table 7 is positively correlated with every other one at least at a ninety-five percent confidence level, suggesting that such provisions are often complements rather than substitutes for one another. What is more striking, however, is the negative correlation that each of these variables has with executive share ownership. Indeed, every single antitakeover protection is negatively correlated with share percentage and, all but one (classified boards), are statistically significant. ${ }^{185}$ Moreover, the economic magnitudes of many of these correlations appear to be moderately high. From an aggregate perspective, then, managerial incentive compensation appears to grow when managers' ability to employ targeted defenses shrinks. ${ }^{186}$

${ }^{184}$ IRRC database, supra note 74 (compiling governance data for 2000); Standard \& Poor's, Compustat, at http://www.compustat.com/www (n.d.) (compiling executive compensation data for 2000 from database). Correlations were done on a pair-wise basis with $\mathbf{P}$-values in italics.

${ }^{18 \overline{5}}$ Our data codes for classified boards of all types, as opposed to the "effective classified boards" examined in Bebchuk, Coates \& Subramanian, supra note 6 (defining "effective" classified boards as those where the board is classified in the certificate and the certificate limits the number of directors and restricts shareholders' ability to act through written consent).

${ }^{186}$ A simple correlational analysis, of course, leaves open the question of which way causation is likely to run. While the results above are consistent with our analysis, it is also the case that managers who own a lot of shares have less need to seek tender offer defenses. We plan to examine this relationship in more detail in future scholarship. 
Also consistent with our conclusion, another recent study found that incentive pay is both positively related to the presence of independent directors and inversely related to leverage financing. ${ }^{187}$ Both of these tendencies seem to cut against the conventional, operational agency cost story, and toward our "tender offer defenses" agency cost story. The relationship between incentive pay and independent directors is consistent with our analysis to the extent that independent directors make it more difficult for managers to deter value-enhancing hostile acquisitions and appropriate private benefits from friendly acquisitions. In this case, managers of firms with independent directors may be more inclined to employ embedded defenses if concerned they cannot later employ targeted defenses to deter hostile deals. ${ }^{188}$ Increasing their incentive pay may deter this form of agency cost. Although this is but a sampling of how our framework might be tested empirically, it nonetheless suggests that the analytical arguments presented above may help explain behavior in publicly traded companies.

\section{CONCLUSION}

Delaware's embrace of a "just say no" defense grants managers considerable ability to insulate themselves from the disciplining effect of the market for corporate control. This almost certainly results in managers misappropriating far greater private benefits-and providing shareholders less value-than they would if subject to a wellfunctioning takeover market.

Proponents of shareholder choice argue that the solution to this problem is for the courts to insist that shareholders exercise ultimate authority over whether an acquisition should proceed. ${ }^{189}$ Such judicial insistence would permit shareholders to voice their preferences about the very hostile acquisitions most likely to increase shareholder welfare and discipline management.

In this Article, we have demonstrated that while such arguments for shareholder choice have considerable merit, they are not enough to win the day. Conventional justifications of shareholder choice

${ }^{187}$ Harvey \& Shrieves, supra note 27, at 511.

${ }^{188}$ Indeed, it seems likely that independent directors are comparatively inept at deterring embedded, pre-bid defenses, since they frequently have little direct familiarity with the operational decisions of the company (within which such defenses are hidden).

${ }^{189}$ See supra Part I.B (discussing shareholder choice proposals). 
generally presume that managers will not change their behavior in the face of a reduction in their historical discretion. ${ }^{190}$ There is no reason to expect this to be the case. Indeed, the history of acquisitions and tender offer defenses is literally littered with examples in which managers creatively invent new defenses to meet new threats to their control.

A complete analysis of shareholder choice, therefore, requires that we recognize that managers will act in their own self interests and seek ways to deter either hostile bids in particular, or friendly and hostile bids generally. Specifically, managers faced with a shareholder choice regime will likely turn to embedded defenses adopted long before a tender offer, as these are the defenses courts would be least able to regulate without doing injury to the foundational premise that publicly held firms should be managed by professional managers, not shareholders (or courts).

In examining existing business practices, this Article has revealed a host of ostensibly legitimate arrangements that can simultaneously deter takeovers. Such arrangements include blank check preferred stock, management contracts, and change of control provisions in third-party contracts. Moreover, these arrangements are sufficiently varied and flexible that one must assume that managers-if sufficiently motivated by a fear of hostile takeovers-could devise a variety of other pre-bid arrangements which could operate as a serious impediment to bids.

Examining the risk that managers would adopt such measures in response to shareholder choice, this Article shows that shareholder choice would make managers willing to employ value-reducing blanket embedded defenses that they would not adopt under a managerial choice rule. Managers subject to shareholder choice would have much to gain from such defenses as they would help block hostile deals. They also would have less to lose because shareholder choice would squeeze out the friendly deals managers would otherwise seek to protect. Accordingly, in order to retain their private benefits, managers subject to shareholder choice would be more likely to adopt blanket defenses that deter all acquisitions, or at least credibly threaten to do so. In either case, shareholder choice can reduce the expected payoff of nonmanagerial shareholders.

Consequently, shareholders' apparent disinterest in campaigning aggressively for shareholder choice may not be a product of collective 
action problems, lack of information, or failures of the IPO markets. Rather, shareholders may fail to insist on shareholder choice because they recognize that it is not practically available to them under a regime of professional managerial control of day-to-day business decisions. Under this regime, shareholders could block certain defenses, but not all defenses. Because the defenses shareholders can block-such as the poison pill-are, in the end, less destructive of firm value than other blanket defenses managers might employ, shareholders may live with the pill (and "just say no") for fear that the alternative would be worse.

This is not to say that shareholder choice is invariably inferior to managerial choice. But the case for shareholder choice must depend on more than a partial equilibrium claim that shareholders may be better able to evaluate tender offers than managers. Rather, the case for shareholder choice must depend on a full comparison of the two regimes as they would actually be implemented. In particular, we must consider shareholder choice recognizing that courts cannot regulate all defenses, and that managers will adapt and seek out defenses in these zones beyond court regulation. Only if shareholder choice is superior under such circumstances should we ultimately be willing to embrace it. 